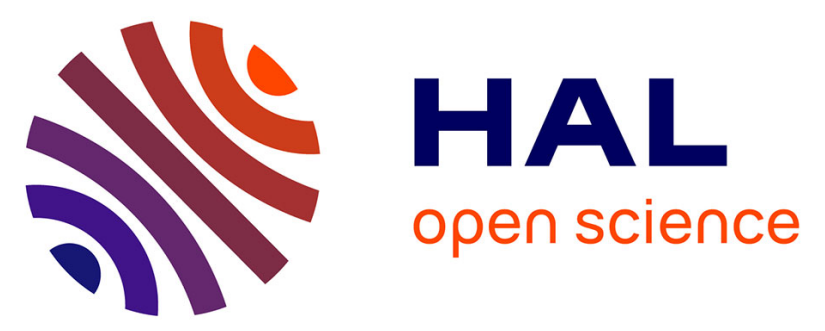

\title{
Theoretical crystal structure prediction of aminosalicylic acid: Charge density topological and electrostatic analyses
}

R. Meenashi, K. Selvaraju, A. David David Stephen, Christian Jelsch

\section{- To cite this version:}

R. Meenashi, K. Selvaraju, A. David David Stephen, Christian Jelsch. Theoretical crystal structure prediction of aminosalicylic acid: Charge density topological and electrostatic analyses. Journal of Molecular Structure, 2020, 1213, pp.128139. 10.1016/j.molstruc.2020.128139 . hal-03003730

\author{
HAL Id: hal-03003730 \\ https://hal.science/hal-03003730
}

Submitted on 13 Nov 2020

HAL is a multi-disciplinary open access archive for the deposit and dissemination of scientific research documents, whether they are published or not. The documents may come from teaching and research institutions in France or abroad, or from public or private research centers.
L'archive ouverte pluridisciplinaire HAL, est destinée au dépôt et à la diffusion de documents scientifiques de niveau recherche, publiés ou non, émanant des établissements d'enseignement et de recherche français ou étrangers, des laboratoires publics ou privés. 
Published in Journal of Molecular Structure, (2020) 128139.

DOI : 10.1016/j.molstruc.2020.128139

\title{
Theoretical crystal structure prediction of aminosalicylic acid: charge density topological and electrostatic analyses.
}

\author{
R. Meenashi ${ }^{\mathrm{a}}$, K. Selvaraju ${ }^{\mathrm{a}}$, A. David Stephen ${ }^{\mathrm{b}}$, Christian Jelsch \\ ${ }^{a}$ Department of Physics, Kandaswami Kandar's College, Velur, 638182, India \\ ${ }^{b}$ Department of Physics, Sri Shakthi institute of Engineering and Technology, Coimbatore, 641062, India \\ ${ }^{c} C R M 2$, Lorraine University, CNRS, $B P$ 70239, Vandoeuvre les Nancy, cedex, 54506, France
}

Correspondence email: physicsselvaraj@gmail.com

\section{Highlights}

- 31 Crystal packings of aminosalicylic acid were predicted

- Predicted structure with lowest energy is close to real structure

- Electrostatic properties and molecular interactions were compared

\begin{abstract}
The crystal structure prediction of the possible stable packings of pharmaceutical drug 4amino-2-hydroxybenzoic acid was initiated through ab initio methods. The lattice energy values of the hypothetical conformers of the molecule generated for the global search were minimized, employing the associated distributed multipolar electron density. The crystal packing with minimum global energy corresponds to the experimental crystal. The conformer generated from the valid minimization was subjected to Quantum Theory of Atoms In Molecules (QTAIM) analysis in order to improve insight on the chemical properties of the crystal on which the pharmaceutical activity depends. The electron density and the Laplacian of the electron density were analyzed in detail for the non-covalent interactions in the crystal. While the dimer formed by the $\mathrm{COOH} / \mathrm{COOH}$ homo-synthon has the strongest energy and is mostly electrostatic, other dimers formed in the crystal are mostly stabilized by dispersive forces. The complementarity of
\end{abstract}


the inner and exterior electrostatic potential on the Hirshfeld was analyzed in the different crystal packings generated.

Keywords: Aminosalicylic acid; Crystal Structure Prediction; QTAIM; Interaction energy; Intermolecular Interactions; Electrostatic potential. 


\section{Introduction}

The crystal structures of molecule are the uniform and multidimensional arrangement of the base atoms in the lattice point, generating a least energy thermodynamically stable phase $[1,2]$. As the pharmaceutical properties and the bioavailability depend on the crystal phase of the molecule, theoretical prediction of possible crystal structures gained importance. The prior aim of the current research is to analyze the predicted crystal lattices of Amino Salicylic Acid (AMSA) molecule and compare them with the experimental reported structure.

The AMSA compound (Fig. 1) is an oral antibiotic pharmaceutical drug used against tuberculosis [3]. It has also been used as a second line agent to sulfasalazine in people with ulcerative colitis and Crohn's disease $[4,5]$. The crystal structure prediction of the title compound explores the lattice energy surface to identify unknown possible polymorphic crystal structure. The arrangement of molecules in the crystal lattice guides the physical as well as chemical properties and thereby the pharmaceutical performance. As the shape and the size of the solid drugs can influence the dissolution rate, lyophilization and bioavailability, the crystal structure prediction for the stable crystal lattices of pharmaceutical drugs has gained importance.[6]<smiles>Nc1ccc(C(=O)O)c(O)c1</smiles>

Figure 1. Chemical structure of AMSA molecule

The prediction of crystal structure of the compound relevant to our study has one experimental crystal packing reported in the CCDC, corresponding to structures with codes AMSALA, AMSALA01 and AMSALA02 [7] successively determined. We have identified some other possible crystal packings from ab inito method and thus validate our prediction methodology with respect to the reported X-ray structure. 


\section{Materials and methods.}

\subsection{Crystal Structure Prediction}

The aim of the research was to identify the lowest energy conformers of AMSA molecule belonging to the possible common space groups listed in the crystal database. The molecular structure of the parent molecule was subjected to an initial gas phase optimization using the DFT [8] approach via B3LYP/6-31g(d) basis set operations using Gaussian 09 package [9]. The initial optimization validated the geometric structure of the parent molecule for the global search. The search for a dense crystal packing was performed in the common space groups P1, P-1, P2, Pm, $\mathrm{Pc}, \mathrm{P} 2{ }_{1}, \mathrm{P} 2 / \mathrm{c}, \mathrm{P} 2{ }_{1} / \mathrm{m}, \mathrm{P} 2 / \mathrm{m}, \mathrm{P} 2{ }_{1} / \mathrm{c}, \mathrm{Cc}, \mathrm{C} 2, \mathrm{C} 2 / \mathrm{c}, \mathrm{Pnn} 2, \mathrm{Pba} 2, \mathrm{Pnc} 2, \mathrm{P} 22_{1}, \mathrm{Pmn} 2{ }_{1}, \mathrm{Pma} 2, \mathrm{P} 2{ }_{1} 2_{1} 2_{1}$, $\mathrm{P} 22_{1} 2$, Pca2 1 , Pna2, Pnma and Pbca using the MOLPAK package [10]. The global search for dense crystal structures of AMSA were done by performing step-by-step orientations of the central parent molecule in all common coordination geometries and constructing the appropriate coordination patterns with unit cell volume as a function. The packings of the AMSA molecule within the threshold interactions of the neighboring fragments of the parent molecules were generated from $-90^{\circ}$ to $90^{\circ}$ rotation in $10^{\circ}$ steps. The orientation and the repetition of AMSA in the multidimensional grid generated $6859\left(19^{3}\right)$ hypothetical structures. The lattice energy of these starting structures was optimized by the PMIN [10] operation implementing the repulsion potential field alone as the inner lattice minimization. The hypothetical densest structures of AMSA molecule with minimum cell volume generated in the commonly encountered 31 space groups were subjected to inner lattice minimizations using the DMACRYS algorithm [11] incorporating a repulsion-dispersion potential field of the form (1)

$$
\text { (1) } U=\sum_{\mathrm{ie} 1 \mathrm{k} \epsilon 2}\left[\left(A_{\mathrm{ii}} A_{\mathrm{kk}}\right)^{1 / 2}\right] \exp \left[-1 / 2\left(B_{\mathrm{ii}}+B_{\mathrm{kk}}\right) R_{\mathrm{ik}}\right]-\left(C_{\mathrm{ii}} C_{\mathrm{kk}}\right)^{1 / 2} / R_{\mathrm{ik}}^{6}
$$

where $i$ and $k$ are the atoms in different types of molecules 1 and 2. The potential field incorporated in the lattice minimization was generated from the FIT potential, parameterized by Williams and Cox [12] with additional terms for the hydrogen atoms bound to nitrogen later fitted by Coombes et al. [13]. The discrepancy of the PMIN lattice minimization with repulsion alone potential was rectified in the inner lattice minimization, thereby confirming the accuracy. The electrostatic interactions along with intermolecular binding of the AMSA molecules were analyzed in detail from the set of multipoles generated from the GDMA [14] algorithm via MP2 level [15] charge density scrutiny through MP2/6-31G(d,p) basis set operation. The lattice 
minimized AMSA molecules attaining the Born criteria of mechanical stability [16] with valid eigenvalue representations were tabulated [Table 1] on the basis of energy ranking. The thermodynamic stability of the AMSA molecule was verified from the second derivative properties calculated from the $C_{\mathrm{ij}}$ elements of the Hessian matrix. In the current research, the invalid hypothetical structures generated with negative eigenvalues were subjected to reminimization by removing the non-zero representation from the symmetry constraints. The quantitative molecular electrostatic potential map for both experimental and predicted crystal structures was generated and visualized on the three dimensional surface using the program WFA-SAS [17].

\subsection{Bader analysis}

Topological analysis was carried out for the gas phase molecule lifted from the predicted global minimum structure via Bader Quantum Theory of Atom In Molecules (QTAIM) [18]. This approach tends to analyze the characteristics of chemical bonding (closed and open shell interactions) [19]. Single point calculations were carried out using Hybrid GGA Functional wB97X-D [20] (dispersion corrected) 6-311G $++(\mathrm{d}, \mathrm{P})$ basis set (triple zeta) over the asymmetric unit of AMSA and dimeric pairs in Gamess package [21]. For the QTAIM analysis, the wave function was obtained from the above calculations and analyzed using Multiwfn 3.3.9.[22]

\subsection{Electrostatic complementarity in the crystals.}

The charge density of the AMSA molecule was modeled using the multipolar atom of Hansen \& Coppens [23]. Pseudo-atom multipolar databases offer the possibility to reconstruct the molecular electron density, without the need of performing first principle calculations at each time. The electron density parameters were transferred from the experimental ELMAM2 database of multipolar atoms [24] which is issued from single crystal diffraction studies of peptides and small molecules at ultra-high resolution. After transfer, the number of valence electrons of all atoms was uniformly modified to ensure electroneutrality. The X-H bond lengths were elongated according to standard neutron diffraction distances [25]. The electrostatic potential $V$ was computed with the MoPro software on the Hirshfeld surface [26]. $V$ int was computed from the reference molecule while the external potential $V$ ext was generated from the ensemble of molecular neighbors in contact with the inner molecule. Hirshfeld surfaces and contact enrichment ratios were obtained with MoProViewer [27]. The electrostatic complementarity was assessed by analyzing the $V$ int and $V_{-}$ext values on the Hirshfeld surface. 


\section{Results}

\subsection{Predicted crystal structures}

Table 1. List of predicted possible stable crystal structures of AMSA molecule. The most stable packing and the experimental one are in bold.

\begin{tabular}{|c|c|c|c|c|c|c|c|c|c|}
\hline $\begin{array}{l}\text { Confor- } \\
\text { mers }\end{array}$ & ID & $\begin{array}{l}\text { Space } \\
\text { group }\end{array}$ & $\begin{array}{c}U_{\text {lattice }} \\
\mathrm{kJ} / \mathrm{mol}\end{array}$ & $a(\AA)$ & $b(\AA)$ & $c(\AA)$ & $\beta\left(^{\circ}\right)$ & $\begin{array}{c}\text { den- } \\
\text { sity } \\
\left(\mathrm{g} / \mathrm{cm}^{3}\right)\end{array}$ & $Z^{\prime}$ \\
\hline exp. & & $\mathrm{P} 2{ }_{1} / \mathrm{c}$ & -121.2 & $7.1371(3)$ & $3.7278(2)$ & $24.4465(12)$ & $94.386(2)$ & 1.57 & 1 \\
\hline $\begin{array}{l}\text { STR 1 } \\
\Delta / \exp \\
\end{array}$ & $\mathrm{FC}$ & $\mathrm{P} 2_{1} / \mathrm{c}$ & $\begin{array}{l}-131.7 \\
+8.7 \% \\
\end{array}$ & $\begin{array}{c}6.99 \\
-2.0 \% \\
\end{array}$ & $\begin{array}{c}3.67 \\
-1.6 \% \\
\end{array}$ & $\begin{array}{r}24.82 \\
+3.7 \% \\
\end{array}$ & $\begin{array}{r}90.94 \\
+3.6^{\circ} \\
\end{array}$ & \begin{tabular}{l|}
1.60 \\
$+1.8 \%$ \\
\end{tabular} & 1 \\
\hline STR 2 & $\mathrm{DC}$ & $\mathrm{C} 2 / \mathrm{c}$ & -131.4 & 13.81 & 3.59 & 26.76 & 103.06 & 1.58 & 1 \\
\hline STR 3 & $\mathrm{AU}$ & $\mathrm{Pna}_{1}$ & -126.5 & 16.29 & 3.72 & 10.95 & 90.00 & 1.53 & 1 \\
\hline STR 4 & FA & $\mathrm{P} 2{ }_{1} / \mathrm{n}$ & -125.6 & 7.25 & 26.44 & 3.61 & 71.78 & 1.55 & 1 \\
\hline STR 5 & AQ & $\mathrm{P} 2{ }_{1} 2_{1} 2_{1}$ & -124.5 & 13.49 & 13.19 & 3.64 & 90.00 & 1.57 & 1 \\
\hline STR 6 & AY & $\mathrm{Pca}_{1}$ & -124.2 & 16.59 & 3.63 & 11.02 & 90.00 & 1.53 & 1 \\
\hline STR 7 & DA & $\mathrm{Cc}$ & -123.3 & 3.58 & 16.83 & 11.03 & 90.82 & 1.53 & 1 \\
\hline STR 8 & $\mathrm{AH}$ & $\mathrm{P} 2{ }_{1}$ & -123.0 & 3.57 & 11.01 & 8.59 & 78.23 & 1.54 & 1 \\
\hline STR 9 & $\mathrm{AF}$ & $\mathrm{P} 2_{1}$ & -122.9 & 6.96 & 3.60 & 16.54 & 129.60 & 1.59 & 1 \\
\hline STR 10 & $\mathrm{AK}$ & $\mathrm{P} 2_{1} / \mathrm{c}$ & -122.8 & 12.82 & 3.73 & 14.16 & 102.68 & 1.54 & 1 \\
\hline STR 11 & AA & P1 & -120.8 & 3.58 & 7.00 & 7.11 & 84.94 & 1.55 & 1 \\
\hline STR 12 & $\mathrm{AV}$ & $\mathrm{Pna}_{1}$ & -119.1 & 15.23 & 12.16 & 3.69 & 90.00 & 1.49 & 1 \\
\hline STR 13 & $\mathrm{AM}$ & $\mathrm{P} 2{ }_{1} / \mathrm{c}$ & -118.4 & 7.12 & 7.11 & 13.37 & 99.48 & 1.52 & 1 \\
\hline STR 14 & $\mathrm{AZ}$ & $\mathrm{P} 2{ }_{1} 2_{1} 2_{1}$ & -117.6 & 25.31 & 3.64 & 6.99 & 90.00 & 1.58 & 1 \\
\hline STR 15 & $\mathrm{AB}$ & P-1 & -117.2 & 6.78 & 7.22 & 7.74 & 79.35 & 1.56 & 1 \\
\hline STR 16 & DB & $\mathrm{C} 2$ & -114.0 & 14.62 & 3.61 & 12.73 & 83.47 & 1.53 & 1 \\
\hline STR 17 & AS & $\mathrm{Pna}_{1}$ & -112.0 & 11.14 & 16.84 & 3.62 & 90.00 & 1.50 & 1 \\
\hline STR 18 & $\mathrm{CB}$ & Pbca & -111.5 & 16.47 & 11.96 & 6.82 & 90.00 & 1.51 & 1 \\
\hline STR 19 & AP & $\mathrm{P} 2{ }_{1} 2{ }_{1} 2$ & -111.2 & 7.37 & 25.34 & 3.66 & 90.00 & 1.49 & 1 \\
\hline STR 20 & BA & $\mathrm{P} 2{ }_{1} 2{ }_{1} 2$ & -111.2 & 25.34 & 7.35 & 3.66 & 90.00 & 1.49 & 1 \\
\hline STR 21 & $\mathrm{BB}$ & $\mathrm{P} 1$ & -111.1 & 25.33 & 7.37 & 3.66 & 90.00 & 1.49 & 1 \\
\hline STR 22 & $\mathrm{CD}$ & $\mathrm{P} 2_{1} / \mathrm{c}$ & -110.4 & 13.54 & 6.78 & 14.68 & 88.65 & 1.51 & 2 \\
\hline STR 23 & $\mathrm{AI}$ & $\mathrm{P} 21 / \mathrm{c}$ & -110.0 & 9.75 & 5.32 & 13.96 & 97.83 & 1.42 & 1 \\
\hline STR 24 & $\mathrm{BH}$ & $\mathrm{Pca}_{1}$ & -108.7 & 13.11 & 3.77 & 13.31 & 90.00 & 1.55 & 1 \\
\hline STR 25 & $\mathrm{BD}$ & $\mathrm{Pna}_{1}$ & -99.1 & 16.79 & 8.97 & 4.71 & 90.00 & 1.43 & 1 \\
\hline STR 26 & $\mathrm{DE}$ & $\mathrm{C} 2 / \mathrm{c}$ & -97.6 & 24.08 & 7.43 & 13.21 & 40.21 & 1.33 & 1 \\
\hline STR 27 & $\mathrm{CA}$ & P-1 & -96.9 & 8.02 & 6.86 & 6.96 & 75.05 & 1.51 & 1 \\
\hline STR 28 & $\mathrm{CE}$ & $\mathrm{P} 2{ }_{1} / \mathrm{b}$ & -94.1 & 15.52 & 8.59 & 11.31 & 88.82 & 1.35 & 2 \\
\hline STR 29 & $\mathrm{BF}$ & $\mathrm{Pm}$ & -93.8 & 8.42 & 22.39 & 3.73 & 89.32 & 1.45 & 2 \\
\hline STR 30 & $\mathrm{CC}$ & Pbca & -85.7 & 7.53 & 7.12 & 27.26 & 90.00 & 1.39 & 1 \\
\hline STR 31 & DD & $\mathrm{C} 2 / \mathrm{c}$ & -85.0 & 13.79 & 8.01 & 14.83 & 62.13 & 1.40 & 1 \\
\hline
\end{tabular}




\subsection{Global minimum}

In the detailed study of the structures from Table 1, the global minimum of the AMSA molecule generated at $-131.7 \mathrm{~kJ} / \mathrm{mol}$ with density of $1.60 \mathrm{~g} / \mathrm{cm}^{3}$. As the stability of the crystal structure indirectly depends on the energy associated, studies were carried out to justify the thermodynamic stable nature. The predicted global minimum of AMSA was found to be a monoclinic crystal system with $\mathrm{P} 2{ }_{1} / \mathrm{c}$ space group. The lattice parameters of the structure were compared with those of the experimental structure and the values were found in good agreement with a maximal deviation of $3.7 \%$ [Table 1]. The density of the predicted STR1 packing is only $1.8 \%$ larger than the experimental value. The generated lowest energy structure of AMSA molecule was found to be mechanically stable from the diagonal elements of the Hessian matrix (Table 2) indicating that the Born criteria of stability were satisfied [16].

Table 2. Elements of the mechanical stiffness $(\mathrm{GPa})$ of the predicted most stable crystal of AMSA molecule.

\begin{tabular}{|l|c|c|c|c|c|c|c|}
\hline $\begin{array}{l}\text { Predicted } \\
\text { conformer }\end{array}$ & $C_{11}$ & $C_{22}$ & $C_{33}$ & $C_{44}$ & $C_{55}$ & $C_{66}$ & $\begin{array}{c}\text { Young } \\
\text { modulus } \\
(\mathrm{GPa})\end{array}$ \\
\hline STR1 & 74.2 & 25.8 & 100.6 & 23.8 & 40.8 & 19.7 & 51.1 \\
\hline
\end{tabular}

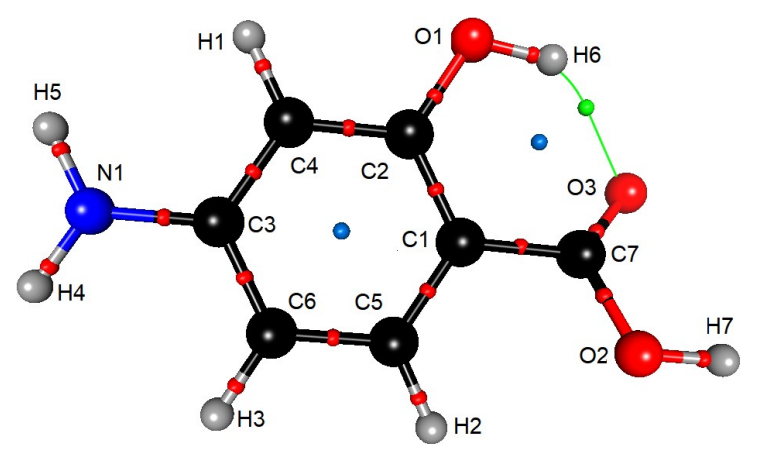

monomer

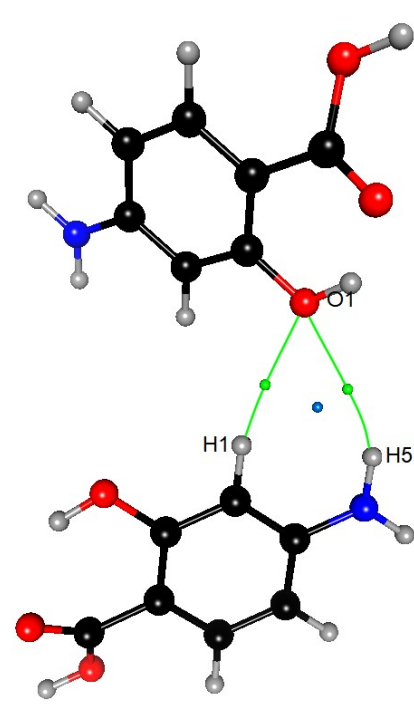

dimer 1 

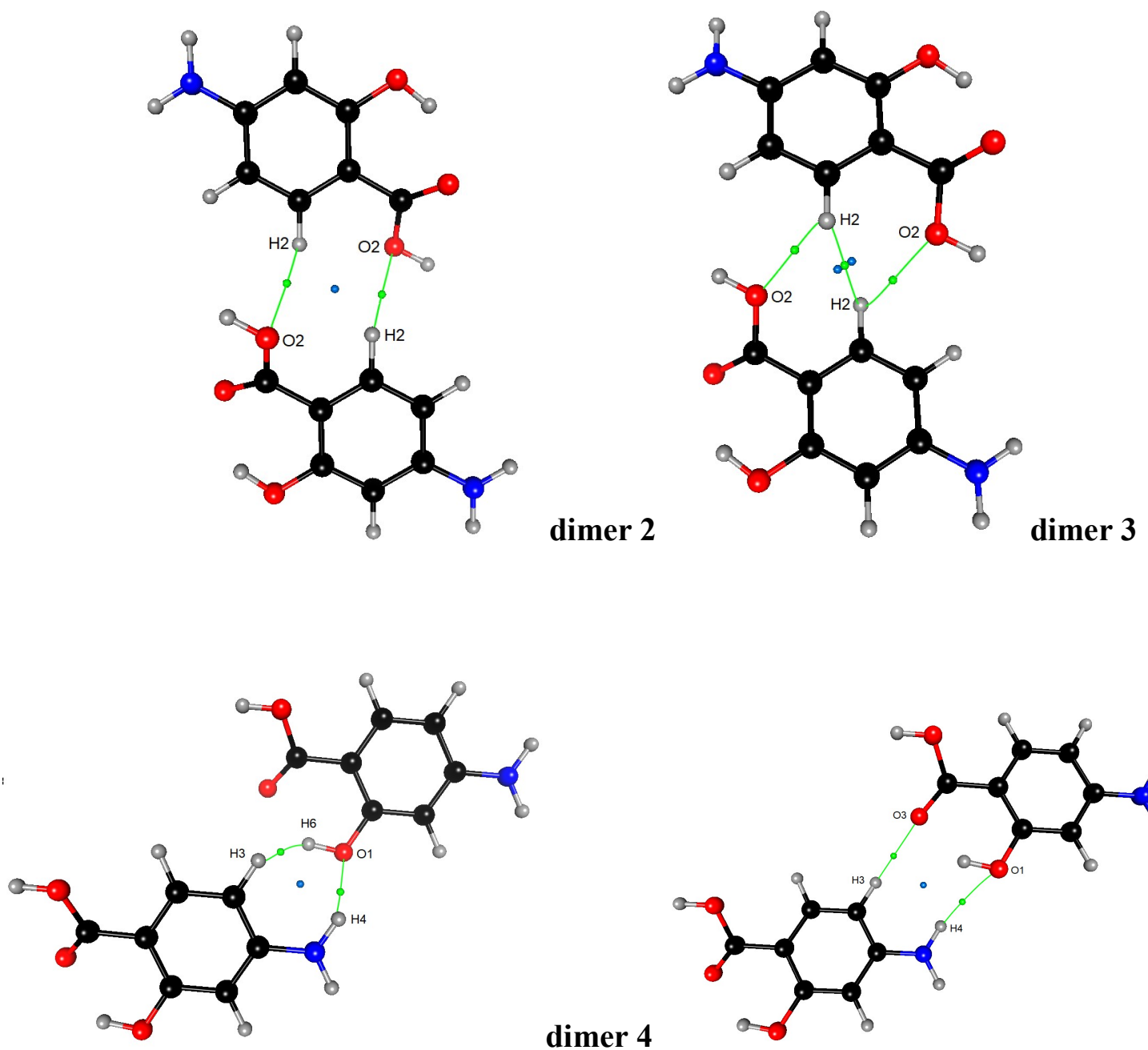

dimer 4

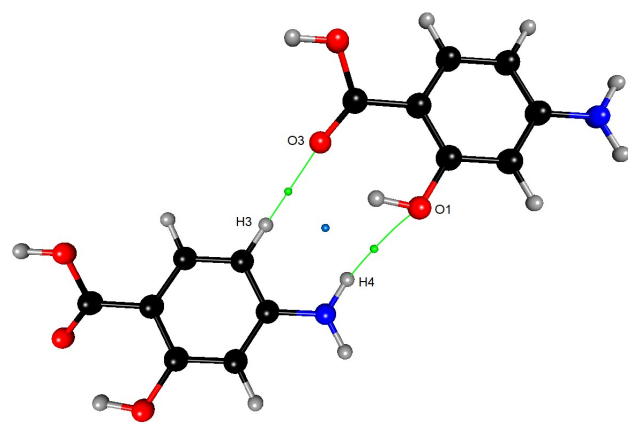

dimer5

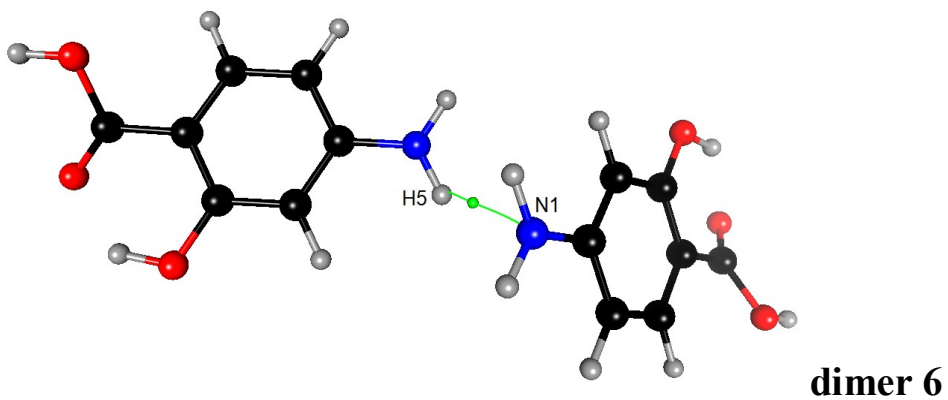




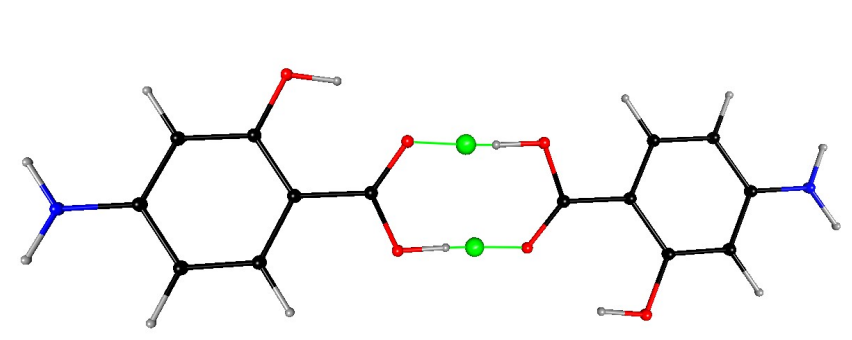

Dimer 7

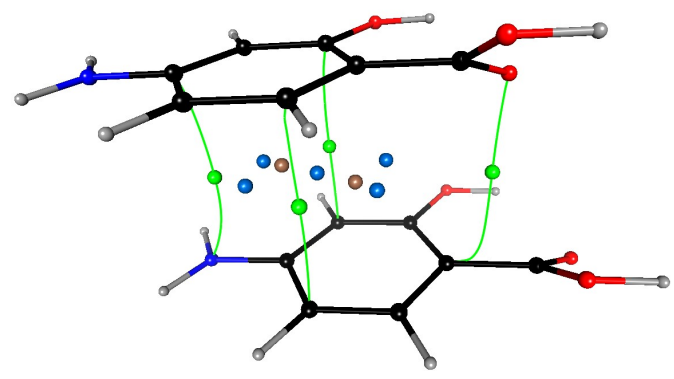

Dimer 8

Figure 2. Molecular graph of the monomer and of the eight independent dimers of STRI crystal structure displaying bond paths (green curves) and critical points (CP).

$(3,-1)$ intermolecular bonding CPs are shown as green spheres. Saddle $(3,+1)$ CPs are in blue and cage $(3,+3)$ CPs are in brown.

Table 3 Hydrogen bonds prevailed in the predicted [STR 1] / [EXP] crystal

\begin{tabular}{|lllll|}
\hline $\mathrm{D}-\mathrm{H} \cdots \mathrm{A}$ & $\mathrm{D}-\mathrm{H}(\AA)$ & $\mathrm{H} \cdots \mathrm{A}(\AA)$ & $\mathrm{D} \cdots \mathrm{A}(\AA)$ & $\mathrm{D}-\mathrm{H} \cdots \mathrm{A}\left({ }^{\circ}\right)$ \\
\hline $\mathrm{O} 1-\mathrm{H} 6 \cdots \mathrm{O} 3 *$ & 0.976 & $1.970 / 1.790$ & $2.755 / 2.611$ & $135.9 / 149.5$ \\
$\mathrm{O} 2-\mathrm{H} 7 \cdots \mathrm{O} 3 \# 8$ & 1.015 & $1.738 / 1.663$ & $2.749 / 2.640$ & $173.7 / 174.4$ \\
\hline $\mathrm{N} 1-\mathrm{H} 5 \cdots \mathrm{O} 1 \# 1$ & 1.009 & $3.133 / 2.127$ & $4.031 / 3.137$ & $149.0 / 173.3$ \\
$\mathrm{~N} 1-\mathrm{H} 4 \cdots \mathrm{O} 1 \# 4$ & 1.009 & $2.211 / 2.531$ & $2.959 / 3.337$ & $129.7 / 136.1$ \\
$\mathrm{~N} 1-\mathrm{H} 4 \cdots \mathrm{O} 1 \# 5$ & 1.009 & $2.757 / 2.531$ & $3.545 / 3.337$ & $135.2 / 136.1$ \\
\hline $\mathrm{N} 1-\mathrm{H} 5 \cdots \mathrm{N} 1 \# 69$ & 1.009 & $2.359 / 3.223$ & $2.834 / 3.394$ & $107.8 / 93.3$ \\
$\mathrm{~N} 1-\mathrm{H} 5 \cdots \mathrm{N} 1 \# 7$ & 1.009 & $2.056 / 3.136$ & $2.834 / 3.394$ & $132.2 / 99.1$ \\
\hline $\mathrm{C} 4-\mathrm{H} 1 \cdots \mathrm{O} 1 \# 1$ & 1.083 & $2.772 / 3.439$ & $3.811 / 4.095$ & $160.6 / 128.1$ \\
$\mathrm{C} 5-\mathrm{H} 2 \cdots \mathrm{O} 2 \# 2$ & 1.083 & $2.738 / 2.660$ & $3.566 / 3.527$ & $133.1 / 136.7$ \\
$\mathrm{C} 5-\mathrm{H} 2 \cdots \mathrm{O} 2 \# 3$ & 1.083 & $2.591 / 2.757$ & $3.238 / 3.527$ & $117.6 / 138.5$ \\
$\mathrm{C} 6-\mathrm{H} 3 \cdots \mathrm{O} 3 \# 5$ & 1.083 & $2.764 / 2.840$ & $3.506 / 3.507$ & $125.5 / 128.1$ \\
\hline
\end{tabular}

\footnotetext{
* Intramolecular interaction;

Symmetry operators : $\# 1-\mathrm{x}+1 / 2,+\mathrm{y}-1 / 2,-\mathrm{z}+1 / 2+1 ; \# 2-\mathrm{x},-\mathrm{y}-1,-\mathrm{z}+2 ; \# 3-\mathrm{x},-\mathrm{y},-\mathrm{z}+2$;

$\# 4+\mathrm{x}-1,+\mathrm{y},+\mathrm{z} ; \# 5+\mathrm{x}-1,+\mathrm{y}+1,+\mathrm{z} ; \quad \# 6-\mathrm{x}-1 / 2,+\mathrm{y}-1 / 2,-\mathrm{z}^{3} / 2 ; \quad \# 7-\mathrm{x}-1 / 2,+\mathrm{y}+1 / 2,-\mathrm{z}+3 / 2 ;$

$\# 8-\mathrm{x}+1,-\mathrm{y}-1,-\mathrm{z}+2$
}

I no bond path, nor critical point, there is bond path instead between N1 and H5 ${ }^{\# 6}$, which is reciprocal of $\mathrm{H} 5 \cdots \mathrm{N1} 1^{\# 7}$ 


\subsection{Intermolecular interactions}

Thermodynamic stability of the predicted conformer was further analyzed in detail from the possible intermolecular hydrogen bonds prevailed in the system. As the crystallization mechanism of the molecule depends on the ability to achieve strong interactions, the possible short contacts were studied from the PARST [28] analysis (Table 3). The interacting dimers stabilizing the structure are shown in Fig. 2.

The hydrogen bond analysis reveals the stabilized nature of the predicted structure. The investigation to perceive the contribution of the intermolecular short contacts towards the crystal stability was implemented from the two dimensional fingerprint plot of the Hirshfeld surface using the Crystal explorer package [29] (Fig.3).

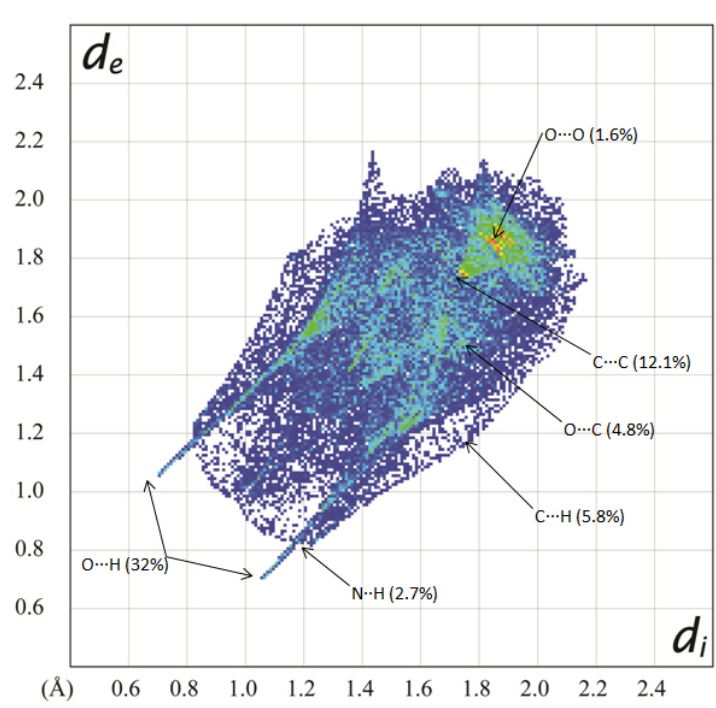

(a)

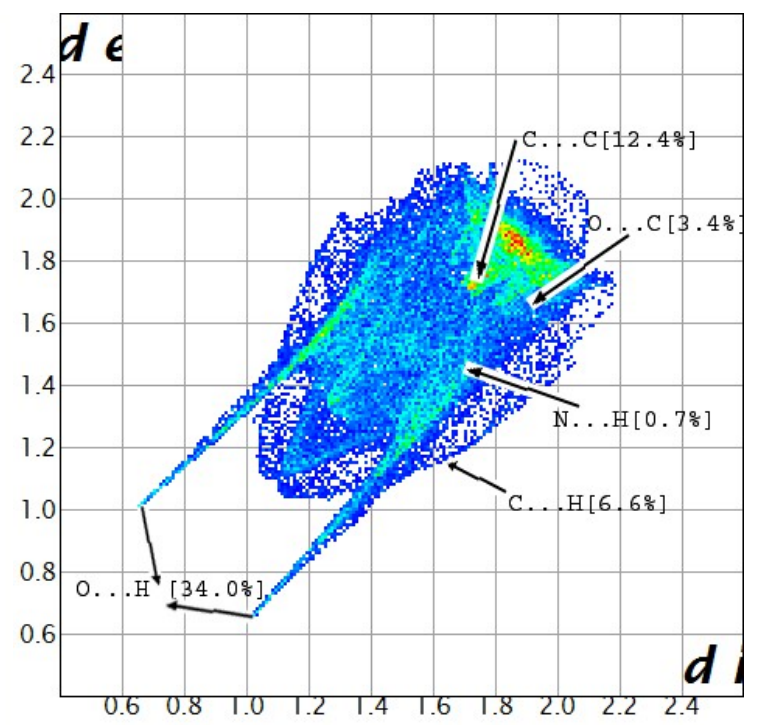

(b)

Figure 3. Two dimensional fingerprint plots in crystal stacking of (a) predicted [STR 1] and (b) experimental AMSA

H...H contacts contribute to $39.8 \%$ and $39.5 \%$ over the total Hirshfeld Surface (HS) area of the predicted and experiment crystal structures, respectively. The shortest distance $d(\mathrm{H} 5, \mathrm{H} 5)=1.913$ $\AA$ is found in dimer 3 of STR1 between two $\mathrm{NH}_{2}$ groups, while the equivalent distance is 3.206 in EXP structure. In EXP crystal, $\mathrm{d}(\mathrm{H} 1, \mathrm{H} 1)=2.305 \AA$ in dimer 1 is the shortest $\mathrm{H}$...H contact. 
The hydrogen atoms of the $\mathrm{NH}_{2}$ functional group form a $\mathrm{H}$-bond with the phenol oxygen atom (dimer 1) and interact with the nitrogen atom, perpendicularly to the $\mathrm{NH}_{2}$ moiety (dimer 6). The $\mathrm{H} \ldots \mathrm{N}$ interactions represent a small proportion of the HS area (pred:2.7\%/exp:0.7\%).

The shortest $\mathrm{O} \ldots \mathrm{H}$ interaction is found in dimer 7. This corresponds to the double hydrogen atom in the $(\mathrm{COOH})_{2}$ homo-synthon [30] and is presumably the strongest electrostatic interaction in the crystal. The Hirshfeld surface analysis reveals the dominant nature of the $\mathrm{O} \cdots \mathrm{H} / \mathrm{H} \cdot \mathrm{O}$ interactions via the terminal acid functional groups attached to the aromatic ring. The 2D fingerprint plot of the Hirshfeld surface exhibits the spikes of the $\mathrm{O} \cdots \mathrm{H} / \mathrm{H} \cdot \mathrm{O}$ interaction towards the lowest $\left(d_{i}, d_{e}\right)$ region. The phenol $\mathrm{O}-\mathrm{H}$ group is involved as donor in an intramolecular $\mathrm{O}-\mathrm{H} . . . \mathrm{O}$ hydrogen bond towards the $\mathrm{O}=\mathrm{C}$ oxygen atom.

Dimers \#2 and \#3 show some similarity as molecules have the same relative orientations (rotation) but different translation. Furthermore, the dimer 8 is due to C...C interactions which correspond to parallel displaced cycle stacking. The stacking interaction of the aromatic carbon atoms can also be seen in Fig. 4 showing the Hirshfeld surface and some neighbor molecules.

The fingerprint plot also highlights the spikes at short distance of the $\mathrm{N}{ }^{\cdots} \mathrm{H} / \mathrm{H}{ }^{*} \mathrm{~N}$ contacts, indicating the strong interaction.

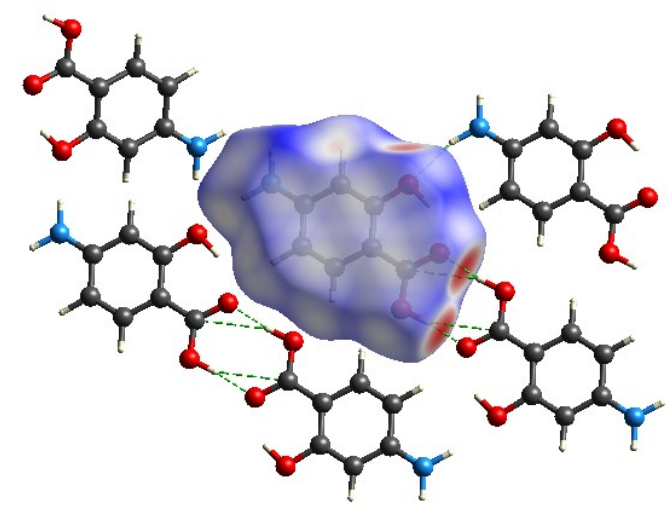

(a)

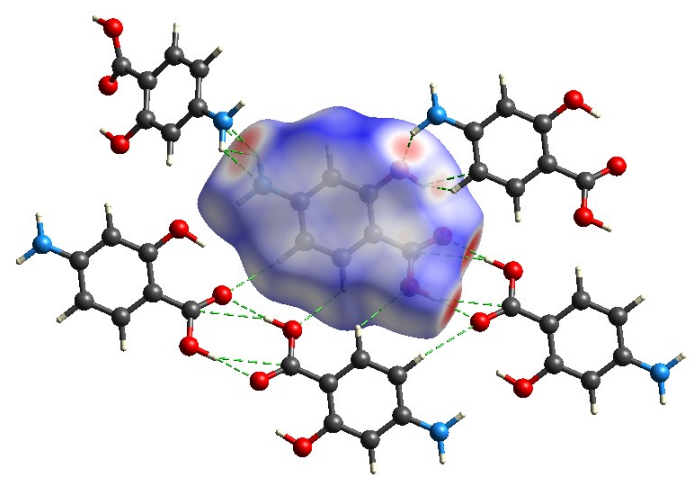

(b)

Figure 4 : Hirshfeld surface of the AMSA molecule showing the intermolecular interactions for both (a) Experiment and (b) Predicted structure

The above trend in the interaction energies was further evident from contact enrichment ratio [31] and \% contacts listed in Table 4. 
Table 4. Nature of intermolecular contacts on the Hirshfeld surface by chemical types and their enrichment. Hc Hydrogen atoms bound to carbon are distinguished from the more polar Hp bound to $\mathrm{O}$ and $\mathrm{N}$. The major contacts and most enriched ones are highlighted in bold characters. The last two lines show the surface content and contact enrichment globally in terms of polar (pol) charged atoms and non-polar (np), C and Hc atoms.

\begin{tabular}{|c|c|c|c|c|c|c|c|c|c|c|}
\hline & \multicolumn{5}{|c|}{ Experimental } & \multicolumn{5}{|c|}{ Predicted } \\
\hline chem. & $\mathrm{O}$ & $\mathrm{Hp}$ & $\mathrm{N}$ & $\mathrm{Hc}$ & $\mathrm{C}$ & $\mathrm{O}$ & $\mathrm{Hp}$ & $\mathrm{N}$ & $\mathrm{Hc}$ & $\mathrm{C}$ \\
\hline surf. \% & 21.1 & 25.8 & 4.0 & 18.3 & 30.8 & 21.4 & 24.0 & 4.3 & 20.0 & 30.3 \\
\hline $\mathrm{O}$ & 0.3 & & $\%$ & contacts & & 0.6 & & $\%$ & contacts & \\
\hline Hp & 20.2 & 8.0 & & & & 16.4 & 6.1 & & & \\
\hline $\mathrm{N}$ & 0.0 & 2.5 & 0.7 & & & 0.3 & 6.2 & 0.0 & & \\
\hline $\mathrm{Hc}$ & 13.9 & 9.9 & 0.0 & 4.6 & & 15.9 & 9.7 & 0.0 & 5.2 & \\
\hline $\mathrm{C}$ & 5.9 & 5.0 & 3.7 & 5.2 & 20.1 & 8.2 & 5.9 & 2.1 & 4.0 & 19.4 \\
\hline $\mathrm{O}$ & 0.07 & & & enrich- & & 0.15 & & & enrich- & \\
\hline $\mathrm{Hp}$ & 1.86 & 1.11 & & ment & & 1.55 & 0.96 & & ment & \\
\hline $\mathrm{N}$ & 0.00 & 1.22 & 4.77 & & & 0.14 & 2.88 & 0 & & \\
\hline $\mathrm{Hc}$ & 1.78 & 0.97 & 0.03 & 1.26 & & 1.89 & 0.96 & 0 & 1.30 & \\
\hline $\mathrm{C}$ & 0.49 & 0.31 & 1.63 & 0.45 & 2.23 & 0.66 & 0.4 & 0.82 & 0.34 & 2.24 \\
\hline surf. \% & & 50.9 & & 49.1 & & & 49.7 & & 50.3 & \\
\hline enrich. & pol,pc & 1.22 & p.np 1 . & $4 \quad$ pol.n & 0.77 & pol,pc & 1.20 & p.np 1.13 & pol.np & \\
\hline
\end{tabular}

Globally, the EXP and STR1 crystals show similar contact statistics, the \% contacts being $96.2 \%$ correlated. The major contacts are of O...Hp (O..H-O and O...H-N hydrogen bonds) and C...C representing aromatic cycle stacking, followed by weak C-H...O hydrogen bonds. Hp..Hp contacts are due to the proximity of $\mathrm{NH}_{2}$ groups hydrogen-bonded with the phenol oxygen atom. The predicted STR1 structure shows a much stronger occurrence of N-H...N contacts than in the EXP crystal. This interaction is however not in a hydrogen bond as its electrostatic energy (computed after ELMAM2 database transfer is very small) $E_{\text {elec }}(\mathrm{H} 5, \mathrm{~N} 1) \approx-10^{-3} \mathrm{~kJ} / \mathrm{mol}$ and the $\mathrm{NH}_{2}$ nitrogen atom does not show any electron lone pair above or below the $\mathrm{sp}^{2}$ plane.

The C...C contact is the most enriched in the EXP structure due to parallel displaced aromatic cycle stacking. Such molecule made of a heterocycle bearing electropositive and electronegative atoms is prone to stacking displaying good electrostatic complementarity.

The non-polar atoms $(\mathrm{C}$ and $\mathrm{Hc})$ as well as the charged $(\mathrm{O}, \mathrm{Hp}, \mathrm{N})$ atoms represent globally approximately half of the Hirshfeld surface. The polar...polar and non-polar...non-polar contact types are both slightly enriched $\left(E_{\exp }>1.2\right)$ showing the over-represented occurrence of 
electrostatic and of hydrophobic interactions. On the other hand, cross polar...non-polar contacts $\left(E_{\exp }=0.77\right)$ are slightly under-represented. The weak C-H...O hydrogen bonds represent however an exception, it is a major contact which is significantly enriched $\left(E_{\exp }=1.78\right)$

\subsection{Molecular Structure}

The STR1 AMSA molecule exhibits a close to co-planar geometry with $30^{\circ}$ torsion angle for the carboxylic acid and minimal deviation of $0.07^{\circ}$ for the amine and $3.2^{\circ}$ for the alcohol groups. This small deviation is not influenced much in the C-C bond lengths $[\sim 1.395 \AA]$ and internal CC-C bond angles $\left[\sim 120^{\circ}\right]$. The strong electron withdrawing nature of the amine and carboxylic acid group leads to larger bond distances for C3-N1 [1.410 $\AA]$ and C1-C7 [1.457 $\AA]$. The molecular structure of AMSO exhibits the intramolecular $\mathrm{H}-$ bond $\mathrm{O} 1-\mathrm{H} 6 \cdots \mathrm{O} 3$, which forms a five membered ring (Fig. 5a). Moreover, this intramolecular interaction dilutes the H-bond donor capabilities of $-\mathrm{OH}$ group and makes the carboxylic and amine group having major contribution in intermolecular hydrogen bonding interactions. The structure is indeed stabilized by $\mathrm{N}-\mathrm{H} \cdots \mathrm{O}$

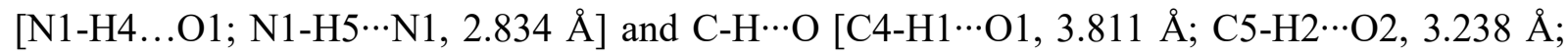

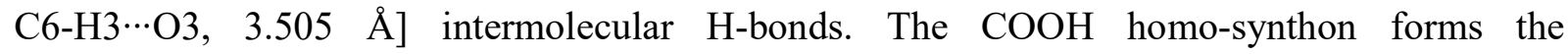

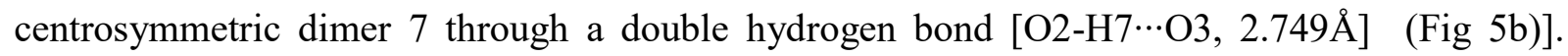
These dimers are stacked parallel by means of C6 ${ }^{\cdots} \mathrm{C} 5 \quad(3.473 \AA), \mathrm{C} 4 \cdots \mathrm{C} 2 \quad(3.473 \AA)$, $\mathrm{C} 1 \cdots \mathrm{O} 3(3.250 \AA)$ and $\mathrm{N} 1 \cdots \mathrm{C} 3(3.474 \AA)$ interactions.

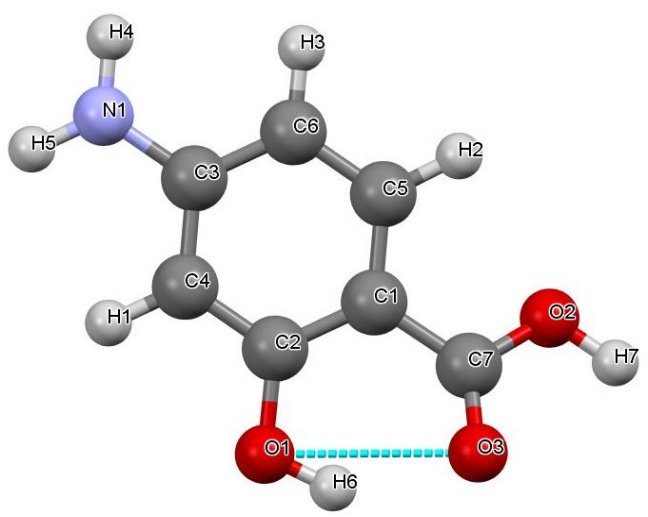

(a)

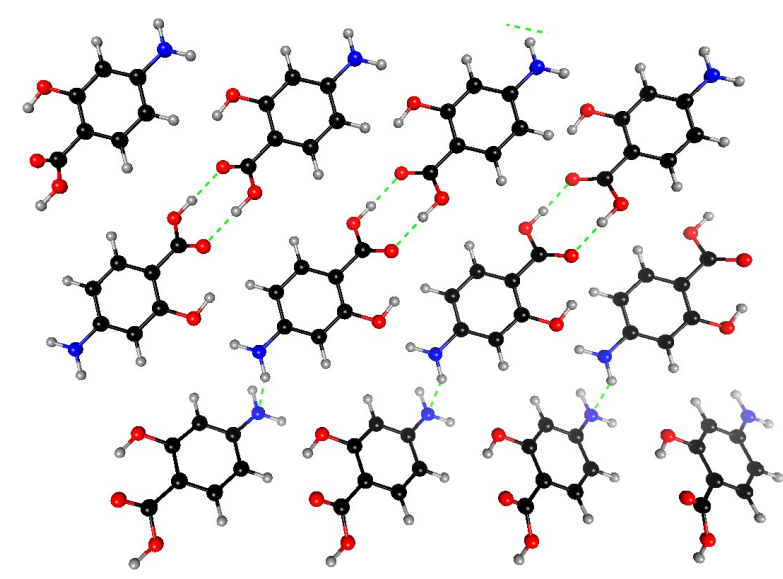

(b) 
Figure 5. Energy minimized (a) gas phase conformer and (b) Autostereogram AMSA molecule in STR1 predicted FC crystal (global minimum) showing $\mathrm{O}-\mathrm{H} \cdots \mathrm{O}$ interactions. a axis is horizontal.

\subsection{Open Shell Interactions}

The $(3,-1)$ covalent bond critical point (BCP) [32] were characterized in AMSA molecule for the calculation using $\boldsymbol{w B 9 7 X - D} 6-311 G++(d, P)$ basis set. The complete topological parameters associated with $(3,-1)$ BCP in the theoretical electron density are listed in supplementary Table S1. The topological values at the BCPs after ELMAM2 electron density transfer are also shown. The electron density $\rho_{\mathrm{cp}}$ and Laplacian $\nabla^{2} \rho_{\mathrm{cp}}$ values show respectively an 88 and $91 \%$ correlation coefficient, after theoretical calculation and ELMAM2 transfer. The corresponding contour plots of theoretical electron density and Laplacian 2D maps are shown in Figures S1 and S2.

\subsection{Closed Shell Interactions}

The molecular crystal stability by means of intermolecular interactions was investigated via QTAIM approach. Table 5 shows the topological parameters for the main interactions prevailed in the AMSA crystal. This includes the $\mathrm{C} \cdots \mathrm{C}, \mathrm{C} \cdots \mathrm{O}, \mathrm{C} \cdots \mathrm{N}$ and $\mathrm{H} \cdots \mathrm{H}$ interactions with distances of $3.473 \AA, 3.250 \AA, 3.474 \AA$ and $2.332 \AA$ respectively. The existence of these interactions was further observed in QTAIM analysis by locating the bond critical points (BCP) on the bond path between dimers \#3, \#4 and \#8 (Fig. 2). The investigation was extended further by finding CPs of the $\mathrm{O}-\mathrm{H} \ldots \mathrm{O}$ intermolecular $\left[\mathrm{O} 2-\mathrm{H} 7 \ldots 3^{\# 8}\right]$ and intramolecular hydrogen bond [O1-H6...O3] with the energy values of $-44.8 \mathrm{~kJ} / \mathrm{mol}$ and $-26.3 \mathrm{~kJ} / \mathrm{mol}$ respectively (Table 5 ). The topological parameters for these interactions $\left[\rho\left(\mathbf{r}_{\mathrm{cp}}\right)\right.$ and $\left.\nabla^{2} \rho\left(\mathbf{r}_{\mathrm{cp}}\right)\right]$ at the BCP reveal that these are the strongest non-covalent interactions prevailed in the AMSA crystal structure.

Following to the O-H...O interactions, the two N-H..N hydrogen bonds were found to be strong as their average energy value is about $-24.1 \mathrm{~kJ} / \mathrm{mol}$.

Unlike $\mathrm{N} 1-\mathrm{H} 4 \ldots \mathrm{O}^{\# 4}[-13.1 \mathrm{~kJ} / \mathrm{mol}]$, the energy of $\mathrm{N} 1-\mathrm{H} 4 \ldots \mathrm{O} 1^{\# 5}[-3.6 \mathrm{~kJ} / \mathrm{mol}]$ and $\mathrm{N} 1-$ $\mathrm{H} 5 \ldots \mathrm{O} 1^{\# 1}[-1.2 \mathrm{~kJ} / \mathrm{mol}]$ intermolecular H-bonds are weak and are comparable with those of C$\mathrm{H}$... O interactions $\left[\mathrm{C} 4-\mathrm{H} 1 \ldots \mathrm{O} 1^{\# 1}, 3.6 \mathrm{~kJ} / \mathrm{mol}, \mathrm{C} 5-\mathrm{H} 2 \ldots \mathrm{O} 2^{\# 2},-4.5 \mathrm{~kJ} / \mathrm{mol}, \mathrm{C} 5-\mathrm{H} 2 \ldots \mathrm{O} 2^{\# 3},-6.3\right.$ $\mathrm{KJ} / \mathrm{mol}$ and $\mathrm{C} 6-\mathrm{H} 3 \ldots \mathrm{O} 3^{\# 5},-5.4 \mathrm{~kJ} / \mathrm{mol}$. The weak characters of $\mathrm{N} 1-\mathrm{H} 4 \ldots \mathrm{O} 1^{\# 5}$ and $\mathrm{N} 1-\mathrm{H} 5 \ldots \mathrm{O} 1^{\# 1}$ 
interactions are attributed to the low values of total energy density, $H(\mathbf{r})\left[1.7 \mathrm{H} / \AA^{3}\right.$ and $1.2 \mathrm{H} /$ $\left.\AA^{3}\right]$ at the BCP, whereas for the interaction $\mathrm{N} 1-\mathrm{H} 4 \ldots \mathrm{O} 1^{\# 4}$, it reaches $4.8 \mathrm{~kJ} / \mathrm{mol}$. The energy of the N-H...O hydrogen bonds correlate also with the H...O distances.

Among C-H...O intermolecular interactions, C5-H2...O2 $2^{\# 3}$ and $\mathrm{C} 6-\mathrm{H} 3 \ldots \mathrm{O} 3^{\# 5}$ have a major contribution in the molecular self-assembly of AMSA. The calculated energies for these interactions were $-6.3 \mathrm{~kJ} / \mathrm{mol}$ and $-5.4 \mathrm{~kJ} / \mathrm{mol}$ respectively. Closed shell and open shell interactions are characterized by $|V(\mathbf{r})| / G(\mathbf{r})<1$ for closed shell and $>2$ for open shell, respectively, where $V(\mathbf{r})$ and $G(\mathbf{r})$ are the local potential and kinetic energy density as proposed by Espinosa et al. [33].

Table 6 shows the interaction energies $E_{\text {int }}$ calculated from counterpoise method [34] for the monomer as well as for 8 dimers. Except dimer 7 and dimer 8, the interaction energies $E_{\text {int }}$ of all other dimers are of smaller magnitude. The strong binding energies of dimer 7 shows that the molecular self-assembly is, in first instance, governed by the double O-H...O hydrogen bond involving the $\mathrm{COOH}$ homo-synthon which yields a centrosymmetric dimer. Dimer 8 has the second strongest $E_{\text {tot }}$ energy as it has a large stacking interaction surface and is principally dispersive. Usually, $\mathrm{O}-\mathrm{H} \cdots \mathrm{O}$ interactions have strong to medium hydrogen bond characteristics which are in good agreement with QTAIM study for $E_{\text {bond }} \mathrm{O} 2-\mathrm{H} 7 \ldots \mathrm{O} 3^{\# 8}[-44.8 \mathrm{~kJ} / \mathrm{mol}]$.

Dimers 2 and 3 show similar relative orientation of the molecules as their symmetry operators differ by a translation along the short $\mathbf{b}$ axis. The $\mathrm{O} 2$ and $\mathrm{H} 2$ atoms display bifurcated $\mathrm{O} 2 \ldots \mathrm{H} 2$ hydrogen bonds involving the two dimers (Fig. 2). Dimers 4 and 5 share also some similarity, both having N1-H4...O1 and C6-H3...O3 bifurcated hydrogen bonds.

Table 5. List of the dimer interactions prevailed in the predicted AMSA structure [STR 1] and topological properties at the critical points. $G, V$ and $H$ are the kinetic, potential and total energy density respectively. $E_{\text {Hbond }}=1 / 2 V(\mathbf{r})$ bond is the dissociation energy described in the article Espinosa et al. 2001 [33].

\begin{tabular}{|l|c|c|c|c|c|c|c|}
\hline \multicolumn{1}{|c|}{ Interaction } & $\begin{array}{c}\text { density } \\
\rho\left(\mathrm{e} / \AA^{3}\right)\end{array}$ & $\begin{array}{c}\text { Laplacian } \\
\left(\mathrm{e} / \AA^{5}\right)\end{array}$ & $\begin{array}{c}G(\mathbf{r}) \\
(\text { a.u. })\end{array}$ & $\begin{array}{c}V(\mathbf{r}) \\
(\text { a.u. })\end{array}$ & $\begin{array}{c}H(\mathbf{r}) \\
\left(\mathrm{kJ} / \mathrm{B}^{3} / \mathrm{mol}\right)\end{array}$ & $\begin{array}{c}|V(\mathbf{r})| \\
/ G(\mathbf{r})\end{array}$ & $\begin{array}{c}E_{\text {Hbond }} \\
(\mathrm{kJ} / \mathrm{mol})\end{array}$ \\
\hline${\mathrm{O} 1-\mathrm{H} 6 \ldots \mathrm{O} 3^{*}}^{\mathrm{C} 4-\mathrm{H} 1 \ldots \mathrm{O} 1^{\# 1}}$ & 0.0258 & 0.0945 & 0.0218 & -0.0200 & 4.73 & 0.91 & -26.3 \\
\hline $\mathrm{N} 1-\mathrm{H} 5 \ldots 1^{\# 1}$ & 0.0047 & 0.0148 & 0.0032 & -0.0027 & 1.24 & 0.85 & -3.6 \\
\hline $\mathrm{C} 5-\mathrm{H} 2 \ldots 2^{\# 2}$ & 0.0057 & 0.0075 & 0.0014 & -0.0010 & 1.19 & 0.68 & -1.2 \\
\hline $\mathrm{C} 5-\mathrm{H} 2 \ldots \mathrm{O} 2^{\# 3}$ & 0.0078 & 0.0267 & 0.0058 & -0.0048 & 2.43 & 0.84 & -6.3 \\
\hline $\mathrm{H} 2 \ldots \mathrm{H}^{\# 3}$ & 0.0031 & 0.0120 & 0.0023 & -0.0017 & 1.74 & 0.72 & \\
\hline $\mathrm{H} 3 \ldots \mathrm{H}^{\# 4}$ & 0.0095 & 0.0330 & 0.0068 & -0.0054 & 3.76 & 0.79 & \\
\hline
\end{tabular}




\begin{tabular}{|l|l|l|l|l|l|l|l|}
$\mathrm{N} 1-\mathrm{H} 4 \ldots \mathrm{O} 1^{\# 4}$ & 0.0151 & 0.0544 & 0.0118 & -0.0099 & 4.79 & 0.84 & -13.1 \\
\hline $\mathrm{C} 6-\mathrm{H} 3 \ldots \mathrm{O} 3^{\# 5}$ & 0.0068 & 0.0233 & 0.0050 & -0.0041 & 2.22 & 0.83 & -5.4 \\
\hline $\mathrm{N} 1-\mathrm{H} 4 \ldots \mathrm{O} 1^{\# 5}$ & 0.0044 & 0.0161 & 0.0034 & -0.0027 & 1.68 & 0.81 & -3.6 \\
\hline $\mathrm{N} 1-\mathrm{H} 5 \ldots \mathrm{N} 1^{\# 6}$ & 0.0256 & 0.0938 & 0.0209 & -0.0184 & 6.68 & 0.88 & -24.1 \\
\hline $\mathrm{N} 1-\mathrm{H} 5 \ldots \mathrm{N} 1^{\# 7}$ & 0.0256 & 0.0938 & 0.0209 & -0.0184 & 6.68 & 0.88 & -24.1 \\
\hline $\mathrm{O} 2-\mathrm{H} 7 \ldots \mathrm{O} 3^{\# 8}$ & 0.0398 & 0.1173 & 0.0317 & -0.0341 & -6.31 & 1.087 & -44.8 \\
\hline $\mathrm{N} 1 \ldots \mathrm{C} 3^{\# 9}$ & 0.0046 & 0.0148 & 0.0030 & -0.0023 & 1.86 & 0.76 & \\
\hline $\mathrm{C} 6 \ldots 5^{\# 9}$ & 0.0053 & 0.0144 & 0.0029 & -0.0022 & 1.89 & 0.75 & \\
\hline $\mathrm{C} 1 \ldots \mathrm{O} 3^{\# 9}$ & 0.0065 & 0.0223 & 0.0046 & -0.0036 & 2.64 & 0.78 & \\
\hline $\mathrm{C} 4 \ldots \mathrm{C} 2^{\# 9}$ & 0.0050 & 0.0141 & 0.0028 & -0.0021 & 1.93 & 0.74 & \\
\hline
\end{tabular}

* Intramolecular interaction; $\# 1-\mathrm{x}+1 / 2,+\mathrm{y}+1 / 2,-\mathrm{z}+1 / 2+1 ; \# 2-\mathrm{x},-\mathrm{y}-1,-\mathrm{z}+2 ; \# 3-\mathrm{x},-\mathrm{y},-\mathrm{z}+2 ; \# 4+\mathrm{x}-1,+\mathrm{y},+\mathrm{z} ; \# 5+\mathrm{x}-1$, $+\mathrm{y}+1,+\mathrm{z} ; \# 6-\mathrm{x}-1 / 2,+\mathrm{y}-1 / 2,-\mathrm{z}+1 / 2+1 ; \# 7-\mathrm{x},-1 / 2,+\mathrm{y}+1 / 2,-\mathrm{z}+1 / 2+1 ; \# 8-\mathrm{x}+1,-\mathrm{y}-1,-\mathrm{z}+2 ; \# 9+\mathrm{x},+\mathrm{y}+1,+\mathrm{z}$

Table 6. Single point energy values $E_{\mathrm{wB} 97 \mathrm{X}-\mathrm{D}}$ (in atomic units) for the monomer and the independant dimers of predicted AMSA [STR 1]. Interaction energy, $E_{\text {int }}=E_{\text {dimer }}-2 E_{\text {monomer }}$ (in $\mathrm{kJ} / \mathrm{mol})$.

\begin{tabular}{|l|c|c|}
\hline & $\begin{array}{c}E_{\mathrm{wB} 97 \mathrm{X}-\mathrm{D}} \\
(\text { a.u. })\end{array}$ & $\begin{array}{c}E_{\text {int }} \\
(\mathrm{kJ} / \mathrm{mol})\end{array}$ \\
\hline Monomer & -551.4028 & - \\
\hline Dimer 1 & -1102.8109 & -14.1 \\
\hline Dimer 2 & -1102.8093 & -9.8 \\
\hline Dimer 3 & -1102.8086 & -8.0 \\
\hline Dimer 4 & -1102.8095 & -10.3 \\
\hline Dimer 5 & -1102.8111 & -14.4 \\
\hline Dimer 6 & -1102.8061 & -1.4 \\
\hline Dimer 7 & -1102.8356 & -78.9 \\
\hline Dimer 8 & -1102.8178 & -32.1 \\
\hline
\end{tabular}

\subsection{Energy of molecular dimers}

The molecules in the experimental and predicted crystal structure are packed in a ribbon pattern and establish C-H...O, N-H...O, N-H...N and O-H...O types of hydrogen bonds. The dimer with $\mathrm{COOH} . . . \mathrm{COOH}$ homo-synthon is highly electrostatic. Moreover, it is, by far, the dimer with strongest total energy.

It appears that most other packings are predominantly stabilized by dispersion energies in both the experimental and predicted crystal structures (Table 7). All the three energy frameworks for the experimental and predicted structures are shown in the Fig. 6. 
From the pixel method, the intermolecular energy between 8 molecular pairs (dimers) were calculated and are listed in Table 8 for both predicted and experimental crystal structures. The $E_{\text {tot }}$ energy values of predicted packing agree generally with the $E_{\text {int }}$ values calculated from counterpoise method. Also, most of the interaction energy values of the dimers found in the experimental and predicted crystal structures are comparable except for dimer 1, framed by $\mathrm{C} 4$ $\mathrm{H} 1 \ldots . \mathrm{O} 1$ and $\mathrm{N} 1-\mathrm{H} 5 \ldots . . \mathrm{O} 1$ interactions. The corresponding total energy values are $-31.6 \mathrm{~kJ} / \mathrm{mol}$ [experiment] and $-13.6 \mathrm{~kJ} / \mathrm{mol}$ [predicted]. Regarding the $\mathrm{O}-\mathrm{H} \ldots \mathrm{O}$ interaction, the strong interaction energy was calculated for dimer 7 , in which the carboxylic group interact with the same of the neighboring molecule yielding $E_{\text {tot }}$ values of -71.3 and $-61.1 \mathrm{~kJ} / \mathrm{mol}$ for experiment and predicted crystal structures respectively.

Globally, the $E_{\mathrm{wB} 97 \mathrm{X}-\mathrm{D}}$ dimer internal energies (Table 6) are $95.7 \%$ correlated with the PIXEL $E_{\text {tot }}$ values (Table 7).

Coloumb Predicted




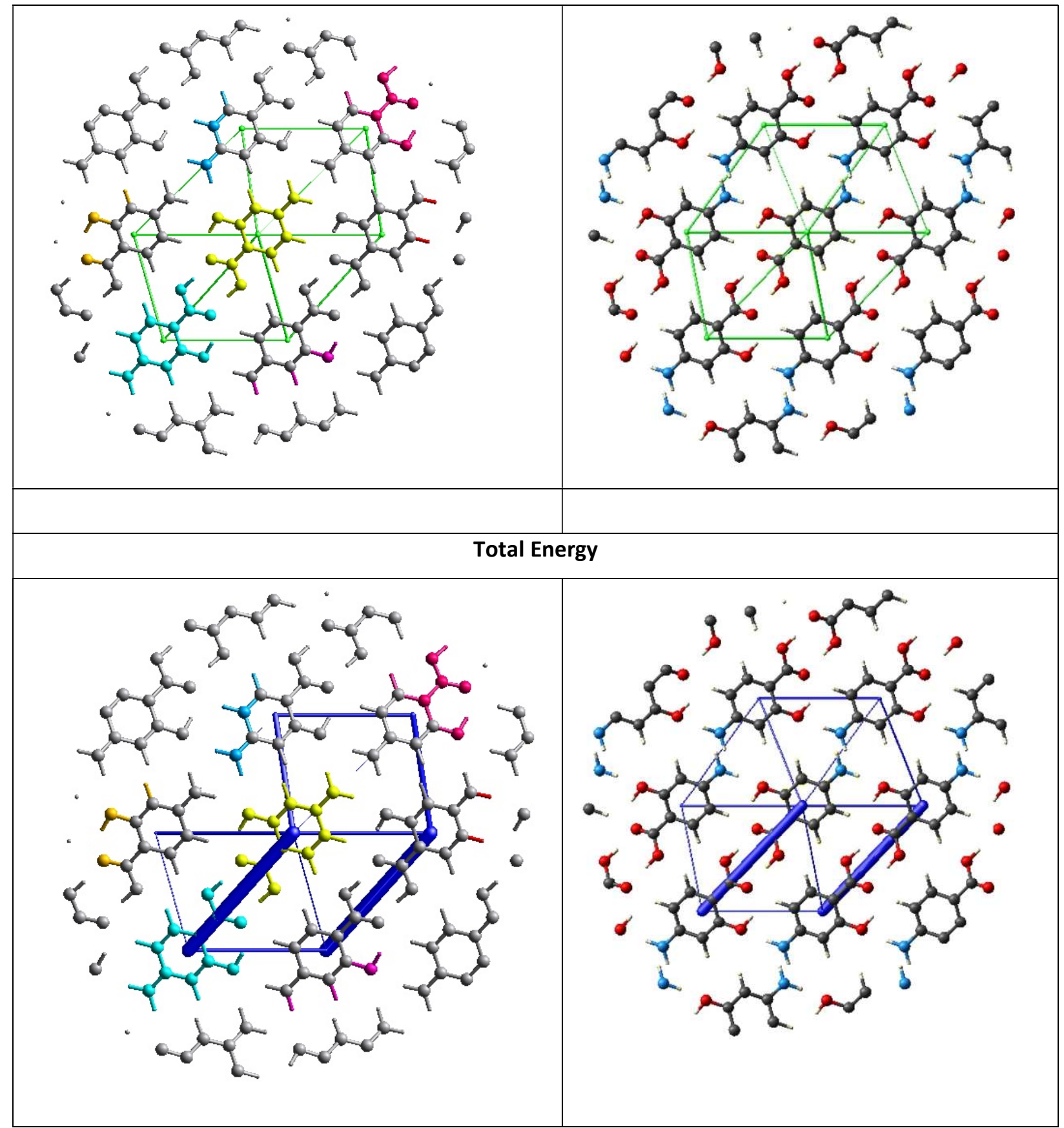

Figure 6. Dispersion energy frameworks between experimental and predicted crystal structures.

The crystal is viewed down the a axis. (A cylinder scale of 80 was used for all three energies). 
Table 7. PIXEL lattice energies $(\mathrm{kJ} / \mathrm{mol})$ for experimental and predicted STR 1 crystal structures.

\begin{tabular}{|ccc|}
\hline term & Exper. & Predicted \\
\hline$E_{\text {coul }}$ & -88.3 & -116.9 \\
$E_{\text {pol }}$ & -40.7 & -54.2 \\
$E_{\text {Disp }}$ & -109.4 & -121.7 \\
$E_{\text {Rep }}$ & 112.3 & 174.4 \\
\hline$E_{\text {total }}$ & -126.0 & -118.4 \\
\hline
\end{tabular}

Table 8: PIXEL energies $(\mathrm{kJ} / \mathrm{mol})$ for predicted STR1 structure (first line) and experimental (second line) between the molecular pairs. ${ }^{\mathrm{p}}$ and ${ }^{\mathrm{e}}$ in last column: predicted or experimental structure only. $E_{\text {int }}=E_{\text {dimer }}-2 E_{\text {monomer. }}$ The strong $E_{\text {coul }}$ values are highlighted in bold.

\begin{tabular}{|c|c|c|c|c|c|c|c|c|}
\hline $\begin{array}{c}\text { S.N } \\
\text { o }\end{array}$ & $\begin{array}{l}\text { Symm. } \\
\text { code }\end{array}$ & $\begin{array}{l}\text { Centroid } \\
\text { distance }\end{array}$ & $E_{\text {coul }}$ & $E_{\mathrm{pol}}$ & $E_{\text {Disp }}$ & $E_{\text {Rep }}$ & $E_{\text {total }}$ & Main interactions \\
\hline \multirow[t]{2}{*}{$\# 1$} & $-x+1 / 2, y+1 / 2$, & 7.027 & -6.5 & -1.7 & -7.2 & 2.1 & -13.3 & $\mathrm{C} 4-\mathrm{H} 1 \ldots \mathrm{O} 1$ \\
\hline & $-z+1 / 2$ & 6.733 & -21.3 & -6.4 & -17.8 & 14.0 & -31.6 & N1-H5...O1 \\
\hline \multirow[t]{2}{*}{$\# 2$} & $-\mathrm{x},-\mathrm{y}-1$, & 6.63 & -1.8 & -1.1 & -10.5 & 4.4 & -9.0 & $\mathrm{C} 5-\mathrm{H} 2 \ldots \mathrm{O} 2$ \\
\hline & $-z+2$ & 6.277 & -0.2 & -2.0 & -17.5 & 8.6 & -11.0 & $\mathrm{C} 6-\mathrm{H} 3 \ldots \mathrm{O} 22^{\mathrm{e}}$ \\
\hline \multirow[t]{2}{*}{3} & $-\mathrm{x},-\mathrm{y},-\mathrm{z}+2$ & 6.294 & -2.7 & -3.8 & -16.8 & 14.4 & -8.9 & $\mathrm{C} 5-\mathrm{H} 2 \ldots \mathrm{O} 2$ \\
\hline & & 6.927 & -0.2 & -1.1 & -9.8 & 3.5 & -7.5 & $\mathrm{H} 2 \ldots \mathrm{H} 2$ \\
\hline \multirow[t]{3}{*}{4} & $\mathrm{x}-1, \mathrm{y}, \mathrm{z}$ & 7.000 & -13.0 & -9.0 & -18.8 & 24.9 & -15.9 & C6-H3_..O3 \\
\hline & & & & 27 & 125 & 61 & & $\begin{array}{l}\mathrm{C} 6-\mathrm{H} 3 \ldots \mathrm{O} \\
\mathrm{N} 1-\mathrm{H} 4 \ldots \mathrm{O} 1\end{array}$ \\
\hline & & & & -2.1 & & & & $\mathrm{H} 3 \ldots \mathrm{H} 6$ \\
\hline \multirow[t]{2}{*}{5} & $\mathrm{x}-1, \mathrm{y}+1, \mathrm{z}$ & 7.918 & -9.1 & -2.2 & -8.3 & 4.7 & -14.9 & $\mathrm{~N} 1-\mathrm{H} 4 \ldots \mathrm{O} 1$ \\
\hline & & 8.052 & -4.2 & -1.0 & -5.7 & 1.0 & -9.8 & C6-H3...O3 \\
\hline \multirow[t]{2}{*}{6} & $-\mathrm{x}-1 / 2, \mathrm{y}-1 / 2$ & 8.625 & -30.9 & -16.1 & -21.9 & 55.9 & -13.0 & N1-H5...N1 \\
\hline & $-z^{+1 / 2}+1$ & 3.728 & 2.5 & -3.8 & -34.3 & 22.8 & -12.7 & \\
\hline \multirow[t]{2}{*}{7} & $-\mathrm{x}+1,-\mathrm{y}-1$ & 8.076 & -100.5 & -47.3 & -19.6 & 106.3 & -61.1 & $\mathrm{O} 2-\mathrm{H} 7 \ldots \mathrm{O} 3$ \\
\hline & $-z+2$ & 7.965 & -113.9 & -55.3 & -22.4 & 120.3 & -71.3 & $\mathrm{O} 2-\mathrm{H} 7 \ldots \mathrm{O} 2$ \\
\hline \multirow[t]{3}{*}{8} & $\mathrm{x}, \mathrm{y}+1, \mathrm{z}$ & 3.700 & -1.8 & -5.0 & -34.5 & 24.1 & -17.2 & $\begin{array}{l}\mathrm{N} 1 \ldots \mathrm{C} 3 ; \mathrm{C} 6 \ldots \mathrm{C} 5 \\
\mathrm{C} 1 \ldots \mathrm{O} 3 ; \mathrm{C} 4 \ldots \mathrm{C} 2\end{array}$ \\
\hline & & & & & & & & $\begin{array}{l}\mathrm{O} 3 \ldots \mathrm{O} 2^{\mathrm{p}} \\
\mathrm{O} 3 \ldots \mathrm{C} 7^{p}\end{array}$ \\
\hline & & 3.728 & 2.5 & -3.8 & -34.3 & 22.8 & -12.7 & $\mathrm{~N} 1-\mathrm{H} 5 \ldots \mathrm{N} 1{ }^{\mathrm{e}}$ \\
\hline
\end{tabular}

\subsection{Molecular electrostatic potential}

The Molecular ElectroStatic Potential (MESP) calculated in vacuo for both experimental and predicted structures is shown in the Fig. $7 \mathrm{a}$ and $7 \mathrm{~b}$ respectively. The MESP reveals the polar 
nature of the molecule, which is characterized by $V_{\mathrm{smax}}$, positive and $V_{\mathrm{smin}}$, negative extrema of potentials on the molecular surface [17]. For the predicted structure, it is noted that a strongest positive potential of about $+15.52 \mathrm{kcal} / \mathrm{mol}$ if found near the phenol hydrogen atom H6. Similar potential is found near the $\mathrm{NH}_{2}$ group and the $\mathrm{COOH}$ hydrogen atom $\mathrm{H} 7$ with $V_{\text {smax }}$ values +15.48 and $+15.36 \mathrm{kcal} / \mathrm{mol}$ respectively. The region between the less polar $\mathrm{H}-\mathrm{C}$ atoms $(\mathrm{H} 2, \mathrm{H} 3)$ has a smaller local maximum at $+13.8 \mathrm{kcal} / \mathrm{mol}$

As expected, the oxygen atoms of the carboxylic group $(\mathrm{O} 2, \mathrm{O} 3)$ and phenol group $(\mathrm{O} 1)$ display strong negative potentials $\left(V_{\mathrm{smin}}\right)$ with values $-11.3,-10.2$ and $-10.2 \mathrm{kcal} / \mathrm{mol}$ respectively, which exhibit their high hydrogen bond acceptor capability.

The above discussed potential values are in good agreement with those calculated for the experimental X-ray structure. The hydrogen bond donor capability is exposed from the positive charge accumulation located on the $-\mathrm{NH}_{2}$ and $\mathrm{O}-\mathrm{H}$ groups and all these characteristics are consistent with the molecular self-assembly.

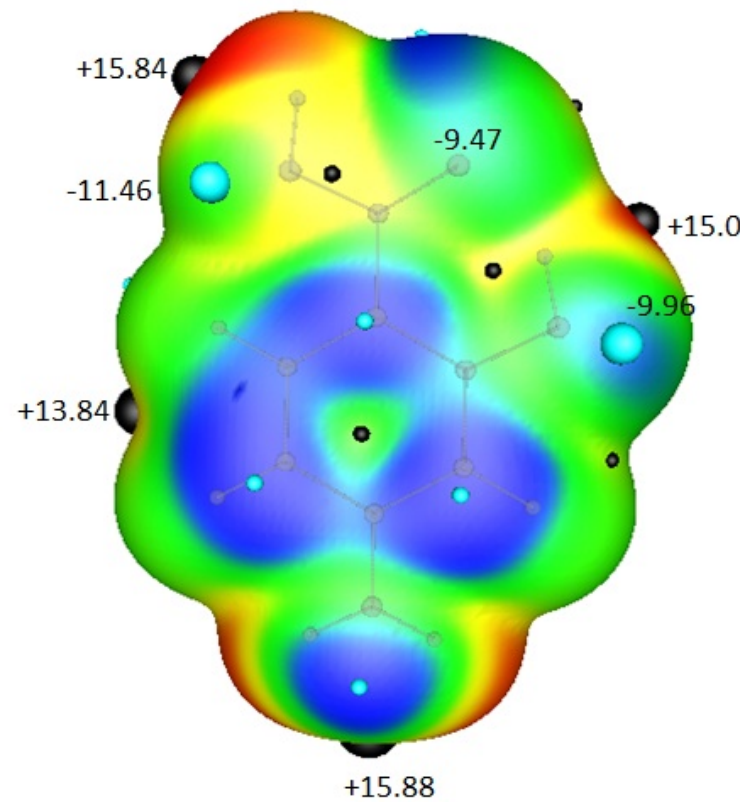

(a)

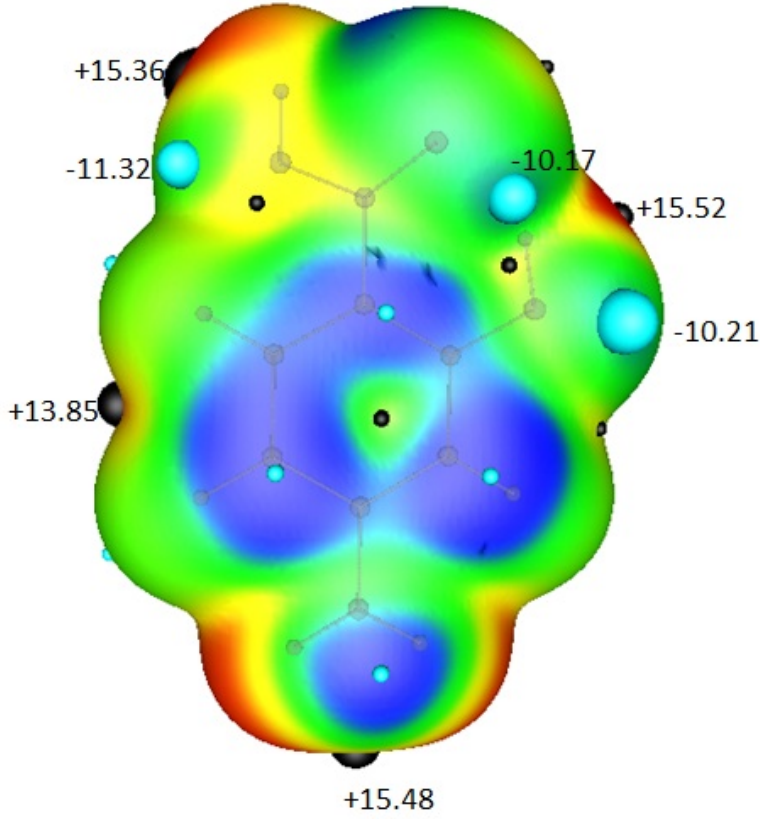

(b)

Fig 7: Molecular electrostatic potential on the AMSA molecule mapped over the electron density isosurface at 0.001 au. (a) Experiment and (b) Predicted structure. The positive $\left(V_{\mathrm{s}}, \max \right)$ and negative $(V \mathrm{~s}, \mathrm{~min})$ extrema of potentials are indicated by black and blue spheres, respectively. Values are in $\mathrm{kcal} / \mathrm{mol} / \mathrm{e}$. 


\subsection{Analysis of the predicted crystal packings.}

An illustration of the predicted crystal packings is given in Fig. S6. Among the 31 predicted crystal structures, ten (including the STR1 close to real structure) display the $\mathrm{COOH} . . \mathrm{COOH}$ homo-synthon with double hydrogen bond, which has very favorable electrostatic energy. The CD structure with $Z^{\prime}=2$ has the two independent molecules forming a $(\mathrm{COOH})_{2}$ synthon; this is however not the case for the $\mathrm{CD}$ and $\mathrm{BF}$ structures with $\mathrm{Z}^{\prime}=2$.

Four other packings display strong hydrogen bonds between $\mathrm{COOH}$ groups but with only one $\mathrm{H}$ bond within a dimer (Fig. 8). Each $\mathrm{COOH}$ group form then two H-bonds with two different neighbor molecules to forms $\mathrm{O}=\mathrm{C}-\mathrm{O}-\mathrm{H} . . \mathrm{O}=\mathrm{C}-\mathrm{O}-\mathrm{H}$ chains in the crystal.

Table 9. Properties of the different predicted crystal packings. The correlation coefficient is between $V_{\text {int }}$, the inner ESP and $V_{\text {out }}$, the ESP generated by the immediate molecular neighbors. The lattice electrostatic energy $E_{\text {elec }}$ is computed after ELMAM2 database transfer.

For packings which display translations along a short unit cell axis $(<3.8 \AA)$, the column "Parallel displaced" yields the inter-planar distance $d$. The relative displacement of the molecule is shown in the next column.

Four packings show stacking of molecules related by $2_{1}$ helical rotation or roto-inversion along a unit cell axis of around $7 \AA$ (underlined); the unit cell parameter, corresponding to two stacking layers is here given.

The last column indicates if the $(\mathrm{COOH})_{2}$ synthon is present $(\mathrm{Y})$ or not $(/)$ in the crystal structure; " $1 \mathrm{HB}$ " refers to $\mathrm{O}=\mathrm{C}-\mathrm{C}-\mathrm{O}-\mathrm{H} . . . \mathrm{O}=\mathrm{C}-\mathrm{C}-\mathrm{O}-\mathrm{H}$ chains.

\begin{tabular}{|cccc|cc|c|}
\hline crystal & ID & $\begin{array}{c}\text { Correl. } \\
\left(V \text { int }, V_{\text {ext }}\right)\end{array}$ & $\begin{array}{c}E_{\text {elec }} \\
\mathrm{kJ} / \mathrm{mol}\end{array}$ & $\begin{array}{l}/ / \text { displaced } \\
d(\AA)\end{array}$ & $\begin{array}{c}\text { Displace- } \\
\text { ment }(\AA)\end{array}$ & $\begin{array}{c}(\mathrm{COOH})_{2} \\
\text { synthon }\end{array}$ \\
\hline EXP & EXP & -0.290 & -266 & 3.445 & 1.42 & $\mathrm{Y}$ \\
\hline Str 1 & FC & -0.230 & -257 & 3.466 & 1.20 & $\mathrm{Y}$ \\
\hline str 2 & DC & -0.123 & -245 & 3.571 & 0.35 & $\mathrm{Y}$ \\
str 3 & AU & -0.270 & -243 & 3.489 & 1.28 & $/$ \\
str 4 & FA & 0.178 & -235 & 3.598 & 0.30 & $\mathrm{Y}$ \\
str 5 & AQ & -0.525 & -282 & 3.515 & 0.97 & $1 \mathrm{HB}$ \\
str 6 & AY & -0.468 & -221 & 3.531 & 0.83 & $/$ \\
str 7 & DA & -0.447 & -200 & 3.566 & 0.29 & $/$ \\
str 8 & AH & 0.008 & -208 & 3.563 & 0.27 & $/$ \\
str 9 & AF & -0.241 & -218 & 3.486 & 0.90 & $1 \mathrm{HB}$ \\
str 10 & AK & -0.283 & -252 & 3.472 & 1.36 & $\mathrm{Y}$ \\
str 11 & AA & -0.185 & -139 & 3.572 & 0.23 & $/$ \\
str 12 & AV & -0.340 & -245 & 3.351 & 1.55 & $/$ \\
str 13 & AM & -0.702 & -239 & $\underline{7.10}$ & $/$ & $\mathrm{Y}$ \\
str 14 & AZ & -0.070 & -225 & 3.515 & 0.96 & $1 \mathrm{HB}$
\end{tabular}




\begin{tabular}{|cccc|cc|c|}
$\operatorname{str} 15$ & $\mathrm{AB}$ & -0.565 & -217 & $\underline{7.73}$ & $/$ & $/$ \\
$\mathrm{str} 16$ & $\mathrm{DB}$ & -0.236 & -205 & 3.408 & 1.18 & $/$ \\
$\mathrm{str} 17$ & $\mathrm{AS}$ & -0.449 & -181 & 3.608 & 0.30 & $/$ \\
$\mathrm{str} 18$ & $\mathrm{CB}$ & -0.810 & -251 & $/$ & $/$ & $/$ \\
$\mathrm{str} 19$ & $\mathrm{AP}$ & -0.091 & -217 & 3.408 & 1.32 & $\mathrm{Y}$ \\
$\mathrm{str} 20$ & $\mathrm{BA}$ & -0.080 & -219 & 3.409 & 1.33 & $\mathrm{Y}$ \\
$\mathrm{str} 21$ & $\mathrm{BB}$ & -0.088 & -220 & 3.410 & 1.32 & $\mathrm{Y}$ \\
$\mathrm{str} 22$ & $\mathrm{CD}$ & -0.480 & -235 & $/$ & $/$ & $\mathrm{Y}$ \\
$\mathrm{str} 23$ & $\mathrm{AI}$ & -0.424 & -243 & $/$ & $/$ & $\mathrm{Y}$ \\
$\mathrm{str} 24$ & $\mathrm{BH}$ & -0.179 & -170 & 3.588 & 1.17 & $/$ \\
$\mathrm{str} 25$ & $\mathrm{BD}$ & -0.284 & -185 & $/$ & $/$ & $/$ \\
$\mathrm{str} 26$ & $\mathrm{DE}$ & -0.024 & -208 & $/$ & $/$ & $/$ \\
$\mathrm{str} 27$ & $\mathrm{CA}$ & -0.713 & -185 & $\underline{6.96}$ & $/$ & $/$ \\
$\underline{s t r} 28$ & $\mathrm{CE}$ & -0.777 & -217 & $/$ & $/$ & $/$ \\
$\underline{\mathrm{str} 29}$ & $\mathrm{BF}$ & 0.463 & -69 & 3.507 & 1.27 & $/$ \\
$\mathrm{str} 30$ & $\mathrm{CC}$ & 0.153 & -100 & $\underline{7.12}$ & $/$ & $1 \mathrm{HB} /$ weak \\
$\operatorname{str} 31$ & $\mathrm{DD}$ & -0.244 & -174 & $/$ & $/$ & $/$ \\
\hline
\end{tabular}

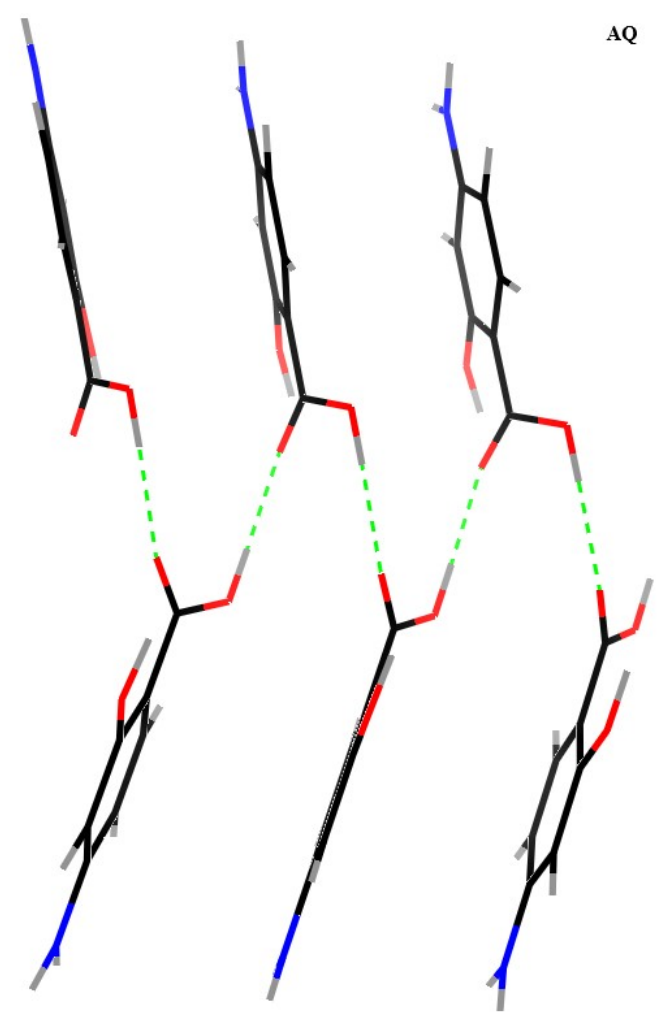


Figure 8. Auto-stereogram of AQ packing showing the chain of hydrogen bonds between $\mathrm{COOH}$ groups. The $\mathrm{O}$...H distance is $1.836 \AA$. The distance between parallel aromatic planes is $3.514 \AA$ while the unit cell translation vector length is $c=3.6445 \AA$.

The two packings with strongest $U_{\text {lattice }}$ (STR1 $=\mathrm{FC}^{*}$ and DC around $-131 \mathrm{~kJ} / \mathrm{mol}$ ) belong to the group with $(\mathrm{COOH})_{2}$ synthon (Fig. S3, Table 1 and 9). In the group of packings which have the

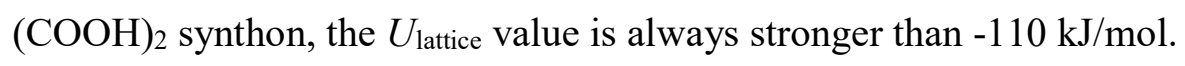

The three packings (AQ, AF, AZ) with strong chains of $\mathrm{O}=\mathrm{C}-\mathrm{O}-\mathrm{H} . . . \mathrm{O}=\mathrm{C}-\mathrm{O}-\mathrm{H}$ hydrogen bond

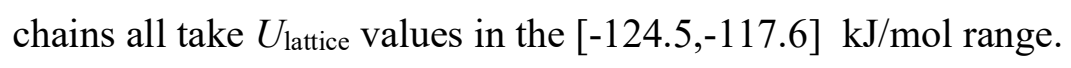

The eight packings with weakest $U_{\text {lattice }}$ values belong all to the "none" group having no hydrogen bond between $\mathrm{COOH}$ moieties. Several packings with no H-bond between $\mathrm{COOH}$ group have however strong $U_{\text {lattice }}$ values reaching $-125 \mathrm{~kJ} / \mathrm{mol}$ for AU.

As the molecule is nearly planar and is formed by an aromatic ring bearing hetero-atoms, it is likely to form stacking interactions $[31,35,36]$. Among the 31 predicted crystal structure, twenty are involved in parallel displaced stacking via a translation of short unit cell axis, whose length is in the 3.573-3.733 $\AA$ range. The inter-planar distance is in the 3.351-3.608 $\AA$ range and parallel displacements are between 0.230 and $1.552 \AA$. The real crystal packing belongs to this subgroup and shows one of the largest displacement at $1.42 \AA$.

Extensive stacking occurs in four additional crystal structures at distance $\sim 3.5 \AA$ where the molecules are related by 2-fold helical axis or roto-inversion (AM, AB, CA, CC, Table 9). Application of the symmetry operation twice leads to a translation of unit cell vector of about 7 $\AA$.

$E_{\text {elec}}$, the electrostatic contribution to the lattice energy, computed from the electron density multipolar model transferred from ELMAM2 database, is shown in Table 9. The $E_{\text {elec }}$ and $U_{\text {lattice }}$ values are $63 \%$ correlated. The real crystal structure comes in second position as strongest $E_{\text {elec }}$ lattice value, while the predicted close to real STR1 structure is in third position.

The crystal AQ has the strongest $E_{\text {elec }}$ value, it has indeed strong hydrogen bonds, chains of $\mathrm{O}=\mathrm{C}$ $\mathrm{O}-\mathrm{H} . . \mathrm{O}=\mathrm{C}-\mathrm{O}-\mathrm{H}$ hydrogen bonds along the $\mathbf{c}$ unit cell axis (Fig. 8). One hydrogen atom of the $\mathrm{NH}_{2}$ group forms two bifurcated hydrogen bond towards two $\mathrm{C}=\mathrm{O}$ carbonyl groups while the other $\mathrm{H}$ atoms is $\mathrm{H}$-bonded to two hydroxyl groups. The $\mathrm{NH}_{2}$ group has therefore one more $\mathrm{H}$ - 
bond partner in AQ packing than in the real crystal where one strong $\left(d_{\mathrm{OH}}=2.246\right)$ and two longer $\left(d_{\mathrm{OH}}=2.634\right.$ and $\left.3.045 \AA\right) \mathrm{N}-\mathrm{H} . . . \mathrm{O}$ interactions occur.

\section{Complementarity of electrostatic potential in the packings.}

Electrostatic potentials mapped on Hirshfeld surfaces provide direct insight into intermolecular interactions in crystals [37]. The experimental crystal shows a correlation $C_{\mathrm{vv}}$ of $-29 \%$ between the interior and exterior potential (Fig. 9). The regions of highest inner potential correspond to the polar hydrogen atom $\mathrm{Ho}$ and $\mathrm{Hn}$ while oxygen atoms are at the origin of the most electronegative areas. A high anti-correlation is related to a good complementarity of inner and outer potentials. Some predicted packings such as $\mathrm{CE}$ reach much stronger anti-correlations $(c=-$ 0.777); CE has two molecules per asymmetric unit.

Three crystals have a positive (unfavorable) $C v v$ correlation between $V_{\text {int }}$ and $V_{\text {ext. }}$ The worst is crystal $\mathrm{BF}$ (with $Z$ '=2) where $\mathrm{NH}_{2}$ interacts with two other $\mathrm{NH}_{2}$ groups and with the hydroxyl hydrogen atom (Fig. S4). Crystal FA has a positive $C_{\mathrm{Vv}}$ correlation +0.178 which may be explained by a parallel stacking with low // displacement $(0.30 \AA)$ which results in atoms being in contact with themselves (unfavorable electrostatic contacts) and moreover the electropositive $\mathrm{NH}_{2}$ interacts with two other $\mathrm{NH}_{2}$ groups.

While the $\left(V_{\text {int }}, V_{\text {ext }}\right)$ correlation indicator does not discriminate the real crystal among the best predicted packings, it evidences some unrealistic features in some of them. 


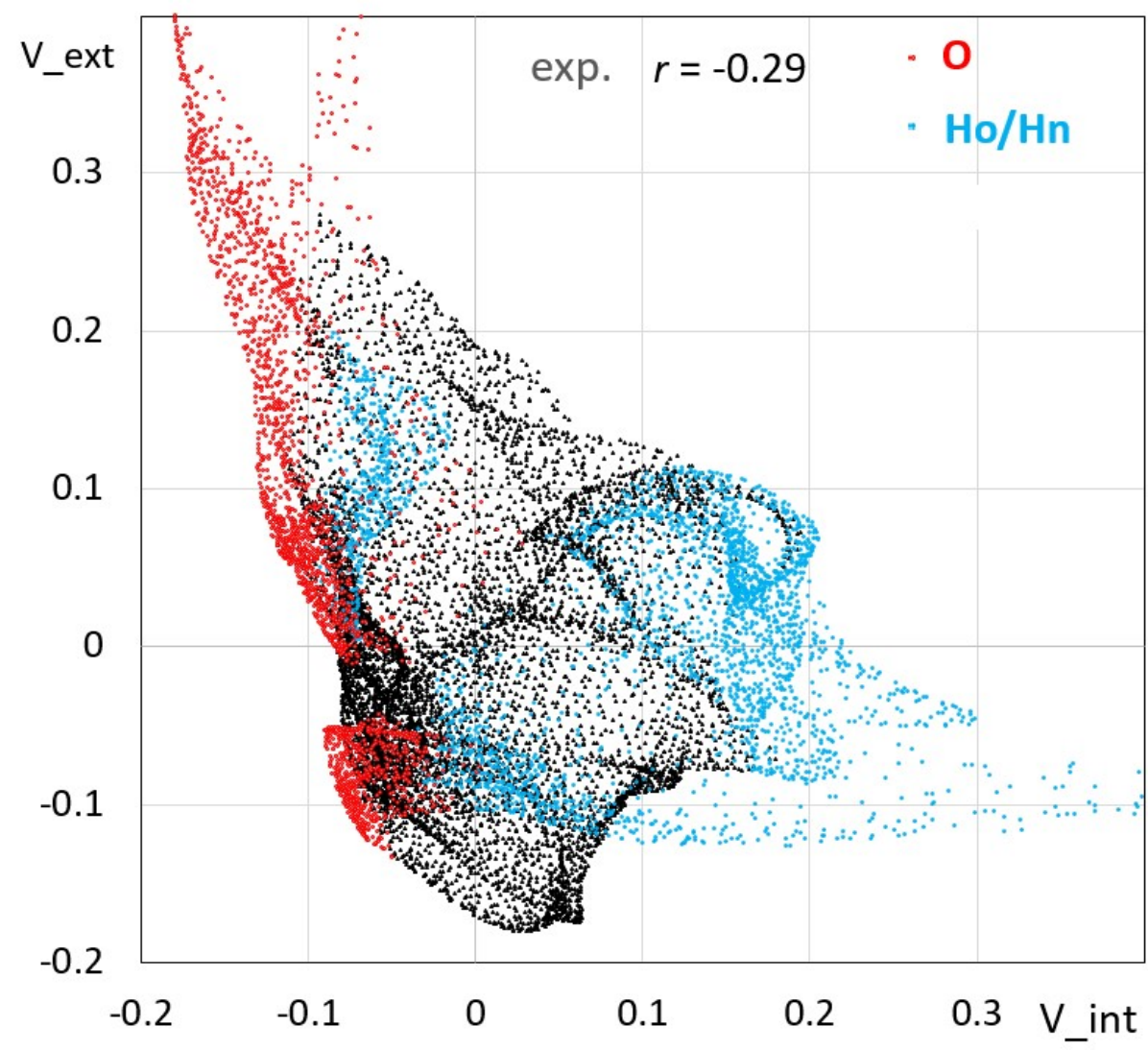

Figure 9. Scatterplot of inner and outer electrostatic potential $V$ on the Hirshfeld surface for the experimental crystal structure. The contacts donated by oxygen and by the polar hydrogen atom $\mathrm{Ho} / \mathrm{n}$ from the inner molecule are highlighted in red and blue color, respectively. The electrostatic potential was computed from the multipolar model derived from ELMAM2 database transfer [24]. The outer potential $V_{\text {ext }}$ was computed from the 14 neighbor molecules in contact with the central one. 


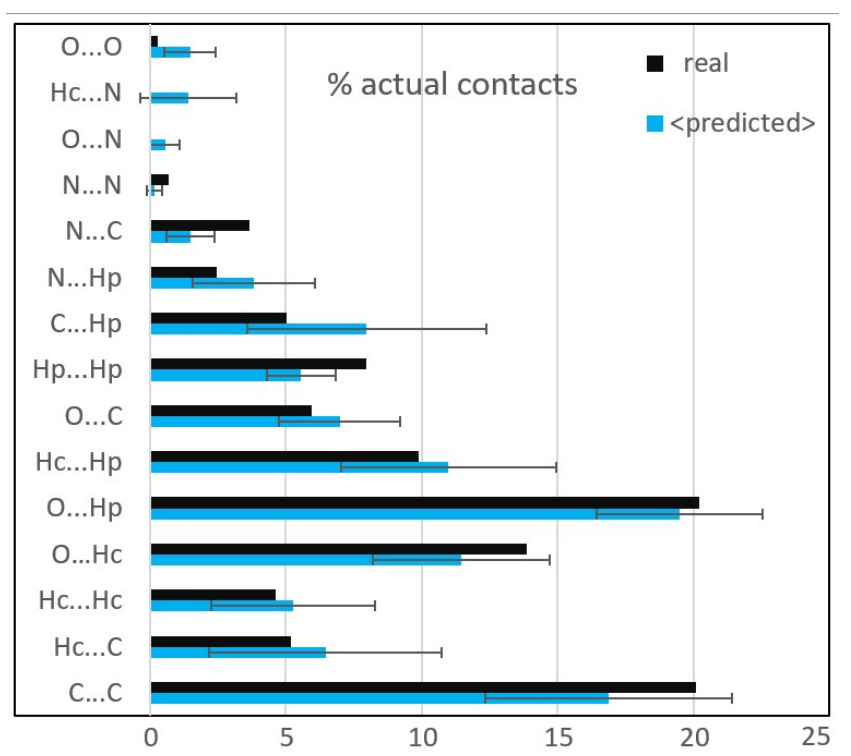

Figure 10. Average percentage $C_{\mathrm{xy}}$ of actual contacts on the Hirshfeld surface in the predicted crystal packings (in blue). The values for the real packing are shown in black. The errors bars represent the standard deviation in the sample of predicted structures. Hc and Hp (polar) represent hydrogen atoms bound to $\mathrm{C}$ and $\mathrm{N} / \mathrm{O}$ respectively.

In terms of contact types, the difference between the real crystal and predicted ones can be seen in Fig. 10 and S5. The real crystal is more involved in C...C stacking and weak hydrogen bonds of O...Hc type, compared to the average in the predicted structures. On average, the amount of strong hydrogen bonds $\mathrm{O} \ldots \mathrm{Hp}(\mathrm{O} \ldots \mathrm{H}-\mathrm{N}$ and $\mathrm{O} \ldots \mathrm{H}-\mathrm{O})$ contacts in the predicted packings is very close to the real crystal $(19.5 \pm 3.3$ vs. $20.2 \%)$ while the non-polar contacts Hc...Hc and Hc...C $(\mathrm{C}-\mathrm{H} . . . \pi$ interactions) are very slightly less represented.

\section{Conclusion}

The ab initio prediction of the possible crystal packings of AMSA molecule, commenced by a gas phase optimization using the DFT level approach, was found to be valid. The global search for the hypothetical conformers of the AMSA compound successfully generated possible dense packings within the repulsion alone potential field. The inner lattice minimization was carried out with repulsion-dispersion field. The predicted crystal structure with lowest lattice energy, generated in $\mathrm{P} 2{ }_{1} / \mathrm{c}$ space group, was found to be close to the experimental thermodynamically stable one. The experimental crystal is notably stabilized by a double hydrogen bond forming a $(\mathrm{COOH})_{2}$ synthon and parallel displaced cycle stacking. These two dimers have the highest interaction energy. The Hirshfeld surface reveals the contribution of the prior interactions towards crystal stability. The chemical bonding characteristics of closed shell interactions were 
thoroughly investigated by QTAIM approach and the reactive nature of the global minimum was exploited from the electrostatic potential analysis. The 31 predicted crystal structures were analyzed and compared through several descriptors. The EXP crystal structure has the second strongest lattice electrostatic energy. Concerning the $V_{\text {int }}$ and $V_{\text {ext }}$ electrostatic potentials on the Hirshfeld surface, about one third of the predicted structures displayed a better complementarity than the EXP crystal, but this indicator can pinpoint some awkward packings.

\section{Acknowledgements.}

\section{Compliance with ethical standards}

Conflict of interest: The authors declare that they have no conflict of interest.

Ethical statement: All ethical guidelines have been adhered.

\section{References}

[1] H. Liu, F. Wang, G. Wang, X. Gong, Theoretical studies on the structures, densities, detonation properties and thermal stability of 2,4,6-trinitropyridineN-oxide (TNPyO) and its derivatives, Molecular Simulation 39(2) (2013) 123-128.

[2] G. Bauer, A. Lange, N. Gribova, C. Holm, J. Gross, Effective potentials between gold nano crystals functional dependence on temperature, Molecular Simulation 41(14) (2014) 1153-1158.

[3] M.A. Bailey, M.J. Ingram, D.P. Naughton, K.J. Rutt, H.T. Dodd, Aminosalicylic acid conjugates of EDTA as potential anti-inflammatory pro-drugs: synthesis, copper chelation and superoxide dismutaselike activities, Transition Metal Chemistry 33(2) (2007) 195-202.

[4] M.R. O'Donnell, N. Padayatchi, J.Z. Metcalfe, Elucidating the role of clofazimine for the treatment of tuberculosis, The International Journal of Tuberculosis and Lung Disease 20(12) (2016) 52-57.

[5] S. Zhuang, W. Liu, Investigation of the binding specificity of Erbin-PDZ affinity clamp by molecular dynamics simulations, Computational and Theoretical Chemistry 963(2-3) (2011) 448-452.

[6] J. Thun, M. Schoeffel, J. Breu, Crystal structure prediction could have helped the experimentalists with polymorphism in benzamide, Molecular Simulation 34(10-15) (2008) 1359-1370.

[7] R. Montis, M.B. Hursthouse, Surprisingly complex supramolecular behaviour in the crystal structures of a family of mono-substituted salicylic acids, CrystEngComm 14(16) (2012) 5242.

[8] P. Geerlings, F. De Proft, W. Langenaeker, Conceptual Density Functional Theory, Chemical Reviews 103(5) (2003) 1793-1874.

[9] M.J. Frisch, G.W. Trucks, H.B. Schlegel, G.E. Scuseria, M.A. Robb, J.R. Cheeseman, G. Scalmani, V. Barone, B. Mennucci, G.A. Petersson, H. Nakatsuji, M. Caricato, X. Li, H.P. Hratchian, A.F. Izmaylov, J. Bloino, G. Zheng, J.L. Sonnenberg, M. Hada, M. Ehara, K. Toyota, R. Fukuda, J. Hasegawa, M. Ishida, T. Nakajima, Y. Honda, O. Kitao, H. Nakai, T. Vreven, J.A. Montgomery, Jr., J.E. Peralta, F. Ogliaro, M. Bearpark, J.J. Heyd, E. Brothers, K.N. Kudin, V.N. Staroverov, R. Kobayashi, J. Normand, K. Raghavachari, A. Rendell, J.C. Burant, S.S. Iyengar, J. Tomasi, M. Cossi, N. Rega, N.J. Millam, M. Klene, J.E. Knox, J.B. Cross, V. Bakken, C. Adamo, J. Jaramillo, R. Gomperts, R.E. Stratmann, O. 
Yazyev, A.J. Austin, R. Cammi, C. Pomelli, J.W. Ochterski, R.L. Martin, K. Morokuma, V.G. Zakrzewski, G.A. Voth, P. Salvador, J.J. Dannenberg, S. Dapprich, A.D. Daniels, Ö. Farkas, J.B. Foresman, J.V.. Ortiz, J. Cioslowski, D.J. Fox, Gaussian09, J. Am. Stat. Assoc. (2009).

[10] J.R. Holden, Z. Du, H.L. Ammon, Prediction of possible crystal structures for C-, H-, N-, O-, and Fcontaining organic compounds, Journal of computational chemistry 14(4) (1993) 422-437.

[11] S.L. Price, M. Leslie, G.W.A. Welch, M. Habgood, L.S. Price, P.G. Karamertzanis, G.M. Day, Modelling organic crystal structures using distributed multipole and polarizability-based model intermolecular potentials, Physical Chemistry Chemical Physics 12(30) (2010) 8478.

[12] D.E. Williams, S.R. Cox, Nonbonded potentials for azahydrocarbons: the importance of the Coulombic interaction, Acta Crystallographica Section B Structural Science 40(4) (1984) 404-417.

[13] D.S. Coombes, S.L. Price, D.J. Willock, M. Leslie, Role of Electrostatic Interactions in Determining the Crystal Structures of Polar Organic Molecules. A Distributed Multipole Study, The Journal of Physical Chemistry 100(18) (1996) 7352-7360.

[14] A. Stone, The Theory of Intermolecular Forces, Oxford University Press2013.

[15] L.A. Curtiss, K. Raghavachari, J.A. Pople, Gaussian-2 theory using reduced Mo/ller-Plesset orders, The Journal of Chemical Physics 98(2) (1993) 1293-1298.

[16] F. Milstein, R. Hill, Divergences Among the Born and Classical Stability Criteria for Cubic Crystals under Hydrostatic Loading, Physical Review Letters 43(19) (1979) 1411-1413.

[17] F.A. Bulat, A. Toro-Labbé, T. Brinck, J.S. Murray, P. Politzer, Quantitative analysis of molecular surfaces: areas, volumes, electrostatic potentials and average local ionization energies, Journal of Molecular Modeling 16(11) (2010) 1679-1691.

[18] W.H. Eugen Schwarz, Richard F. Bader: Atoms in Molecules (A Quantum Theory) Clarendon Press 1990, Oxford. ISBN 019-855-1681, 438 pages, Preis: £50, Berichte der Bunsengesellschaft für physikalische Chemie 95(10) (1991) 1308-1308.

[19] W. Kutzelnigg, Atoms in Molecules. A Quantum Theory. (Reihe: International Series of Monographs on Chemistry, Vol. 22.) Von R.F.W. Bader. Clarendon Press, Oxford, 1990. XVIII, 438 S., geb. £ 50.00. - ISBN 0-19-855168-1, Angewandte Chemie 104(10) (1992) 1423-1423.

[20] J.-D. Chai, M. Head-Gordon, Systematic optimization of long-range corrected hybrid density functionals, The Journal of Chemical Physics 128(8) (2008) 084106.

[21] M.W. Schmidt, K.K. Baldridge, J.A. Boatz, S.T. Elbert, M.S. Gordon, J.H. Jensen, S. Koseki, N. Matsunaga, K.A. Nguyen, S. Su, T.L. Windus, M. Dupuis, J.A. Montgomery, General atomic and molecular electronic structure system, Journal of computational chemistry 14(11) (1993) 1347-1363.

[22] T. Lu, F. Chen, Multiwfn: A multifunctional wavefunction analyzer, Journal of computational chemistry 33(5) (2011) 580-592.

[23] N.K. Hansen, P. Coppens, Testing aspherical atom refinements on small-molecule data sets, Acta Crystallographica Section A 34(6) (1978) 909-921.

[24] S. Domagała, B. Fournier, D. Liebschner, B. Guillot, C. Jelsch, An improved experimental databank of transferable multipolar atom models - ELMAM2. Construction details and applications, Acta Crystallographica Section A Foundations of Crystallography 68(3) (2012) 337-351.

[25] F.H. Allen, I.J. Bruno, Bond lengths in organic and metal-organic compounds revisited:X-H bond lengths from neutron diffraction data, Acta Crystallographica Section B Structural Science 66(3) (2010) 380-386.

[26] C. Jelsch, B. Guillot, A. Lagoutte, C. Lecomte, Advances in protein and small-molecule chargedensity refinement methods usingMoPro, Journal of Applied Crystallography 38(1) (2005) 38-54.

[27] B. Guillot, E. Enrique, L. Huder, C. Jelsch, MoProViewer: a tool to study proteins from a charge density science perspective, Acta Crystallographica Section A Foundations and Advances 70(a1) (2014) C279-C279.

[28] L.J. Farrugia, WinGXandORTEP for Windows: an update, Journal of Applied Crystallography 45(4) (2012) 849-854.

[29] M.A. Spackman, J.J. McKinnon, Fingerprinting intermolecular interactions in molecular crystals, CrystEngComm 4(66) (2002) 378-392. 
[30] G.R. Desiraju, Supramolecular Synthons in Crystal Engineering-A New Organic Synthesis, Angewandte Chemie International Edition in English 34(21) (1995) 2311-2327.

[31] C. Jelsch, K. Ejsmont, L. Huder, The enrichment ratio of atomic contacts in crystals, an indicator derived from the Hirshfeld surface analysis, IUCrJ 1(Pt 2) (2014) 119-128.

[32] R.F.W. Bader, A quantum theory of molecular structure and its applications, Chemical Reviews 91(5) (1991) 893-928.

[33] E. Espinosa, I. Alkorta, I. Rozas, J. Elguero, E. Molins, About the evaluation of the local kinetic, potential and total energy densities in closed-shell interactions, Chemical Physics Letters 336(5-6) (2001) 457-461.

[34] F. Jensen, An Atomic Counterpoise Method for Estimating Inter- and Intramolecular Basis Set Superposition Errors, Journal of Chemical Theory and Computation 6(1) (2009) 100-106.

[35] L.M. Salonen, M. Ellermann, F. Diederich, Aromatic Rings in Chemical and Biological Recognition: Energetics and Structures, Angewandte Chemie International Edition 50(21) (2011) 4808-4842.

[36] C.R. Martinez, B.L. Iverson, Rethinking the term "pi-stacking", Chemical Science 3(7) (2012) 2191.

[37] M.A. Spackman, J.J. McKinnon, D. Jayatilaka, Electrostatic potentials mapped on Hirshfeld surfaces provide direct insight into intermolecular interactions in crystals, CrystEngComm (2008) 377-388. 


\section{Supplementary Materials.}

Table S1. Topological parameters at the bond critical points of predicted aminosalicyclic acid crystal structure [STR 1]: Electron density $\rho$, Laplacian $\nabla^{2} \rho$, Hessian eigenvalues, Ellipticity $\varepsilon$, Potential, Kinetic and Total energy density.

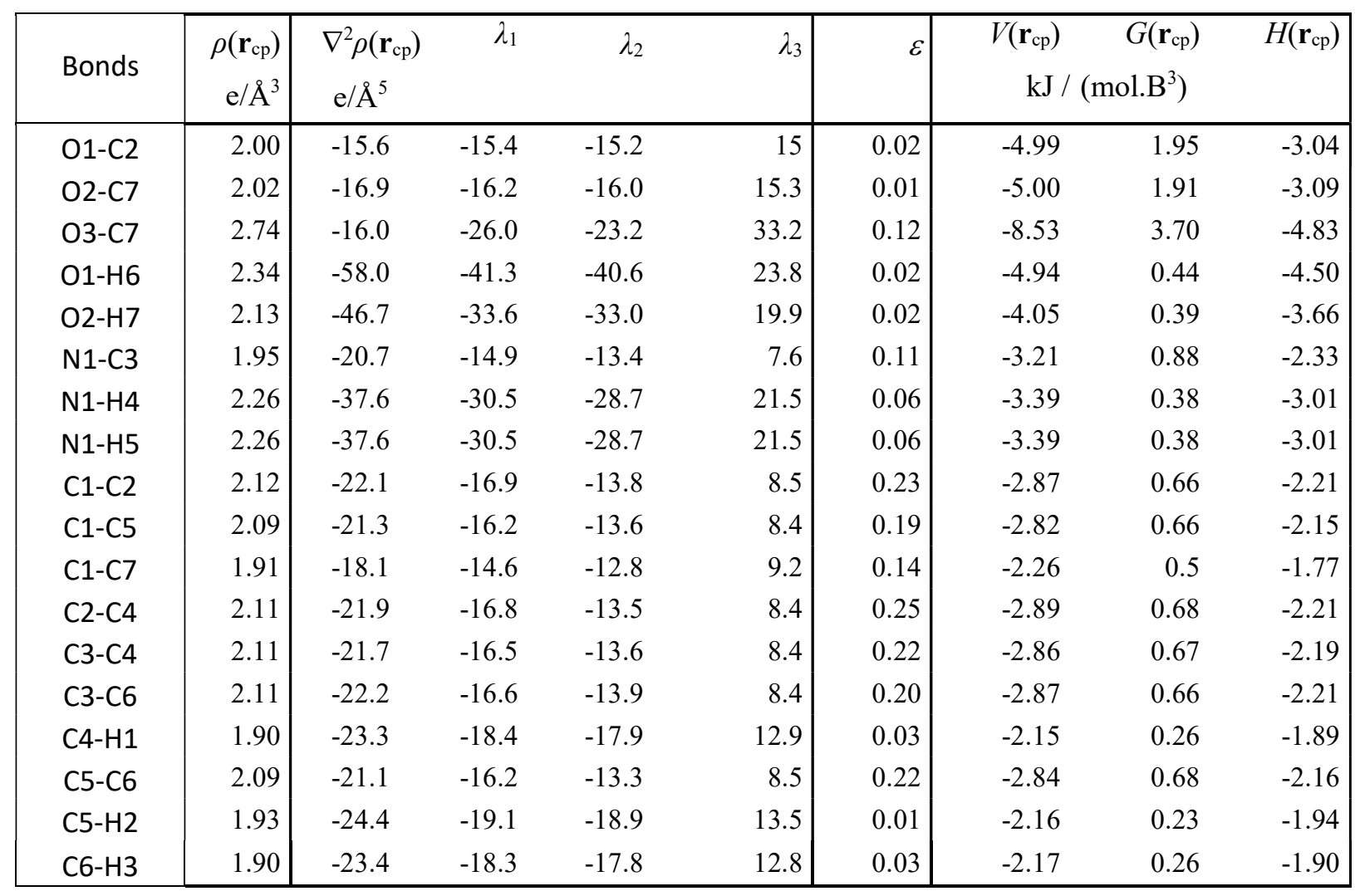


Topological parameters derived from ELMAM2 database transfer

\begin{tabular}{|c|l|cccc|l|}
\hline bond & $\rho_{\mathrm{bcp}}(\mathbf{r})$ & $\nabla^{2} \rho_{\mathrm{bcp}}(\mathbf{r})$ & $\lambda_{1}$ & $\lambda_{2}$ & $\lambda_{3}$ & $\varepsilon$ \\
& $\mathrm{e} / \AA^{3}$ & $\mathrm{e} / \mathrm{A} 5$ & & & & \\
\hline O1-C2 & 2.06 & -16.7 & -16.1 & -14.8 & 14.2 & 0.09 \\
O2-C7 & 2.37 & -19.3 & -20.1 & -17.4 & 18.2 & 0.16 \\
O3-C7 & 2.76 & -29.3 & -26.4 & -24.6 & 21.6 & 0.08 \\
O1-H6 & 2.44 & -52.2 & -41.4 & -40.7 & 29.8 & 0.02 \\
O2-H7 & 2.47 & -55.6 & -42.8 & -42.7 & 29.9 & 0.00 \\
N1-C3 & 1.92 & -12.7 & -14.7 & -11.9 & 13.9 & 0.23 \\
N1-H4 & 2.26 & -38.1 & -32.1 & -30.5 & 24.5 & 0.05 \\
N1-H5 & 2.26 & -38.1 & -32.1 & -30.5 & 24.5 & 0.05 \\
C1-C2 & 2.13 & -18.8 & -16.4 & -13.2 & 10.8 & 0.24 \\
C1-C5 & 2.07 & -17.6 & -15.6 & -12.9 & 10.9 & 0.21 \\
C1-C7 & 1.92 & -15.4 & -14.3 & -12.2 & 11.1 & 0.18 \\
C2-C4 & 2.19 & -20.0 & -17.0 & -13.7 & 10.7 & 0.24 \\
C3-C4 & 2.11 & -18.2 & -16.1 & -12.9 & 10.8 & 0.25 \\
C3-C6 & 2.11 & -18.2 & -16.1 & -12.9 & 10.8 & 0.25 \\
C4-H1 & 1.88 & -19.8 & -18.0 & -17.0 & 15.2 & 0.06 \\
C5-C6 & 2.13 & -18.8 & -16.1 & -13.4 & 10.7 & 0.21 \\
C5-H2 & 1.87 & -19.8 & -18.0 & -17.0 & 15.2 & 0.06 \\
C6-H3 & 1.87 & -19.8 & -18.0 & -17.0 & 15.2 & 0.06 \\
\hline
\end{tabular}
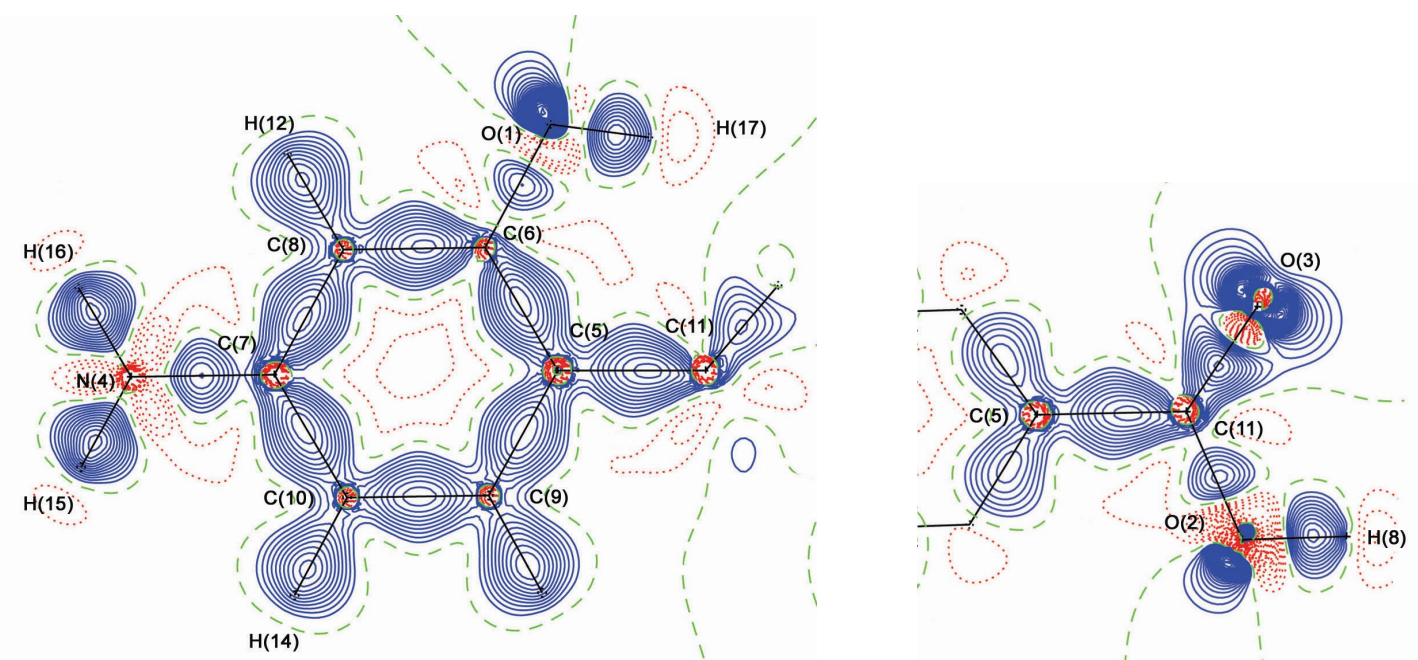

Figure S1. Deformation density of predicted AMSA [STR1], obtained with software Wfn2plot and Denprop 

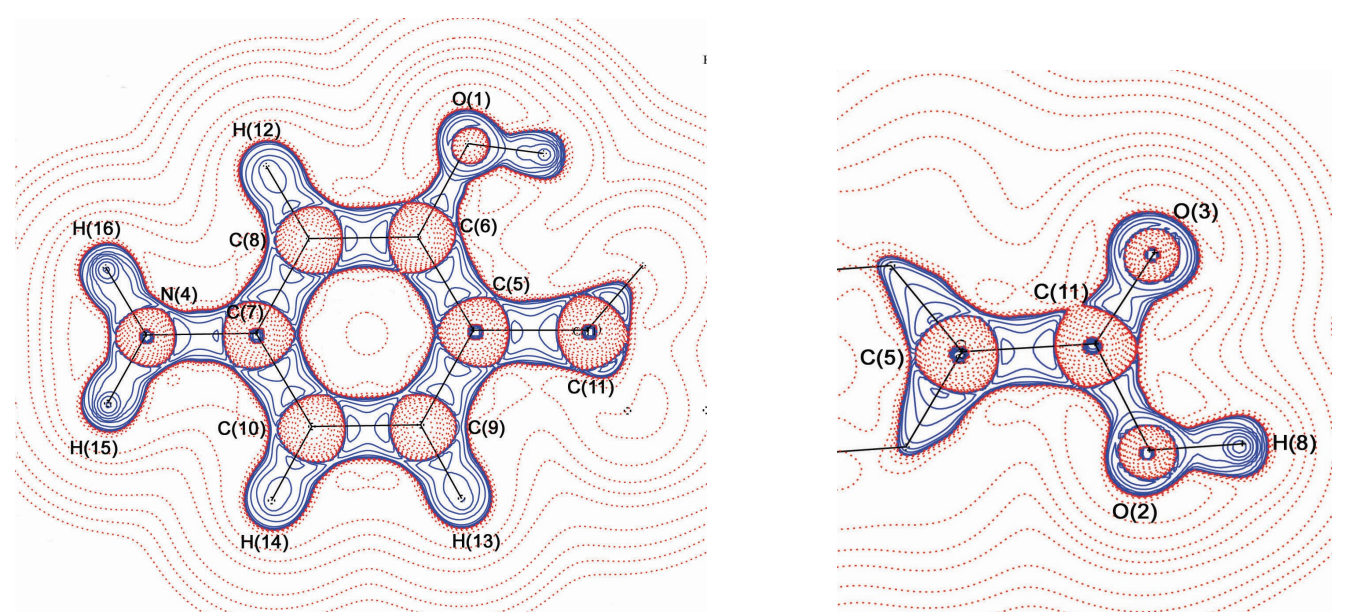

Figure S2. Laplacian of electron density of predicted AMSA [str 1] in the aromatic cycle and in the COO group planes.

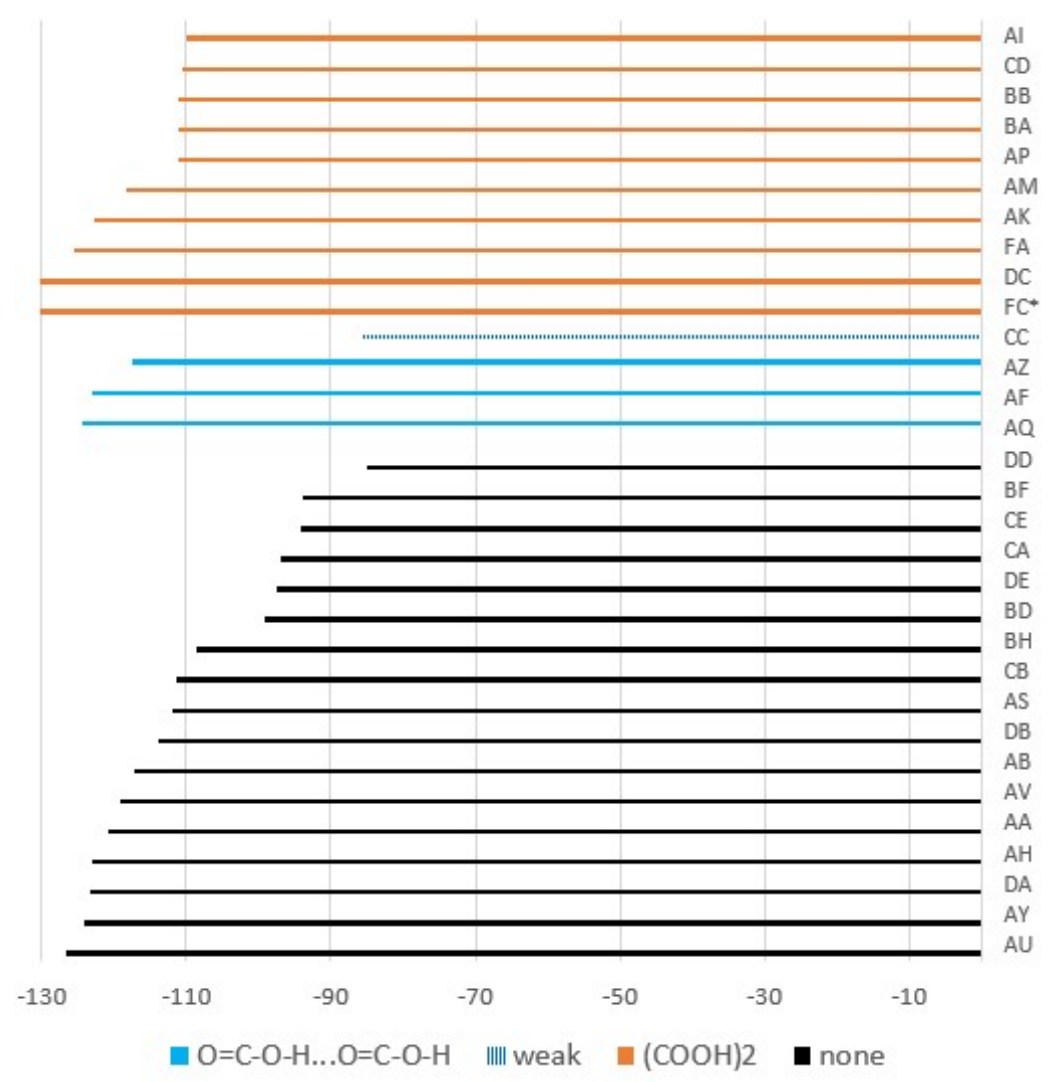

Figure S3. Analysis of $U_{\text {lattice }}$ with respect to the presence of $(\mathrm{COOH})_{2}$ synthons (orange color) or of $\mathrm{O}=\mathrm{C}-\mathrm{O}-\mathrm{H} . . . \mathrm{O}=\mathrm{C}-\mathrm{O}-\mathrm{H}$ chains (in blue) and absence (in black). The $U_{\text {lattice }}$ data are the same as those in Table 1. 


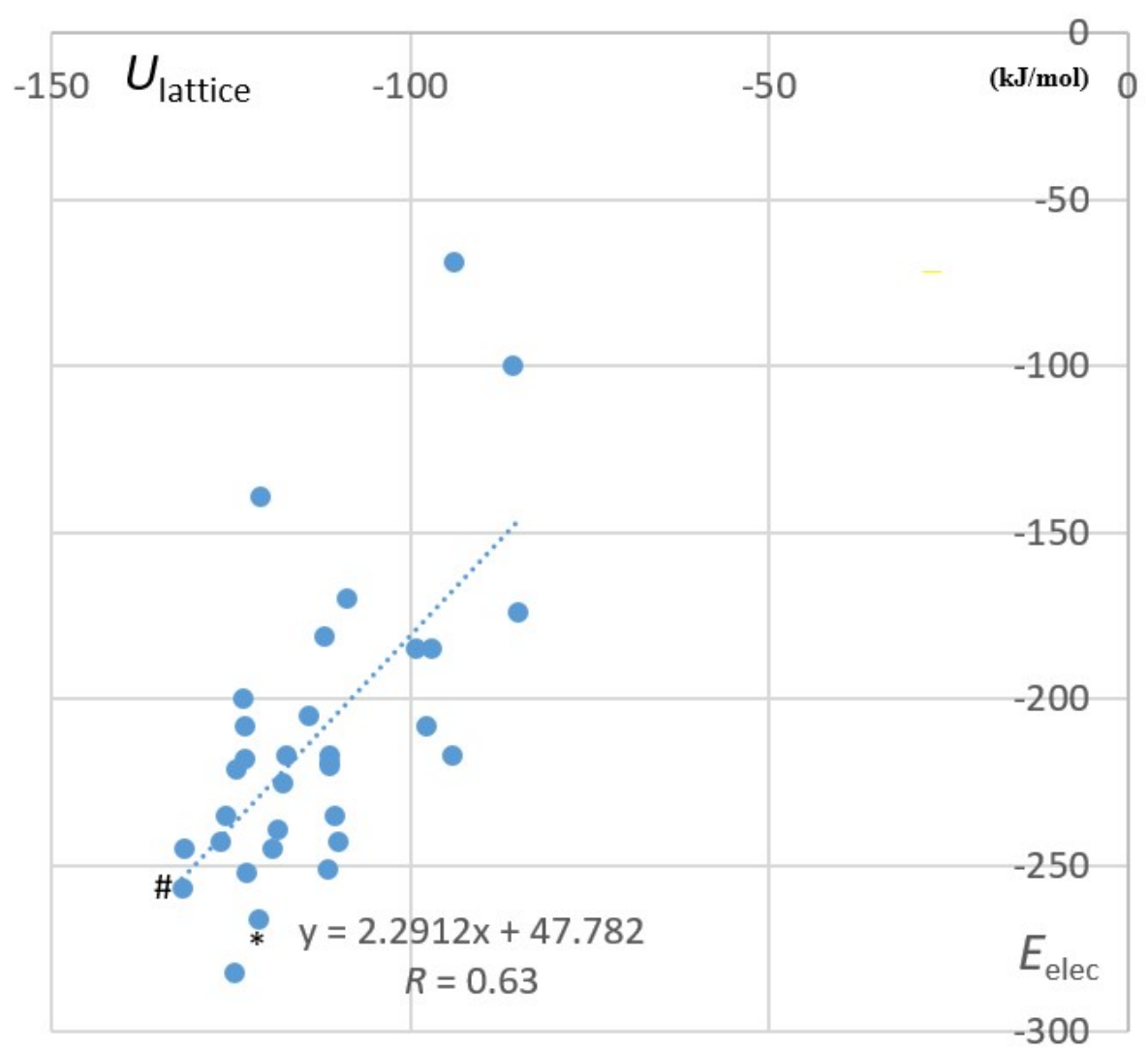

Figure S4. Scatterplot of lattice energy (Table 1) and electrostatic energy (Table 9) derived from transferred multipolar atom model. \#: predicted close to real FC, structure. *: real crystal structure.

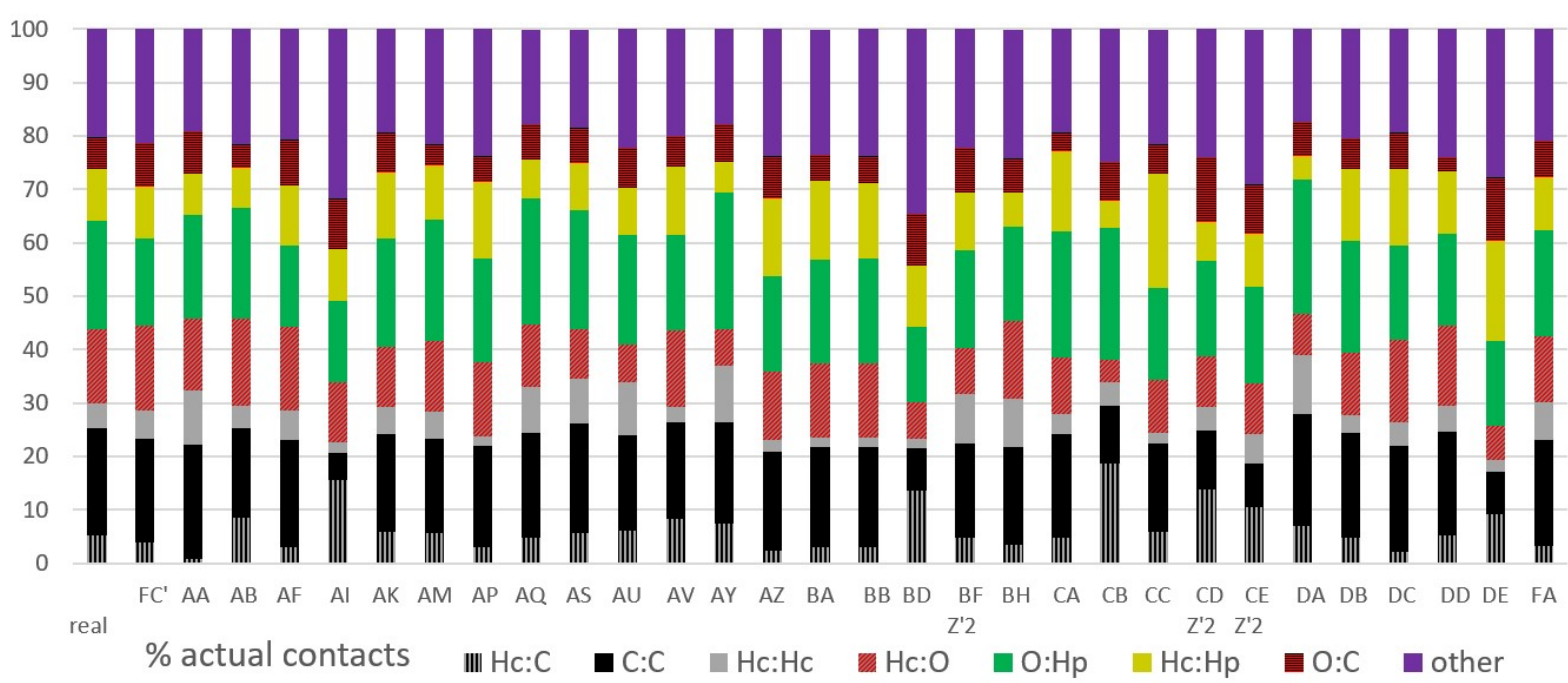

Figure S5. Percentage of actual contacts in the real and predicted crystal packings. 
Table S2. Coordinates of the predicted crystal structures.

Predicted Crystal Structures of the AMSA molecule, in SHELX format.

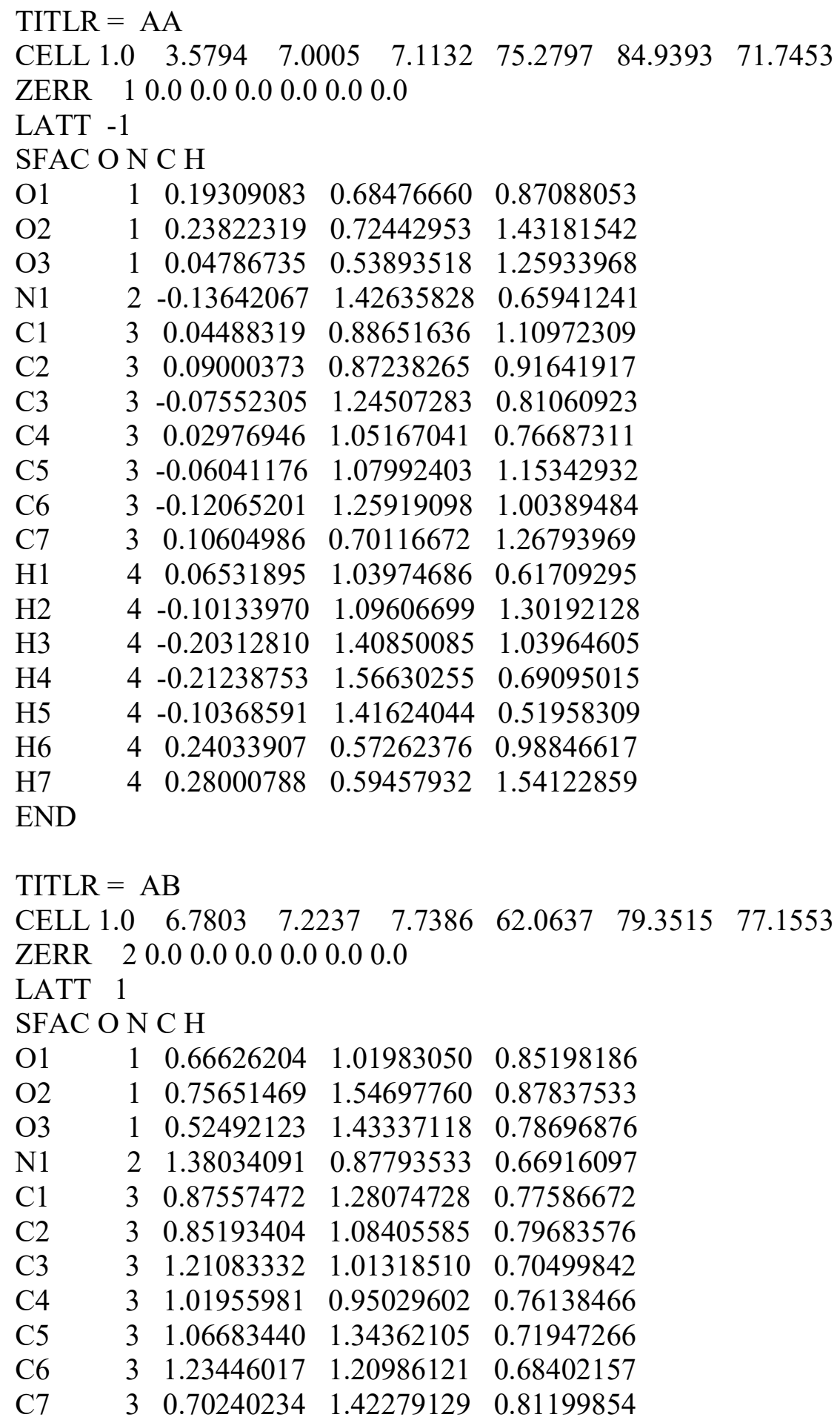




$\begin{array}{lllll}\text { H1 } & 4 & 1.00030615 & 0.79776856 & 0.77794873 \\ \text { H2 } & 4 & 1.08969701 & 1.49612427 & 0.70013212 \\ \text { H3 } & 4 & 1.38211201 & 1.26062715 & 0.63991580 \\ \text { H4 } & 4 & 1.51875791 & 0.92328416 & 0.62846541 \\ \text { H5 } & 4 & 1.36337347 & 0.73562572 & 0.68436955 \\ \text { H6 } & 4 & 0.56449871 & 1.12424964 & 0.87911535 \\ \text { H7 } & 4 & 0.63494985 & 1.64537972 & 0.90315501 \\ \text { END } & & & & \end{array}$

TITLR $=\mathrm{AF}$

$\begin{array}{lllllll}\text { CELL 1.0 } & 6.9631 & 3.6011 & 16.5399 & 90.0000 & 129.6038 & 90.0000\end{array}$ ZERR 20.00 .00 .00 .00 .00 .0

LATT -1

SYMM -X, $+\mathrm{Y}+1 / 2,-\mathrm{Z}$

SFAC O N C H

$\begin{array}{llllll}\text { O1 } & 1 & 0.61112150 & -0.12494153 & 0.83454052\end{array}$

$\begin{array}{llllll}\mathrm{O} 2 & & 1 & 0.25368911 & 0.01383482 & 0.52228612\end{array}$

$\begin{array}{llllll}\text { O3 } & 1 & 0.24593157 & -0.35913065 & 0.63104913\end{array}$

$\begin{array}{lllll}\mathrm{N} 1 & 2 & 1.38608782 & 0.20714427 & 0.91572316\end{array}$

$\begin{array}{llllll}\mathrm{C} 1 & 3 & 0.62601140 & -0.06084762 & 0.69426686\end{array}$

$\begin{array}{llllll}\mathrm{C} 2 & & 3 & 0.74173389 & -0.04984454 & 0.80082499\end{array}$

$\begin{array}{llllll}\mathrm{C} 3 & 3 & 1.13086952 & 0.11714889 & 0.84137062\end{array}$

$\begin{array}{llllll}\mathrm{C} 4 & 3 & 0.99417099 & 0.03913363 & 0.87437298\end{array}$

$\begin{array}{llllll}\text { C5 } & 3 & 0.76274030 & 0.01715933 & 0.66127694\end{array}$

$\begin{array}{llllll}\mathrm{C} 6 & 3 & 1.01514611 & 0.10612521 & 0.73481787\end{array}$

$\begin{array}{llllll}\mathrm{C} 7 & 3 & 0.36271449 & -0.15354509 & 0.61625872\end{array}$

$\begin{array}{lllll}\mathrm{H} 1 & 4 & 1.08296163 & 0.04733238 & 0.95697854\end{array}$

$\begin{array}{lllll}\mathrm{H} 2 & 4 & 0.67880279 & 0.00740761 & 0.57923940\end{array}$

$\begin{array}{lllll}\mathrm{H} 3 & 4 & 1.11947437 & 0.16540204 & 0.70826626\end{array}$

$\begin{array}{lllll}\mathrm{H} 4 & 4 & 1.48506431 & 0.26380017 & 0.89189989\end{array}$

$\begin{array}{lllll}\text { H5 } & 4 & 1.46987866 & 0.21529193 & 0.99279632\end{array}$

$\begin{array}{lllll}\mathrm{H} 6 & 4 & 0.43566448 & -0.16874493 & 0.77511413\end{array}$

$\begin{array}{lllll}\text { H7 } & 4 & 0.07032962 & -0.05228617 & 0.46844235\end{array}$

END

TITLR $=\mathrm{AH}$

$\begin{array}{lllllll}\text { CELL 1.0 } & 3.5734 & 11.0139 & 8.5886 & 90.0000 & 78.2309 & 90.0000\end{array}$

ZERR 20.00 .00 .00 .00 .00 .0

LATT -1

SYMM -X $,+Y+1 / 2,-Z$

SFAC O N C H

$\begin{array}{llllll}\text { O1 } & 1 & 1.16310898 & 0.22792466 & 0.27138876\end{array}$

$\begin{array}{llllll}\mathrm{O} 2 & & 1 & 0.89627719 & -0.06372155 & 0.56805853\end{array}$

$\begin{array}{llllll}\text { O3 } & & 1 & 1.21915154 & 0.11515476 & 0.55212373\end{array}$

N1 $\quad 2 \quad 1.30114434 \quad-0.03932086 \quad-0.17933014$

$\begin{array}{llllll}\mathrm{C} 1 & 3 & 1.15020201 & 0.01260311 & 0.31404759\end{array}$ 


$\begin{array}{lllll}\text { C2 } & 3 & 1.18132566 & 0.11265527 & 0.21259282 \\ \text { C3 } & 3 & 1.25044992 & -0.02187499 & -0.01365684 \\ \text { C4 } & 3 & 1.23147229 & 0.09540823 & 0.04874324 \\ \text { C5 } & 3 & 1.16919835 & -0.10467058 & 0.25163725 \\ \text { C6 } & 3 & 1.21934498 & -0.12191762 & 0.08778768 \\ \text { C7 } & 3 & 1.09813858 & 0.02869607 & 0.48545571 \\ \text { H1 } & 4 & 1.25534151 & 0.17341757 & -0.02942946 \\ \text { H2 } & 4 & 1.14965574 & -0.18412494 & 0.32715606 \\ \text { H3 } & 4 & 1.23445885 & -0.21341007 & 0.04071578 \\ \text { H4 } & 4 & 1.31468802 & -0.12413853 & -0.22453338 \\ \text { H5 } & 4 & 1.32353148 & 0.03300408 & -0.25275899 \\ \text { H6 } & 4 & 1.11325243 & 0.22698372 & 0.38742251 \\ \text { H7 } & 4 & 0.86140295 & -0.05174405 & 0.68733084 \\ \text { END } & & & & \end{array}$

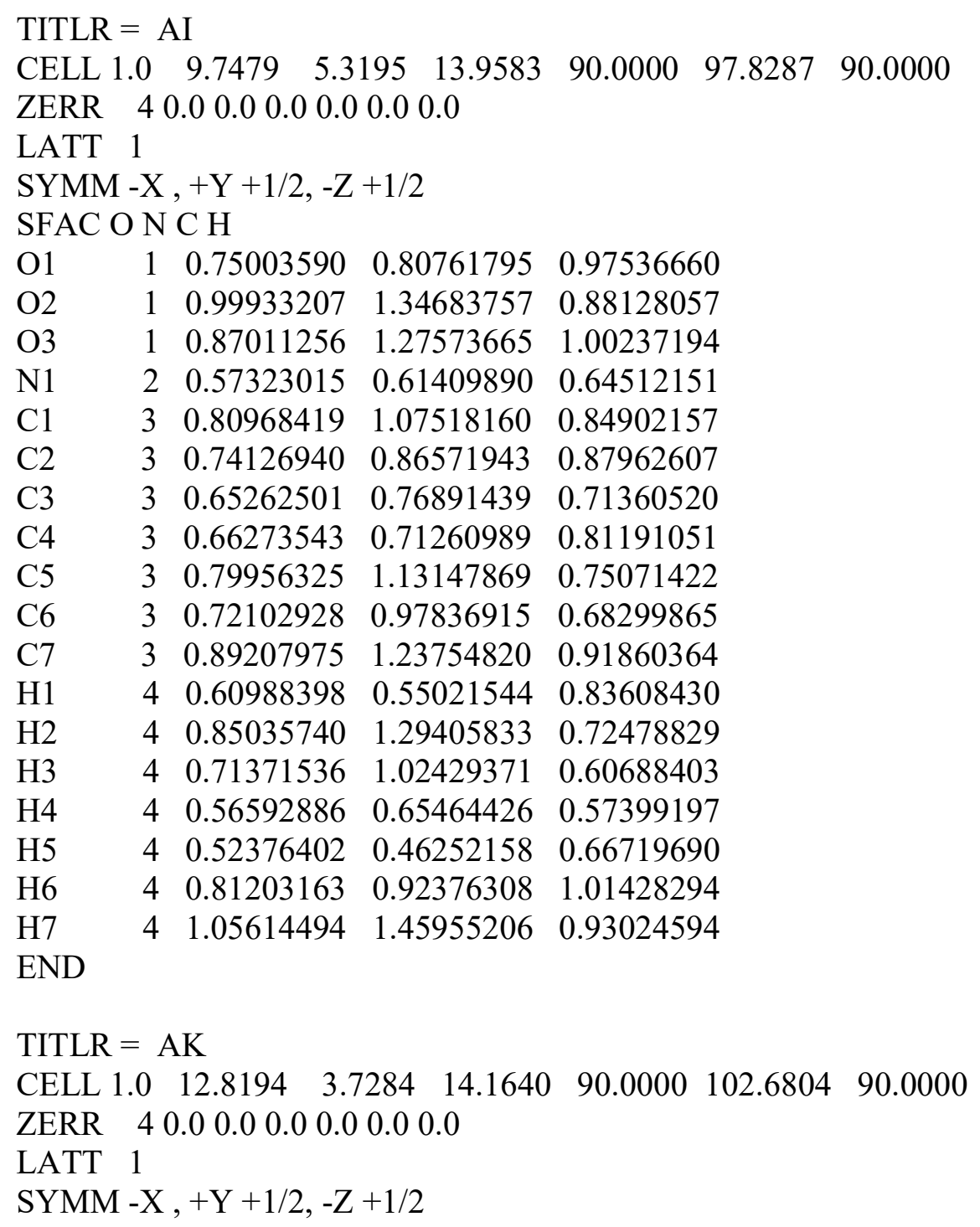




\begin{tabular}{lllll}
\multicolumn{5}{l}{ SFAC O N C H } \\
O1 & 1 & 0.82703265 & 1.13322204 & 0.58473149 \\
O2 & 1 & 0.51588044 & 1.19676422 & 0.61020336 \\
O3 & 1 & 0.63377676 & 1.48694006 & 0.53834017 \\
N1 & 2 & 0.92924499 & 0.74515634 & 0.91590571 \\
C1 & 3 & 0.69775372 & 1.15437991 & 0.68400007 \\
C2 & 3 & 0.80040569 & 1.07752373 & 0.67159330 \\
C3 & 3 & 0.85151677 & 0.88254986 & 0.83803964 \\
C4 & 3 & 0.87728695 & 0.94164019 & 0.74861473 \\
C5 & 3 & 0.67199028 & 1.09531024 & 0.77341260 \\
C6 & 3 & 0.74887153 & 0.95942671 & 0.85043402 \\
C7 & 3 & 0.61638049 & 1.29678057 & 0.60450149 \\
H1 & 4 & 0.95683733 & 0.88240338 & 0.73855012 \\
H2 & 4 & 0.59333511 & 1.15551502 & 0.78556409 \\
H3 & 4 & 0.72797582 & 0.91539997 & 0.91957409 \\
H4 & 4 & 0.91064227 & 0.70218100 & 0.98059799 \\
H5 & 4 & 1.00349324 & 0.68937825 & 0.90697307 \\
H6 & 4 & 0.76512797 & 1.21542717 & 0.53648707 \\
H7 & 4 & 0.45974672 & 1.29713592 & 0.55454913 \\
END & & & &
\end{tabular}

TITLR $=$ AM

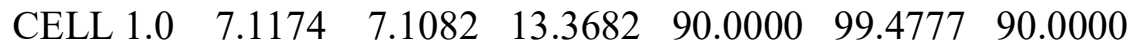
ZERR 40.00 .00 .00 .00 .00 .0

LATT 1

SYMM -X $,+Y+1 / 2,-Z+1 / 2$

SFAC O N C H

$\begin{array}{llllll}\text { O1 } & 1 & 0.94611578 & 0.11716341 & 0.40385583\end{array}$

$\begin{array}{lllll}\mathrm{O} 2 & 1 & 1.48369727 & -0.00787801 & 0.35360414\end{array}$

$\begin{array}{llllll}\text { O3 } & 1 & 1.33365720 & 0.15146809 & 0.46504190\end{array}$

$\begin{array}{lllll}\mathrm{N} 1 & 2 & 0.74014742 & 0.17426959 & 0.04414042\end{array}$

$\begin{array}{llllll}\mathrm{C} 1 & 3 & 1.17952440 & 0.11158221 & 0.29332845\end{array}$

$\begin{array}{llllll}\mathrm{C} 2 & 3 & 0.99074278 & 0.12462780 & 0.30861815\end{array}$

$\begin{array}{llllll}\mathrm{C} 3 & & 3 & 0.88767926 & 0.15321676 & 0.12782333\end{array}$

$\begin{array}{llllll}\mathrm{C} 4 & 3 & 0.84482692 & 0.14546695 & 0.22586048\end{array}$

$\begin{array}{lllllll}\text { C5 } & & 3 & 1.22235781 & 0.11934244 & 0.19528054\end{array}$

$\begin{array}{llllll}\text { C6 } & 3 & 1.07645090 & 0.14017180 & 0.11253364\end{array}$

$\begin{array}{llllll}\text { C7 } & 3 & 1.33393211 & 0.08997847 & 0.37874421\end{array}$

$\begin{array}{llllll}\mathrm{H} 1 & 4 & 0.69853874 & 0.15546784 & 0.23819841\end{array}$

$\begin{array}{lllll}\mathrm{H} 2 & 4 & 1.36759963 & 0.11141739 & 0.18103572\end{array}$

$\begin{array}{lllll}\mathrm{H} 3 & 4 & 1.11152724 & 0.14640750 & 0.03678740\end{array}$

$\begin{array}{llllll}\mathrm{H} 4 & 4 & 0.77104177 & 0.17979487 & -0.02680567\end{array}$

$\begin{array}{llllll}\mathrm{H} 5 & 4 & 0.60356892 & 0.18365346 & 0.05513899\end{array}$

$\begin{array}{llllll}\mathrm{H} 6 & 4 & 1.06002361 & 0.09531177 & 0.45405541\end{array}$

$\begin{array}{lllll}\text { H7 } & 4 & 1.59053985 & -0.02223716 & 0.41355192\end{array}$

END 


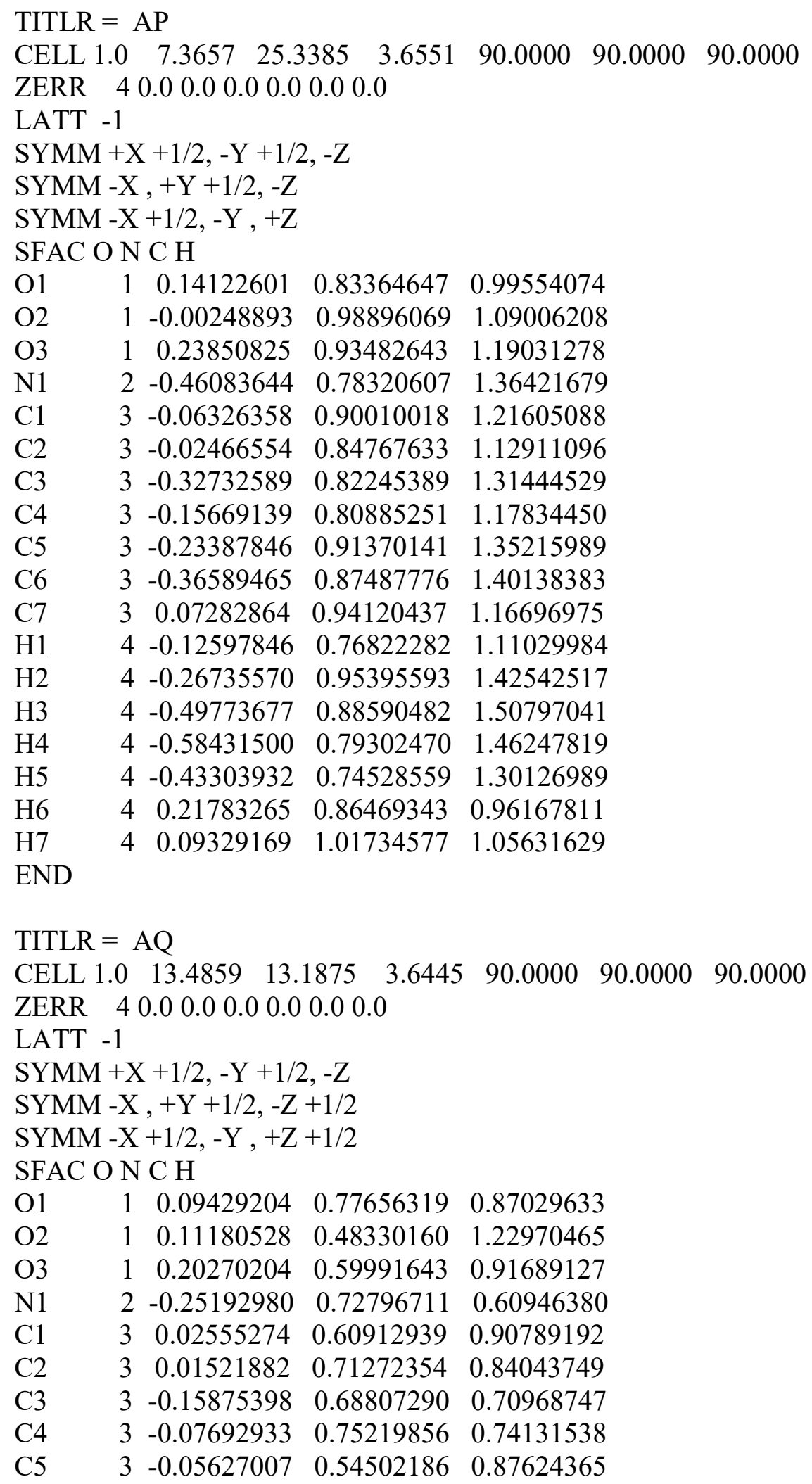




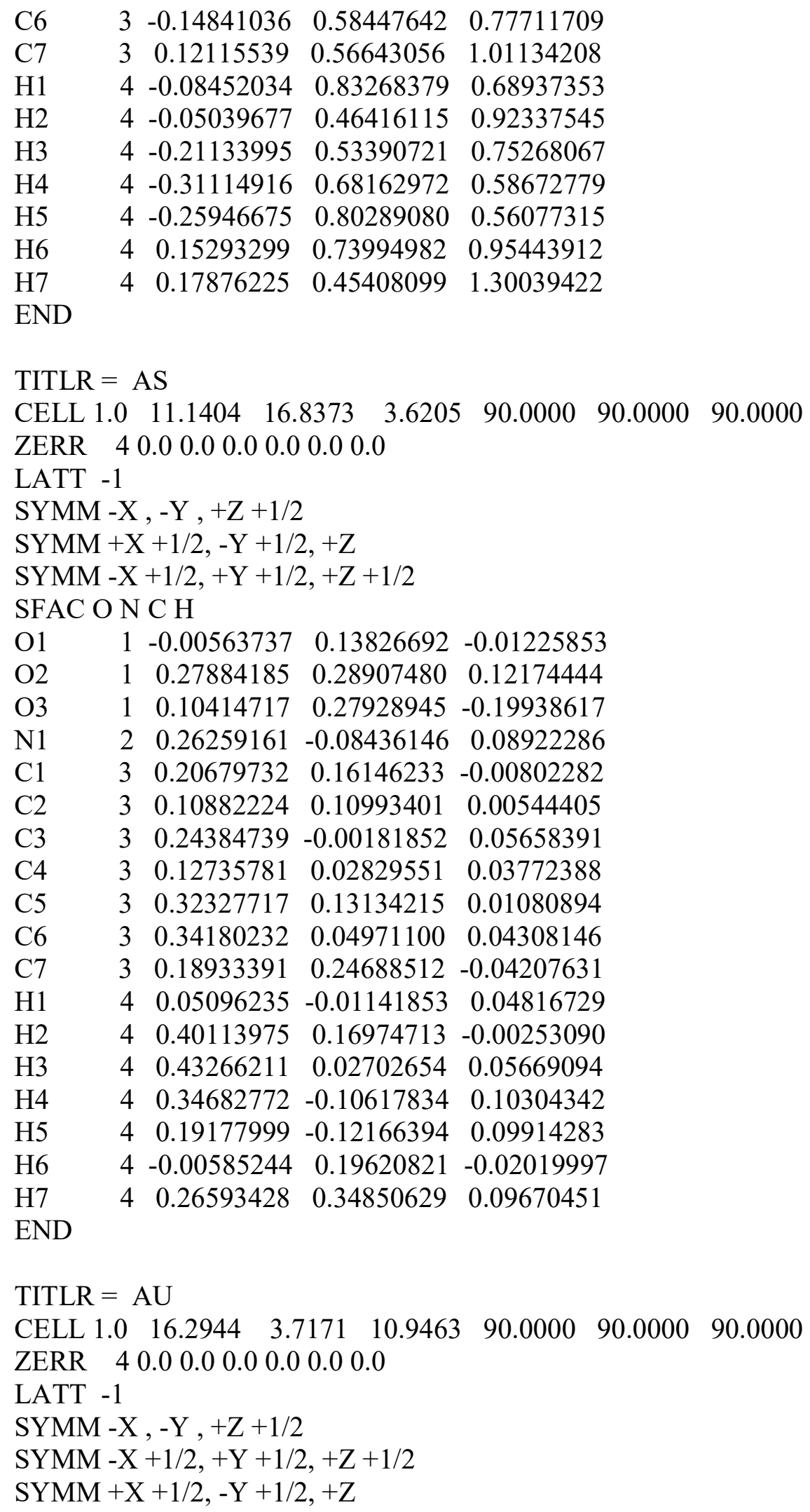




\begin{tabular}{|c|c|c|c|c|}
\hline \multicolumn{5}{|c|}{ SFAC O N C H } \\
\hline $\mathrm{O} 1$ & 1 & 0.89596552 & 0.79046265 & 0.78641483 \\
\hline $\mathrm{O} 2$ & 1 & 1.05205373 & 0.78744563 & 1.07902152 \\
\hline $\mathrm{O} 3$ & 1 & 1.02503586 & 0.46781872 & 0.90660707 \\
\hline N1 & 2 & 0.67770436 & 1.19213943 & 1.04860732 \\
\hline $\mathrm{C} 1$ & 3 & 0.91776911 & 0.80305993 & 1.00309264 \\
\hline $\mathrm{C} 2$ & 3 & 0.86786009 & 0.85962924 & 0.90131610 \\
\hline $\mathrm{C} 3$ & 3 & 0.75831191 & 1.06149964 & 1.03331213 \\
\hline $\mathrm{C} 4$ & 3 & 0.78813342 & 0.98882527 & 0.91644230 \\
\hline $\mathrm{C} 5$ & 3 & 0.88794074 & 0.87572790 & 1.11995295 \\
\hline C6 & 3 & 0.80821699 & 1.00490627 & 1.13506699 \\
\hline $\mathrm{C} 7$ & 3 & 1.00116342 & 0.66795819 & 0.98922985 \\
\hline H1 & 4 & 0.74968327 & 1.03232748 & 0.83710436 \\
\hline $\mathrm{H} 2$ & 4 & 0.92490771 & 0.83130408 & 1.20078007 \\
\hline $\mathrm{H} 3$ & 4 & 0.78568737 & 1.05960778 & 1.22627510 \\
\hline $\mathrm{H} 4$ & 4 & 0.65611393 & 1.24494733 & 1.13311895 \\
\hline H5 & 4 & 0.64158281 & 1.23324751 & 0.97505019 \\
\hline H6 & 4 & 0.95331832 & 0.71500600 & 0.78858391 \\
\hline H7 & 4 & 1.11000070 & 0.69203946 & 1.06863458 \\
\hline \multicolumn{5}{|c|}{ - } \\
\hline \multicolumn{5}{|c|}{$\mathrm{TITLR}=\mathrm{AV}$} \\
\hline \multicolumn{5}{|c|}{ CELL $1.0 \quad 15.2332$} \\
\hline \multicolumn{5}{|c|}{ ZERR $\quad 4 \quad 0.00 .00 .00 .00 .00 .0$} \\
\hline \multicolumn{5}{|c|}{ LATT -1} \\
\hline \multicolumn{5}{|c|}{ SYMM -X , -Y , +Z +1/2 } \\
\hline \multicolumn{5}{|c|}{ SYMM -X +1/2, +Y +1/2, +Z +1/2 } \\
\hline \multicolumn{5}{|c|}{$\mathrm{SYMM}+\mathrm{X}+1 / 2,-\mathrm{Y}+1 / 2,+\mathrm{Z}$} \\
\hline \multicolumn{5}{|c|}{ SFAC O N C H } \\
\hline $\mathrm{O} 1$ & 1 & 0.75261270 & 0.73826444 & 0.80720978 \\
\hline $\mathrm{O} 2$ & 1 & 0.65513190 & 1.03884835 & 1.09842021 \\
\hline $\mathrm{O} 3$ & 1 & 0.77758162 & 0.93413521 & 1.16772590 \\
\hline N1 & 2 & 0.46475411 & 0.58205808 & 0.94943068 \\
\hline $\mathrm{C} 1$ & 3 & 0.63844140 & 0.84765129 & 1.07227937 \\
\hline $\mathrm{C} 2$ & 3 & 0.66781919 & 0.74948862 & 0.91897282 \\
\hline $\mathrm{C} 3$ & 3 & 0.52308703 & 0.67124655 & 0.99065213 \\
\hline $\mathrm{C} 4$ & 3 & 0.61013880 & 0.66128410 & 0.87819571 \\
\hline $\mathrm{C} 5$ & 3 & 0.55138661 & 0.85759051 & 1.18475993 \\
\hline C6 & 3 & 0.49372567 & 0.76939578 & 1.14396468 \\
\hline $\mathrm{C} 7$ & 3 & 0.69766048 & 0.94065697 & 1.11755594 \\
\hline $\mathrm{H} 1$ & 4 & 0.63329563 & 0.58529035 & 0.75891144 \\
\hline $\mathrm{H} 2$ & 4 & 0.52684789 & 0.93233426 & 1.30784944 \\
\hline $\mathrm{H} 3$ & 4 & 0.42634028 & 0.77803419 & 1.23300937 \\
\hline H4 & 4 & 0.40176412 & 0.58922825 & 1.03054956 \\
\hline H5 & 4 & 0.48594137 & 0.51105182 & 0.83844837 \\
\hline H6 & 4 & 0.78474266 & 0.80703220 & 0.83856818 \\
\hline
\end{tabular}


$\mathrm{H} 7$ $4 \quad 0.69689556 \quad 1.10315046 \quad 1.13021072$

END

TITLR $=$ AY

$\begin{array}{lllllll}\text { CELL 1.0 } & 16.5870 & 3.6285 & 11.0156 & 90.0000 & 90.0000 & 90.0000\end{array}$

ZERR 40.00 .00 .00 .00 .00 .0

LATT -1

SYMM -X, $-\mathrm{Y},+\mathrm{Z}+1 / 2$

SYMM $-X+1 / 2,+Y,+Z+1 / 2$

$\mathrm{SYMM}+\mathrm{X}+1 / 2,-\mathrm{Y},+\mathrm{Z}$

SFAC O N C H

$\begin{array}{lllll}\mathrm{O} 1 & 1 & 0.63310783 & 0.90504103 & 0.23044699\end{array}$

$\begin{array}{llllll}\mathrm{O} 2 & 1 & 0.78660837 & 0.86234786 & -0.05978744\end{array}$

$\begin{array}{llllll}\mathrm{O} 3 & 1 & 0.76779745 & 1.18089515 & 0.11562018\end{array}$

N1 $\quad 2 \quad \begin{array}{lllll}2 & 0.41079930 & 0.63987616 & -0.03562393\end{array}$

$\begin{array}{llllll}\mathrm{C} 1 & 3 & 0.65487843 & 0.90659719 & 0.01517333\end{array}$

$\begin{array}{llllll}\mathrm{C} 2 & & 3 & 0.60433936 & 0.86272043 & 0.11538469\end{array}$

$\begin{array}{llllll}\mathrm{C} 3 & & 3 & 0.49274542 & 0.72943591 & -0.01854456\end{array}$

$\begin{array}{llllll}\mathrm{C} 4 & 3 & 0.52328414 & 0.77416797 & 0.09850936\end{array}$

$\begin{array}{llllll}\text { C5 } & 3 & 0.62434906 & 0.86187677 & -0.10188614\end{array}$

$\begin{array}{llllll}\mathrm{C} 6 & 3 & 0.54327702 & 0.77331087 & -0.11874089\end{array}$

$\begin{array}{llllll}\text { C7 } & 3 & 0.73967260 & 0.99944713 & 0.03087189\end{array}$

$\begin{array}{llllll}\mathrm{H} 1 & 4 & 0.48435140 & 0.74036738 & 0.17664498\end{array}$

$\begin{array}{llllll}\mathrm{H} 2 & 4 & 0.66185826 & 0.89756423 & -0.18149568\end{array}$

$\begin{array}{llllll}\mathrm{H} 3 & 4 & 0.52023217 & 0.74003968 & -0.21007370\end{array}$

H4 $\quad 4 \quad 0.38867816 \quad 0.60727389 \quad-0.12027184$

$\begin{array}{lllll}\text { H5 } & 4 & 0.37421752 & 0.60795239 & 0.03680049\end{array}$

$\begin{array}{llllll}\text { H6 } & 4 & 0.69102179 & 0.95250017 & 0.22939439\end{array}$

$\begin{array}{llllll}\mathrm{H} 7 & 4 & 0.84556591 & 0.92832889 & -0.04810397\end{array}$

END

TITL starting1 starting1 starting1 $\mathrm{R}=0.0 \mathrm{AZ}$

$\begin{array}{lllllll}\text { CELL 1.0 } & 25.3055 & 3.6439 & 6.9892 & 90.0000 & 90.0000 & 90.0000\end{array}$

ZERR 40.00 .00 .00 .00 .00 .0

LATT -1

$\mathrm{SYMM}+\mathrm{X}+1 / 2,-\mathrm{Y}+1 / 2,-\mathrm{Z}$

SYMM -X, $+\mathrm{Y}+1 / 2,-\mathrm{Z}+1 / 2$

SYMM $-X+1 / 2,-Y,+Z+1 / 2$

SFAC O N C H

$\begin{array}{llllll}\text { O1 } & 1 & 0.83145037 & 0.97991598 & 0.35687384\end{array}$

$\begin{array}{llllll}\mathrm{O} 2 & 1 & 0.98823509 & 1.15159185 & 0.46726591\end{array}$

$\begin{array}{llllll}\text { O3 } & 1 & 0.93472306 & 0.76570728 & 0.30067045\end{array}$

N1 $\quad 2 \quad 0.79014657 \quad 1.32718362 \quad 1.00343760$

$\begin{array}{lllll}\mathrm{C} 1 & 3 & 0.90210375 & 1.06604008 & 0.58121087\end{array}$

$\begin{array}{lllll}\mathrm{C} 2 & 3 & 0.84836712 & 1.06484443 & 0.53665410\end{array}$

$\begin{array}{llllll}\mathrm{C} 3 & 3 & 0.82773563 & 1.23948948 & 0.86164330\end{array}$ 


$\begin{array}{lllll}\text { C4 } & 3 & 0.81118578 & 1.15154178 & 0.67688072 \\ \text { C5 } & 3 & 0.91866110 & 1.15400744 & 0.76596192 \\ \text { C6 } & 3 & 0.88147306 & 1.24067237 & 0.90617699 \\ \text { C7 } & 3 & 0.94154506 & 0.97592204 & 0.43685949 \\ \text { H1 } & 4 & 0.76952267 & 1.15026899 & 0.64145471 \\ \text { H2 } & 4 & 0.96004727 & 1.15385348 & 0.80541998 \\ \text { H3 } & 4 & 0.89479747 & 1.30774481 & 1.04921632 \\ \text { H4 } & 4 & 0.80209033 & 1.39099660 & 1.13709550 \\ \text { H5 } & 4 & 0.75127461 & 1.32650727 & 0.97129803 \\ \text { H6 } & 4 & 0.86142560 & 0.93881973 & 0.27165308 \\ \text { H7 } & 4 & 1.01546155 & 1.08720771 & 0.36604507 \\ \text { END } & & & & \end{array}$

TITLR $=$ BA

$\begin{array}{lllllll}\text { CELL 1.0 } & 25.3436 & 7.3548 & 3.6582 & 90.0000 & 90.0000 & 90.0000\end{array}$ ZERR 40.00 .00 .00 .00 .00 .0

LATT -1

$\mathrm{SYMM}+\mathrm{X}+1 / 2,-\mathrm{Y}+1 / 2,-\mathrm{Z}$

SYMM -X $,+\mathrm{Y}+1 / 2,-\mathrm{Z}$

SYMM $-X+1 / 2,-Y,+Z$

SFAC O N C H

$\begin{array}{lllll}\text { O1 } & 1 & 0.91638607 & 0.39124338 & 0.99318794\end{array}$

$\begin{array}{llllll}\mathrm{O} 2 & & 1 & 0.76109477 & 0.24721638 & 1.08696850\end{array}$

$\begin{array}{llllll}\text { O3 } & & 1 & 0.81517120 & 0.48875782 & 1.18643061\end{array}$

$\begin{array}{lllll}\text { N1 } & 2 & 0.96681000 & -0.21118968 & 1.36495098\end{array}$

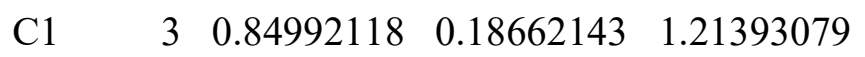

$\begin{array}{llllll}\mathrm{C} 2 & & 3 & 0.90234682 & 0.22525308 & 1.12735291\end{array}$

$\begin{array}{llllll}\mathrm{C} 3 & 3 & 0.92756593 & -0.07759322 & 1.31421398\end{array}$

$\begin{array}{llllll}\mathrm{C} 4 & & 3 & 0.94116455 & 0.09313151 & 1.17753185\end{array}$

$\begin{array}{llllll}\text { C5 } & 3 & 0.83632290 & 0.01590669 & 1.35063071\end{array}$

$\begin{array}{lllll}\text { C6 } & 3 & 0.87515094 & -0.11619548 & 1.40079025\end{array}$

$\begin{array}{llllll}\mathrm{C} 7 & 3 & 0.80882213 & 0.32279950 & 1.16386799\end{array}$

$\begin{array}{lllll}\mathrm{H} 1 & 4 & 0.98179443 & 0.12386661 & 1.10974537\end{array}$

$\begin{array}{lllll}\mathrm{H} 2 & 4 & 0.79606641 & -0.01758386 & 1.42363241\end{array}$

$\begin{array}{llllll}\mathrm{H} 3 & 4 & 0.86411934 & -0.24811527 & 1.50783458\end{array}$

H4 $\quad 4 \quad 0.95699235 \quad-0.33474978 \quad 1.46363323$

H5 $\quad 4 \quad 1.00473127 \quad-0.18337961 \quad 1.30225347$

$\begin{array}{lllll}\text { H6 } & 4 & 0.88533925 & 0.46786460 & 0.95872939\end{array}$

$\begin{array}{lllll}\mathrm{H} 7 & 4 & 0.73271012 & 0.34305528 & 1.05252061\end{array}$

END

TITLR $=$ BB

$\begin{array}{lllllll}\text { CELL 1.0 } & 25.3297 & 7.3654 & 3.6571 & 90.0000 & 90.0000 & 90.0000\end{array}$ ZERR 40.00 .00 .00 .00 .00 .0

LATT -1

$\mathrm{SYMM}+\mathrm{X}+1 / 2,-\mathrm{Y},-\mathrm{Z}$ 


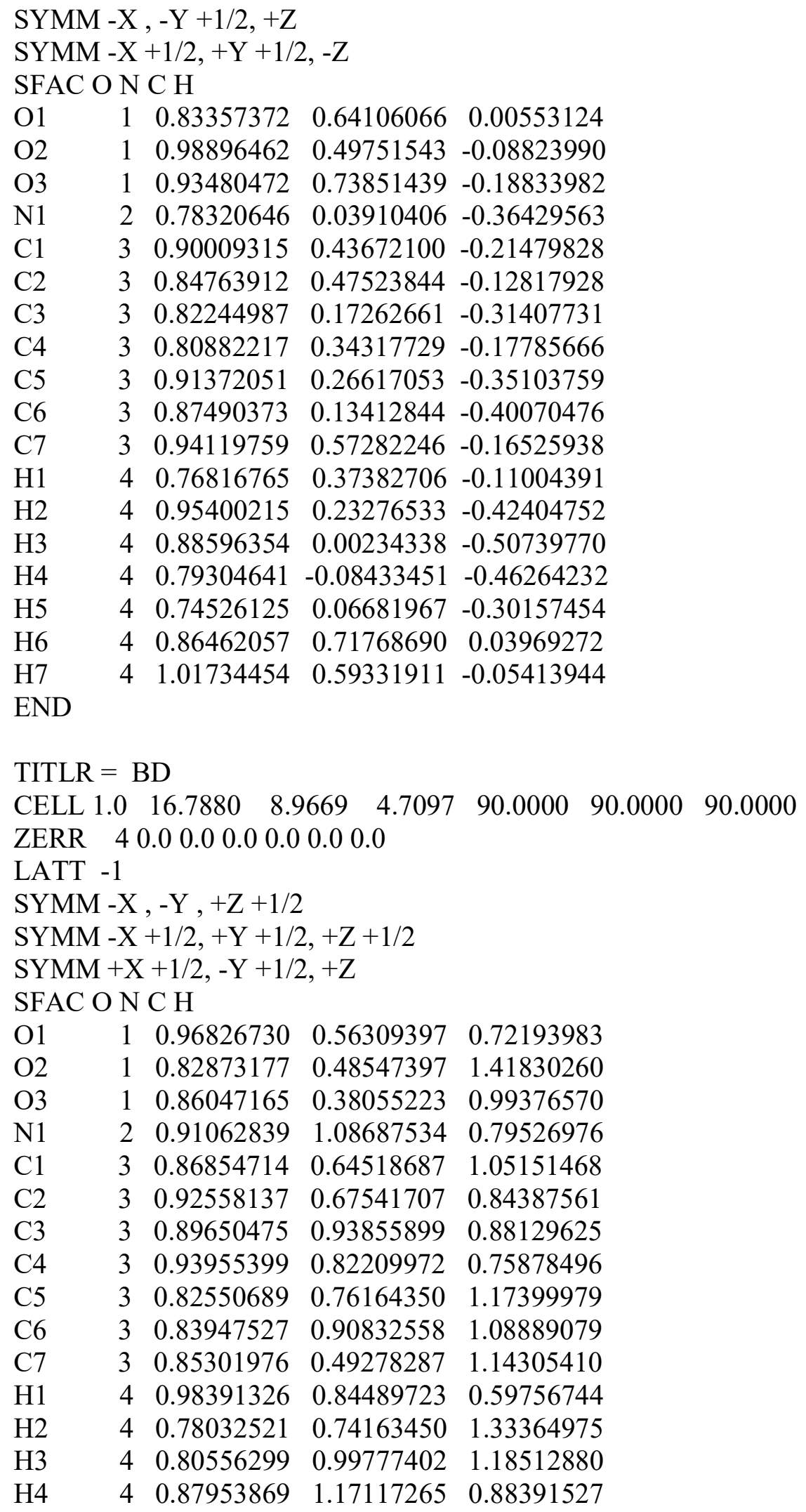




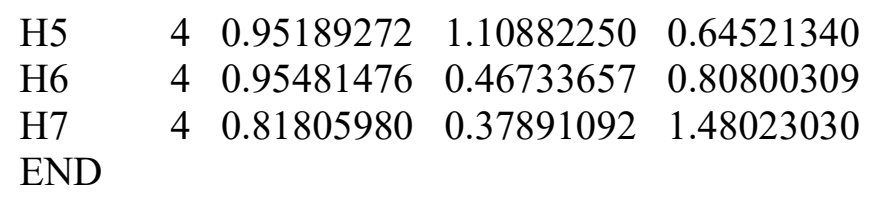




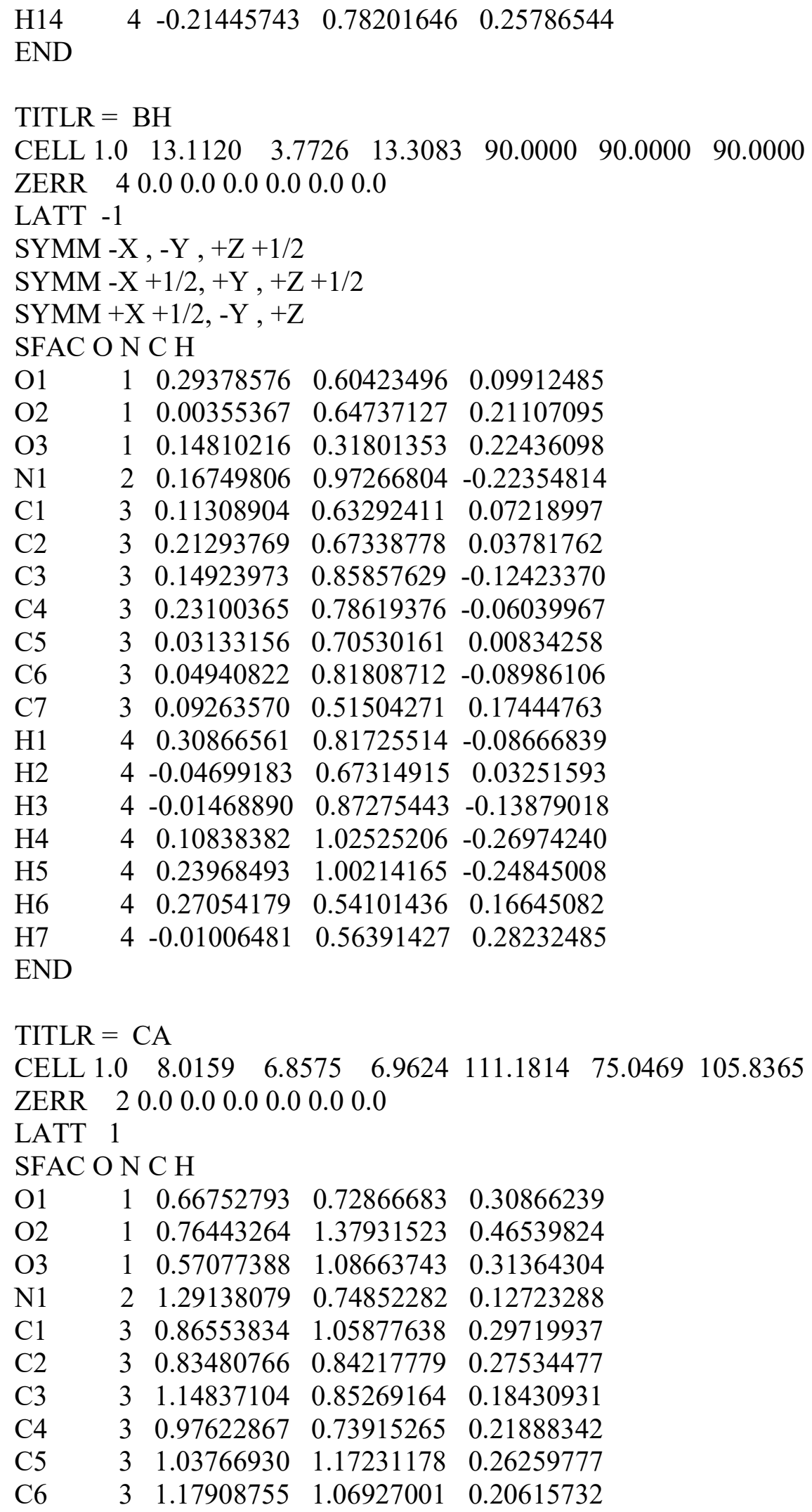




$\begin{array}{lllll}\mathrm{C} 7 & 3 & 0.71964268 & 1.16922482 & 0.35581980 \\ \mathrm{H} 1 & 4 & 0.95158698 & 0.57100406 & 0.20221331 \\ \mathrm{H} 2 & 4 & 1.06568474 & 1.34003325 & 0.27637784 \\ \mathrm{H} 3 & 4 & 1.31211997 & 1.15900226 & 0.17929182 \\ \mathrm{H} 4 & 4 & 1.41593084 & 0.83058491 & 0.10230636 \\ \mathrm{H} 5 & 4 & 1.26925557 & 0.59189228 & 0.11147382 \\ \mathrm{H} 6 & 4 & 0.58207670 & 0.82130349 & 0.35464814 \\ \mathrm{H} 7 & 4 & 0.66202127 & 1.45495215 & 0.50557580 \\ \text { END } & & & & \end{array}$

TITLR $=$ CB

$\begin{array}{lllllll}\text { CELL 1.0 } & 16.4670 & 11.9587 & 6.8246 & 90.0000 & 90.0000 & 90.0000\end{array}$ ZERR 80.00 .00 .00 .00 .00 .0

LATT 1

$\mathrm{SYMM}+\mathrm{X}+1 / 2,-\mathrm{Y}+1 / 2,-\mathrm{Z}$

SYMM $-X,+Y+1 / 2,-Z+1 / 2$

SYMM $-X+1 / 2,-Y,+Z+1 / 2$

SFAC O N C H

$\begin{array}{lllll}\mathrm{O} 1 & 1 & 0.04506577 & 0.23305134 & 0.10412488\end{array}$

$\begin{array}{lllll}\mathrm{O} 2 & 1 & 0.03555344 & -0.10339645 & 0.20915225\end{array}$

$\begin{array}{llllll}\text { O3 } & 1 & -0.02993333 & 0.05712262 & 0.29185019\end{array}$

N1 $\quad 2 \quad 0.33670582 \quad 0.21430406 \quad 0.10013830$

$\begin{array}{llllll}\mathrm{C} 1 & 3 & 0.11051417 & 0.06292486 & 0.20275595\end{array}$

$\begin{array}{llllll}\mathrm{C} 2 & 3 & 0.11420853 & 0.17317644 & 0.13651516\end{array}$

$\begin{array}{lllll}\mathrm{C} 3 & 3 & 0.26074912 & 0.16348243 & 0.13459289\end{array}$

$\begin{array}{lllll}\text { C4 } & 3 & 0.18933009 & 0.22345023 & 0.10245373\end{array}$

$\begin{array}{lllll}\text { C5 } & 3 & 0.18193342 & 0.00296775 & 0.23489425\end{array}$

$\begin{array}{lllll}\text { C6 } & 3 & 0.25705531 & 0.05324129 & 0.20082349\end{array}$

$\begin{array}{lllll}\text { C7 } & 3 & 0.03267559 & 0.00897162 & 0.23938732\end{array}$

$\begin{array}{llllll}\mathrm{H} 1 & 4 & 0.19182142 & 0.30904866 & 0.05098959\end{array}$

$\begin{array}{lllll}\mathrm{H} 2 & 4 & 0.18106703 & -0.08235424 & 0.28804877\end{array}$

$\begin{array}{lllll}\mathrm{H} 3 & 4 & 0.31209096 & 0.00591123 & 0.22670396\end{array}$

H4 $\quad \begin{array}{lllll}4 & 0.38839162 & 0.17095166 & 0.12326636\end{array}$

$\begin{array}{lllll}\text { H5 } & 4 & 0.33943209 & 0.29402521 & 0.05216959\end{array}$

$\begin{array}{llllll}\text { H6 } & 4 & -0.00290911 & 0.18684542 & 0.12641736\end{array}$

H7 $\quad 4 \quad-0.01891833 \quad-0.14027542 \quad 0.23500786$

END

TITLR $=$ CC

$\begin{array}{lllllll}\text { CELL 1.0 } & 7.5318 & 7.1228 & 27.2592 & 90.0000 & 90.0000 & 90.0000\end{array}$

ZERR $\quad 80.00 .00 .00 .00 .00 .0$

LATT 1

$\mathrm{SYMM}+\mathrm{X}+1 / 2,-\mathrm{Y}+1 / 2,-\mathrm{Z}$

SYMM -X , $+Y+1 / 2,-Z+1 / 2$

SYMM -X $+1 / 2,-Y,+Z+1 / 2$

SFAC O N C H 


$\begin{array}{lrrrr}\text { O1 } & 1 & 0.15100495 & 0.66245564 & 0.11186963 \\ \text { O2 } & 1 & -0.17960948 & 0.87729007 & 0.21682743 \\ \text { O3 } & 1 & 0.05988342 & 0.68505353 & 0.20959308 \\ \text { N1 } & 2 & -0.34500218 & 0.60899941 & 0.00173553 \\ \text { C1 } & 3 & -0.14301831 & 0.71665801 & 0.14257093 \\ \text { C2 } & 3 & -0.02764226 & 0.67183223 & 0.10428428 \\ \text { C3 } & 3 & -0.27716405 & 0.64515610 & 0.04902290 \\ \text { C4 } & 3 & -0.09473412 & 0.63608777 & 0.05751301 \\ \text { C5 } & 3 & -0.32543988 & 0.72572859 & 0.13408072 \\ \text { C6 } & 3 & -0.39252112 & 0.68997539 & 0.08730680 \\ \text { C7 } & 3 & -0.07561976 & 0.75427163 & 0.19168379 \\ \text { H1 } & 4 & -0.00455188 & 0.60141741 & 0.02792418 \\ \text { H2 } & 4 & -0.41848709 & 0.75839153 & 0.16314361 \\ \text { H3 } & 4 & -0.53444426 & 0.69705627 & 0.08119772 \\ \text { H4 } & 4 & -0.47694224 & 0.61564718 & -0.00443778 \\ \text { H5 } & 4 & -0.26165036 & 0.57665243 & -0.02598237 \\ \text { H6 } & 4 & 0.18031724 & 0.69733017 & 0.14553452 \\ \text { H7 } & 4 & -0.13163559 & 0.90264909 & 0.25098660 \\ \text { END } & & & & \end{array}$

TITL CD

$\begin{array}{lllllll}\text { CELL 1.0 } & 13.5447 & 6.7812 & 14.6768 & 90.0000 & 90.0000 & 88.6515\end{array}$ ZERR $\quad 80.00 .00 .00 .00 .00 .0$

LATT -1

$\mathrm{SYMM}+\mathrm{X}+1 / 2,+\mathrm{Y}+1 / 2,-\mathrm{Z}+1 / 2$

SFAC O N C H

$\begin{array}{lllll}\text { O1 } & 1 & 0.24759138 & 0.91101339 & 0.04320459\end{array}$

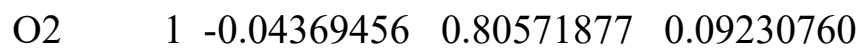

$\begin{array}{llllll}\mathrm{O} 3 & & 1 & 0.10716707 & 0.75949729 & 0.15778102\end{array}$

$\begin{array}{lllll}\text { O4 } & 1 & 0.75963471 & 0.61315036 & 0.88250302\end{array}$

$\begin{array}{llllll}\text { O5 } & 1 & 0.46453004 & 0.68486038 & 0.82946291\end{array}$

$\begin{array}{lllll}\text { O6 } & 1 & 0.61344463 & 0.76475052 & 0.77031263\end{array}$

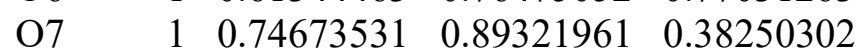

$\begin{array}{lllll}\text { O8 } & 1 & 1.04183999 & 0.82150960 & 0.32946291\end{array}$

$\begin{array}{lllll}\text { O9 } & 1 & 0.89292540 & 0.74161945 & 0.27031264\end{array}$

$\begin{array}{llllll}\mathrm{O} 10 & 1 & 0.25877864 & 0.59535658 & 0.54320459\end{array}$

$\begin{array}{llllll}\mathrm{O} 11 & 1 & 0.55006459 & 0.70065120 & 0.59230760\end{array}$

$\begin{array}{llllll}\mathrm{O} 12 & 1 & 0.39920296 & 0.74687268 & 0.65778102\end{array}$

$\begin{array}{llllll}\mathrm{N} 1 & 2 & 0.19685341 & 0.77113759 & -0.27426958\end{array}$

$\begin{array}{lllll}\mathrm{N} 2 & 2 & 0.69299331 & 0.68490204 & 1.20268423\end{array}$

$\begin{array}{llllll}\mathrm{N} 3 & 2 & 0.81337671 & 0.82146793 & 0.70268424\end{array}$

N4 $\quad \begin{array}{lllll}2 & 0.30951662 & 0.73523238 & 0.22573042\end{array}$

$\begin{array}{llllll}\mathrm{C} 1 & & 3 & 0.09333797 & 0.77835184 & -0.00449989\end{array}$

$\begin{array}{llllll}\mathrm{C} 2 & 3 & 0.18783587 & 0.84393802 & -0.02419209\end{array}$

$\begin{array}{llllll}\mathrm{C} 3 & & 3 & 0.16209973 & 0.77357261 & -0.18368094\end{array}$

$\begin{array}{llllll}\mathrm{C} 4 & 3 & 0.22221438 & 0.84152482 & -0.11377851\end{array}$ 


\begin{tabular}{|c|c|c|c|c|}
\hline $\mathrm{c5}$ & J & 0.03323512 & 0.71038665 & -0.07441054 \\
\hline 66 & & 0.06761363 & 0.70797346 & -0.16399695 \\
\hline & & 0.05612317 & 0.77949983 & 0.08861311 \\
\hline 8 & & 0.59691359 & 0.71354831 & 0.93080950 \\
\hline 9 & & 0.69446745 & 0.65840440 & 0.95054288 \\
\hline 10 & & 0.66073728 & 0.69451007 & \\
\hline 11 & 3 & 0.72637560 & 0.64890909 & 1.0408291 \\
\hline & & 0.53128603 & 0.75916233 & \\
\hline & 3 & 0.56319417 & 0.74966702 & \\
\hline 14 & 3 & 0.56219090 & 0.72455296 & 0. \\
\hline & 3 & 0.90945644 & 0.79282166 & 8095 \\
\hline 16 & 3 & 0.8119 & 0.84796558 & \\
\hline 7 & & & 85990 & \\
\hline & 3 & 0.7 & 6088 & \\
\hline & 3 & 0.9 & 20765 & \\
\hline & 3 & & 570296 & \\
\hline 21 & 3 & 0.9 & 181701 & 801 \\
\hline 22 & & 0.41 & 01813 & 0.4 \\
\hline & 3 & & 0.6 & 0.4 \\
\hline & 3 & & 9736 & \\
\hline & 3 & & & \\
\hline & 3 & & & \\
\hline 27 & 5 & & 39652 & 0.3 \\
\hline 28 & & & 7014 & \\
\hline & & 0.2 & & \\
\hline $\mathrm{H} 2$ & 4 & -0.0 & 6918 & -0 . \\
\hline 13 & 4 & & 49203 & -0.2 \\
\hline H4 & 4 & 0.15 & 209290 & -0.3 \\
\hline H5 & 4 & 0.26517399 & 0.81863041 & -0.2 \\
\hline 16 & 4 & 0.21 & 5656 & 0.1 \\
\hline I7 & 4 & -0.0 & 3240 & \\
\hline H8 & 4 & 0.802 & 5032 & 1.0 \\
\hline H9 & 4 & 0.45538780 & 0.80427062 & 0.98 \\
\hline H10 & & 0.51159909 & 0.78581614 & 58506 \\
\hline & 4 & & 777462 & 1.25 \\
\hline & & 0.76 & 94915 & 1.21 \\
\hline HIJ & 4 & 0.72694361 & 0.61846437 & 0.8232626 \\
\hline H14 & 4 & 0.44100587 & 0.69285480 & 0.7638774 \\
\hline & 4 & 0.70418712 & 0.90041965 & 0.555727 \\
\hline & & 1.050 & 0.70209936 & 0.488219 \\
\hline & & 0.99477093 & 0.72055385 & \\
\hline & & 0.86083352 & 0.78859537 & 0.753760 \\
\hline H19 & 4 & 0.74284348 & 0.86142082 & 0.717002 \\
\hline $\mathrm{H} 20$ & 4 & 0.77942641 & 0.88790559 & 0.323262 \\
\hline $\mathrm{H} 21$ & + & 1.06536415 & 0.81351517 & 0.263877 \\
\hline $\mathrm{H} 22$ & 4 & 0.21074488 & 0.61369265 & 0.371349 \\
\hline
\end{tabular}




$\begin{array}{lllll}\mathrm{H} 23 & 4 & 0.54644675 & 0.84960080 & 0.43881394 \\ \mathrm{H} 24 & 4 & 0.48603657 & 0.85187794 & 0.28233991 \\ \mathrm{H} 25 & 4 & 0.35298340 & 0.78427708 & 0.17512549 \\ \mathrm{H} 26 & 4 & 0.24119604 & 0.68773956 & 0.21143859 \\ \mathrm{H} 27 & 4 & 0.29308845 & 0.59461341 & 0.60168524 \\ \mathrm{H} 28 & 4 & 0.57531631 & 0.70003756 & 0.65742124 \\ \text { END } & & & & \end{array}$

TITL CE

$\begin{array}{lllllll}\text { CELL 1.0 } & 15.5222 & 8.5864 & 11.3064 & 88.8204 & 90.0000 & 90.0000\end{array}$

ZERR 80.00 .00 .00 .00 .00 .0

LATT 1

$\mathrm{SYMM}+\mathrm{X}+1 / 2,-\mathrm{Y}+1 / 2,-\mathrm{Z}$

SFAC O N C H

$\begin{array}{llllll}\mathrm{O} 1 & & 1 & 0.84556045 & 0.40902753 & 0.60563418\end{array}$

$\begin{array}{llllll}\mathrm{O} 2 & & 1 & 0.89868266 & 0.69575745 & 0.88069613\end{array}$

$\begin{array}{llllll}\mathrm{O} 3 & & 1 & 0.93797093 & 0.65731751 & 0.68983314\end{array}$

$\begin{array}{llllll}\text { O4 } & 1 & 0.17812958 & 0.17560085 & 0.88324107\end{array}$

$\begin{array}{llllll}\text { O5 } & & 1 & 0.09058296 & 0.46855782 & 0.61993862\end{array}$

$\begin{array}{llllll}\text { O6 } & & 1 & 0.07576047 & 0.42502363 & 0.81788274\end{array}$

$\begin{array}{lllll}\mathrm{N} 1 & 2 & 0.81713827 & -0.02197695 & 0.88107709\end{array}$

$\begin{array}{lllll}\mathrm{N} 2 & 2 & 0.17330101 & -0.24844440 & 0.61218148\end{array}$

$\begin{array}{llllll}\mathrm{C} 1 & 3 & 0.88582974 & 0.44330922 & 0.80825435\end{array}$

$\begin{array}{llllll}\mathrm{C} 2 & 3 & 0.85444022 & 0.35061527 & 0.71796877\end{array}$

$\begin{array}{llllll}\mathrm{C} 3 & 3 & 0.84018861 & 0.13426217 & 0.85660436\end{array}$

$\begin{array}{llllll}\mathrm{C} 4 & 3 & 0.83162558 & 0.19607886 & 0.74215812\end{array}$

$\begin{array}{llllll}\mathrm{C} 5 & 3 & 0.89440293 & 0.38146442 & 0.92270315\end{array}$

$\begin{array}{llllll}\text { C6 } & & 3 & 0.87158523 & 0.22696213 & 0.94687178\end{array}$

$\begin{array}{lllll}\text { C7 } & 3 & 0.91008488 & 0.60488001 & 0.78478167\end{array}$

$\begin{array}{llllll}\mathrm{C} 8 & 3 & 0.11311560 & 0.21442346 & 0.69244788\end{array}$

$\begin{array}{llllll}\text { C9 } & 3 & 0.15559441 & 0.11983320 & 0.77557601\end{array}$

$\begin{array}{llllll}\mathrm{C} 10 & 3 & 0.15310913 & -0.09301765 & 0.63914977\end{array}$

$\begin{array}{llllll}\mathrm{C} 11 & 3 & 0.17558359 & -0.03389995 & 0.74891442\end{array}$

$\begin{array}{llllll}\mathrm{C} 12 & 3 & 0.09063091 & 0.15527760 & 0.58268355\end{array}$

$\begin{array}{llllll}\mathrm{C} 13 & 3 & 0.11062557 & 0.00157810 & 0.55604110\end{array}$

$\begin{array}{llllll}\mathrm{C} 14 & 3 & 0.09159418 & 0.37519467 & 0.71862604\end{array}$

$\begin{array}{llllll}\mathrm{H} 1 & 4 & 0.80727475 & 0.12468411 & 0.67172726\end{array}$

$\begin{array}{lllll}\mathrm{H} 2 & 4 & 0.91933095 & 0.45003544 & 0.99438560\end{array}$

$\begin{array}{lllll}\mathrm{H} 3 & 4 & 0.87868574 & 0.18017262 & 1.03602257\end{array}$

$\begin{array}{lllll}\mathrm{H} 4 & 4 & 0.82326103 & -0.06674286 & 0.96386312\end{array}$

$\begin{array}{lllll}\text { H5 } & 4 & 0.79438767 & -0.08907281 & 0.81584444\end{array}$

$\begin{array}{llllll}\text { H6 } & 4 & 0.86062375 & 0.51937980 & 0.60198768\end{array}$

$\begin{array}{lllll}\mathrm{H} 7 & 4 & 0.91572361 & 0.80808630 & 0.86352239\end{array}$

$\begin{array}{lllll}\mathrm{H} 8 & 4 & 0.20858398 & -0.10677524 & 0.81377871\end{array}$

$\begin{array}{lllll}\mathrm{H} 9 & 4 & 0.05691556 & 0.22535315 & 0.51676751\end{array}$

$\begin{array}{lllll}\mathrm{H} 10 & 4 & 0.09269013 & -0.04311324 & 0.47061574\end{array}$ 


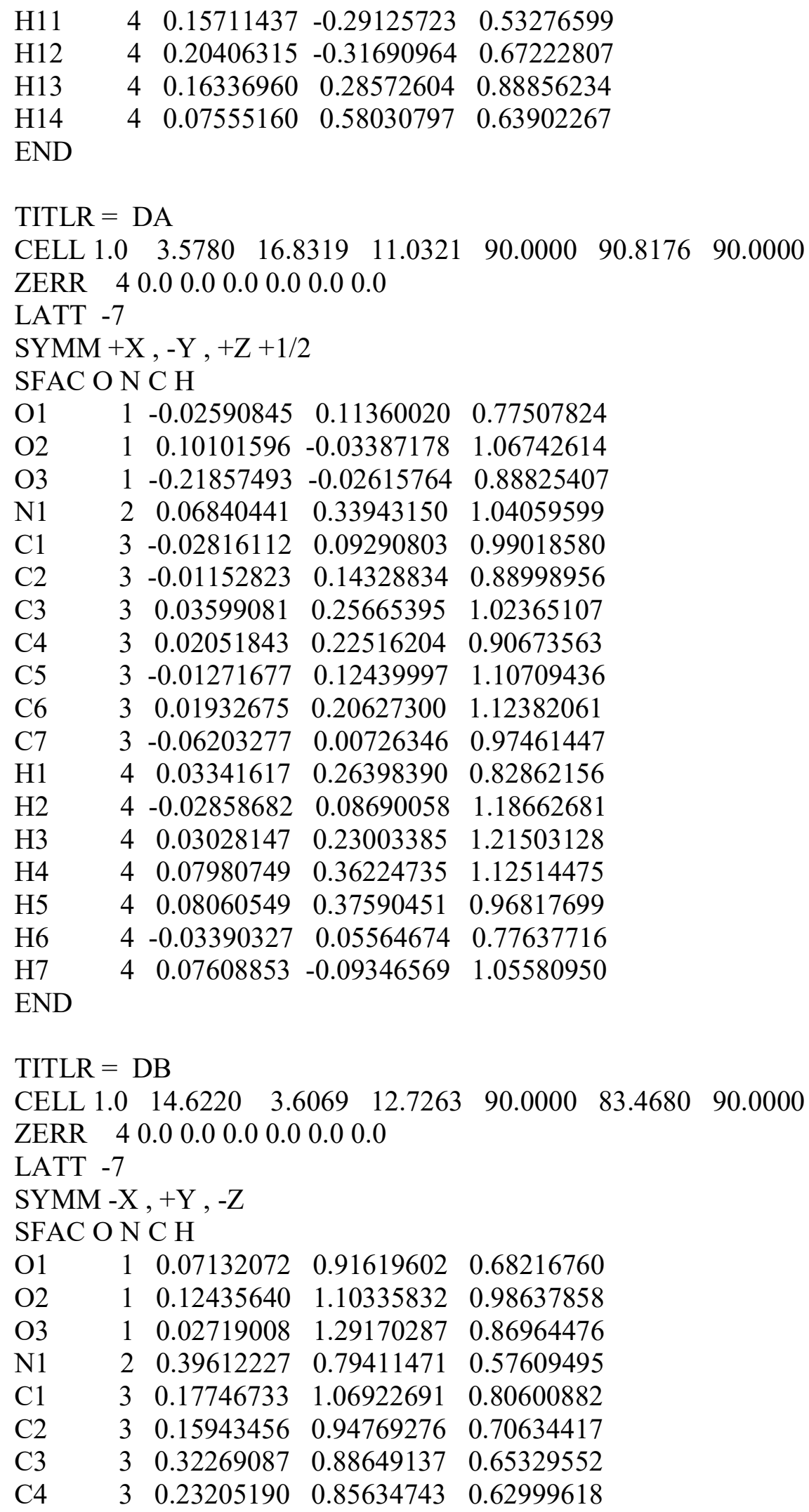




\begin{tabular}{|c|c|c|c|c|}
\hline $\mathrm{C} 5$ & $\begin{array}{ll}3 & 0.26809583\end{array}$ & 1.09936792 & 0.82929927 & \\
\hline C6 & $\begin{array}{ll}3 & 0.34072359\end{array}$ & 1.00802966 & 0.75294976 & \\
\hline $\mathrm{C} 7$ & $\begin{array}{ll}3 & 0.10260874\end{array}$ & 1.16631379 & 0.88677947 & \\
\hline H1 & $4 \quad 0.21763972$ & 0.76206007 & 0.55277788 & \\
\hline $\mathrm{H} 2$ & $4 \quad 0.28433004$ & 1.19621570 & 0.90556782 & \\
\hline H3 & $4 \quad 0.41081157$ & 1.03329416 & 0.77189142 & \\
\hline $\mathrm{H} 4$ & $4 \quad 0.46170106$ & 0.81566557 & 0.59292010 & \\
\hline H5 & $4 \quad 0.38313225$ & 0.70604782 & 0.50401489 & \\
\hline H6 & $4 \quad 0.02744017$ & 0.97492133 & 0.74354111 & \\
\hline $\mathrm{H} 7$ & $4 \quad 0.07181489$ & 1.17174711 & 1.04211519 & \\
\hline \multicolumn{5}{|l|}{ END } \\
\hline \multicolumn{5}{|c|}{ TITLR = DC } \\
\hline CELL 1. & $\begin{array}{lll}0 & 13.8080 & 3.5\end{array}$ & $5884 \quad 26.7601$ & $90.0000 \quad 103.0586$ & 90.0000 \\
\hline ZERR & \multicolumn{4}{|c|}{80.00 .00 .00 .00 .00 .0} \\
\hline LATT 7 & \multicolumn{4}{|c|}{7} \\
\hline \multirow{2}{*}{\multicolumn{5}{|c|}{$\begin{array}{l}\text { SYMM -X },+Y,-Z+1 / 2 \\
\text { SFAC O N C H }\end{array}$}} \\
\hline & & & & \\
\hline $\mathrm{O} 1$ & 10.47443387 & 0.15608132 & 0.83773772 & \\
\hline $\mathrm{O} 2$ & 10.61826076 & -0.11897327 & 0.98401897 & \\
\hline $\mathrm{O} 3$ & 10.48654126 & 0.22254252 & 0.94155781 & \\
\hline N1 & 20.78911485 & 0.20742286 & 0.78950365 & \\
\hline $\mathrm{C} 1$ & 30.62472473 & 0.11607863 & 0.90321632 & \\
\hline $\mathrm{C} 2$ & 30.57565840 & 0.15118261 & 0.85180190 & \\
\hline $\mathrm{C} 3$ & $3 \quad 0.73389470$ & 0.17677692 & 0.82768741 & \\
\hline $\mathrm{C} 4$ & 30.63025724 & 0.18154637 & 0.81403894 & \\
\hline $\mathrm{C} 5$ & $\begin{array}{ll}3 & 0.72836070\end{array}$ & 0.11131207 & 0.91685307 & \\
\hline C6 & $\begin{array}{ll}3 & 0.78295226\end{array}$ & 0.14169234 & 0.87909763 & \\
\hline $\mathrm{C} 7$ & $\begin{array}{ll}3 & 0.56905775\end{array}$ & 0.08443500 & 0.94322270 & \\
\hline H1 & $4 \quad 0.59176701$ & 0.20864048 & 0.77419094 & \\
\hline $\mathrm{H} 2$ & $4 \quad 0.76857221$ & 0.08801325 & 0.95646370 & \\
\hline $\mathrm{H} 3$ & $4 \quad 0.86339192$ & 0.13840288 & 0.89016995 & \\
\hline $\mathrm{H} 4$ & 40.86409003 & 0.20380659 & 0.79934853 & \\
\hline H5 & $4 \quad 0.75368264$ & 0.23270557 & 0.75231206 & \\
\hline H6 & $4 \quad 0.44569900$ & 0.11858998 & 0.86749846 & \\
\hline H7 & $4 \quad 0.57893391$ & -0.13957607 & 1.01168708 & \\
\hline \multicolumn{5}{|c|}{ מ } \\
\hline \multicolumn{5}{|c|}{ TITLR $=$ DD } \\
\hline CELL 1. & $\begin{array}{lll}0 & 13.7913 & 8.0\end{array}$ & $0135 \quad 14.8295$ & $90.0000 \quad 62.1345$ & 90.0000 \\
\hline \multicolumn{5}{|c|}{ ZERR $\quad 8 \quad 0.0 \quad 0.0 \quad 0.0 \quad 0.0 \quad 0.0 \quad 0.0$} \\
\hline \multicolumn{5}{|c|}{ LATT 7} \\
\hline \multicolumn{5}{|c|}{ SYMM -X $,+Y,-Z+1 / 2$} \\
\hline \multicolumn{5}{|c|}{ SFAC O N C H } \\
\hline $\mathrm{O} 1$ & 10.39470482 & 1.43373242 & 0.97768349 & \\
\hline $\mathrm{O} 2$ & 10.16511725 & 1.41411981 & 0.87669454 & \\
\hline
\end{tabular}




$\begin{array}{lllll}\text { O3 } & 1 & 0.29993506 & 1.25565100 & 0.88032212 \\ \text { N1 } & 2 & 0.45335368 & 2.01474893 & 0.88734779 \\ \text { C1 } & 3 & 0.31135763 & 1.55339234 & 0.88243899 \\ \text { C2 } & 3 & 0.37639953 & 1.56787158 & 0.93117363 \\ \text { C3 } & 3 & 0.40567487 & 1.85982358 & 0.88570293 \\ \text { C4 } & 3 & 0.42355449 & 1.72108905 & 0.93280482 \\ \text { C5 } & 3 & 0.29348806 & 1.69213256 & 0.83533676 \\ \text { C6 } & 3 & 0.34064029 & 1.84534064 & 0.83696986 \\ \text { C7 } & 3 & 0.26148188 & 1.39448481 & 0.87980805 \\ \text { H1 } & 4 & 0.47394460 & 1.73159420 & 0.97077496 \\ \text { H2 } & 4 & 0.24427977 & 1.68447988 & 0.79606733 \\ \text { H3 } & 4 & 0.32636346 & 1.95208129 & 0.79994814 \\ \text { H4 } & 4 & 0.44040278 & 2.11517060 & 0.85333728 \\ \text { H5 } & 4 & 0.50036280 & 2.02533122 & 0.92261871 \\ \text { H6 } & 4 & 0.35380853 & 1.33669165 & 0.97421723 \\ \text { H7 } & 4 & 0.13097025 & 1.30280098 & 0.87486428 \\ \text { END } & & & & \end{array}$

TITLR $=$ DE

$\begin{array}{lllllll}\text { CELL 1.0 } & 24.0835 & 7.4280 & 13.2080 & 90.0000 & 40.2054 & 90.0000\end{array}$ ZERR $\quad 80.00 .00 .00 .00 .00 .0$

LATT 7

SYMM -X, + Y , $-Z+1 / 2$

SFAC O N C H

$\begin{array}{llllll}\mathrm{O} 1 & 1 & 0.13011861 & 0.26953430 & 0.20558276\end{array}$

$\begin{array}{lllll}\mathrm{O} 2 & 1 & 0.17985247 & -0.19075780 & -0.02319219\end{array}$

$\begin{array}{lllll}\text { O3 } & 1 & 0.22692175 & -0.03900203 & 0.05008033\end{array}$

$\begin{array}{lllll}\mathrm{N} 1 & 2 & 0.07244187 & 0.57933142 & -0.02639902\end{array}$

$\begin{array}{llllll}\mathrm{C} 1 & & 3 & 0.16140355 & 0.12205096 & 0.00473073\end{array}$

$\begin{array}{lllll}\mathrm{C} 2 & 3 & 0.13125885 & 0.27049798 & 0.10082567\end{array}$

$\begin{array}{llllll}\mathrm{C} 3 & 3 & 0.10231401 & 0.42577787 & -0.01593608\end{array}$

$\begin{array}{lllll}\mathrm{C} 4 & 3 & 0.10171827 & 0.42236312 & 0.09047972\end{array}$

$\begin{array}{llllll}\text { C5 } & 3 & 0.16198907 & 0.12548581 & -0.10167626\end{array}$

$\begin{array}{llllll}\text { C6 } & 3 & 0.13245781 & 0.27734194 & -0.11202012\end{array}$

$\begin{array}{lllll}\text { C7 } & 3 & 0.19259710 & -0.03771959 & 0.01362726\end{array}$

H1 $\quad \begin{array}{lllll}4 & 0.07837216 & 0.53718795 & 0.16539617\end{array}$

$\begin{array}{llllll}\mathrm{H} 2 & 4 & 0.18575893 & 0.01308412 & -0.17887619\end{array}$

H3 $\quad 4 \quad \begin{array}{lllll}4 & 0.13339592 & 0.27856783 & -0.19531196\end{array}$

$\begin{array}{llllll}\mathrm{H} 4 & 4 & 0.07280957 & 0.58185894 & -0.10328973\end{array}$

$\begin{array}{llllll}\text { H5 } & 4 & 0.05060246 & 0.68671311 & 0.04310638\end{array}$

$\begin{array}{lllll}\text { H6 } & 4 & 0.14932489 & 0.15336112 & 0.20492886\end{array}$

$\begin{array}{lllll}\mathrm{H} 7 & 4 & 0.20177052 & -0.30134221 & -0.01667140\end{array}$

END

TITLR $=$ FA

$\begin{array}{lllllll}\text { CELL 1.0 } & 7.2523 & 26.4439 & 3.6106 & 90.0000 & 71.7833 & 90.0000\end{array}$ 


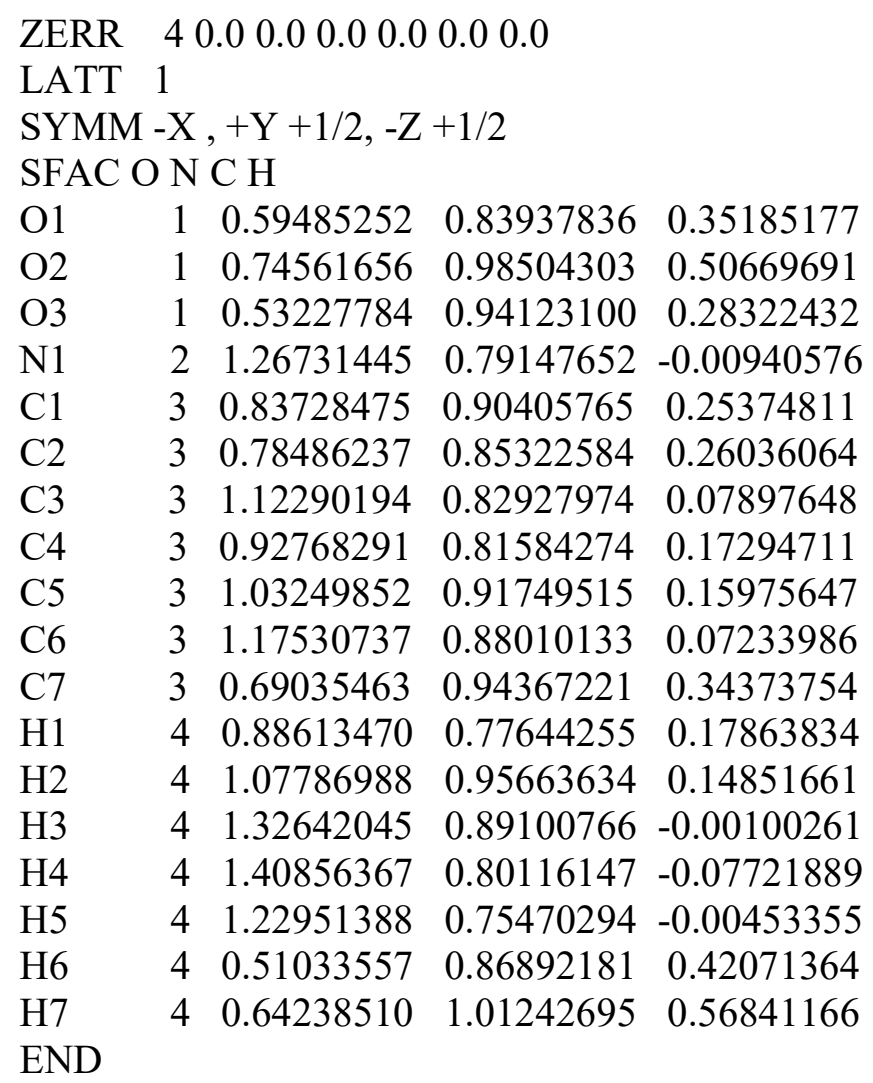

TITLR $=$ FC $\quad($ STR1 $)$

$\begin{array}{lllllll}\text { CELL 1.0 } & 6.9920 & 3.6688 & 24.8207 & 90.0000 & 90.9374 & 90.0000\end{array}$

ZERR $\quad 4 \quad 0.00 .00 .00 .00 .00 .0$

LATT 1

SYMM $-\mathrm{X}+1 / 2,+\mathrm{Y}+1 / 2,-\mathrm{Z}+1 / 2$

SFAC O N C H

$\begin{array}{lllll}\text { O1 } & 1 & 0.39990063 & -0.21134193 & 0.83237612\end{array}$

$\begin{array}{lllll}\mathrm{O} 2 & 1 & 0.27839972 & -0.24582323 & 0.99291290\end{array}$

$\begin{array}{lllll}\text { O3 } & 1 & 0.45369276 & -0.54718602 & 0.93076207\end{array}$

$\begin{array}{lllll}\mathrm{N} 1 & 2 & -0.24920445 & 0.14728602 & 0.79353062\end{array}$

$\begin{array}{llllll}\mathrm{C} 1 & & 3 & 0.17055637 & -0.22702485 & 0.90315411\end{array}$

$\begin{array}{llllll}\mathrm{C} 2 & 3 & 0.21805286 & -0.15859848 & 0.84973890\end{array}$

$\begin{array}{lllll}\text { C3 } & 3 & -0.10823190 & 0.02159902 & 0.83033892\end{array}$

$\begin{array}{llllll}\text { C4 } & 3 & 0.07862923 & -0.03431398 & 0.81331878\end{array}$

$\begin{array}{lllll}\text { C5 } & 3 & -0.01630577 & -0.17112476 & 0.92016421\end{array}$

$\begin{array}{lllll}\text { C6 } & 3 & -0.15569732 & -0.04684641 & 0.88376231\end{array}$

$\begin{array}{llllll}\text { C7 } & 3 & 0.31401239 & -0.35727439 & 0.94177344\end{array}$

$\begin{array}{llllll}\mathrm{H} 1 & 4 & 0.11633789 & 0.01844937 & 0.77189692\end{array}$

H2 $\quad 4 \quad-0.05796952 \quad-0.22510270 \quad 0.96123308$

$\begin{array}{lllll}\mathrm{H} 3 & 4 & -0.30038538 & -0.00519550 & 0.89741683\end{array}$

$\begin{array}{llllll}\mathrm{H} 4 & 4 & -0.38438191 & 0.18796263 & 0.80582010\end{array}$

$\begin{array}{llllll}\text { H5 } & 4 & -0.21494495 & 0.19696676 & 0.75488766\end{array}$ 
$\begin{array}{lllll}\text { H6 } & 4 & 0.48404907 & -0.28482068 & 0.86220030\end{array}$

$\begin{array}{lllll}\mathrm{H} 7 & 4 & 0.37903612 & -0.33779466 & 1.01952980\end{array}$

END 
Figure S6. Crystallographic autostereograms of the predicted crystal packings made with MoProViewer.

9: Katrusiak, A. (2001). Crystallographic autostereograms. Journal of Molecular Graphics and Modelling, 19(3-4), 363-367.)
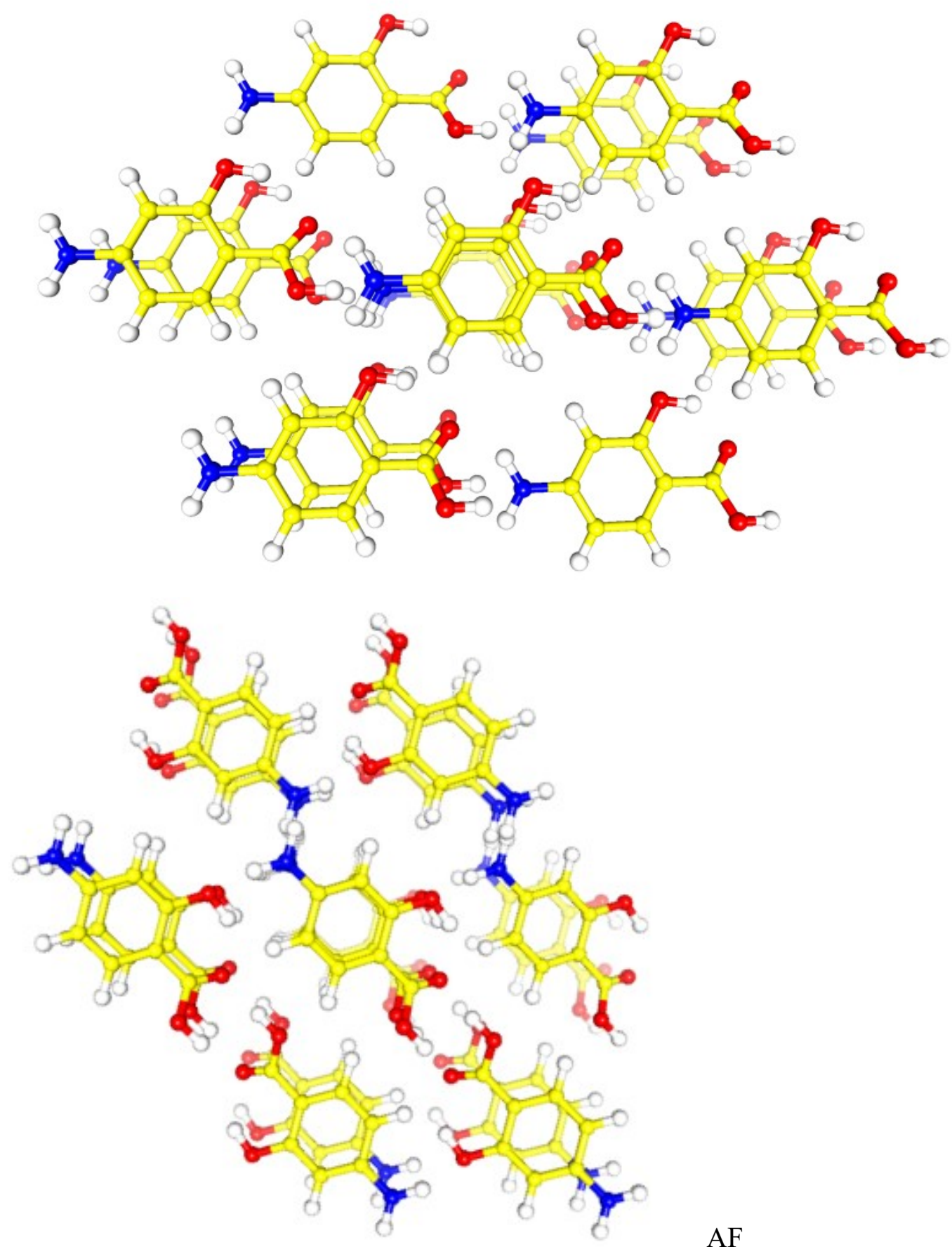

AA 


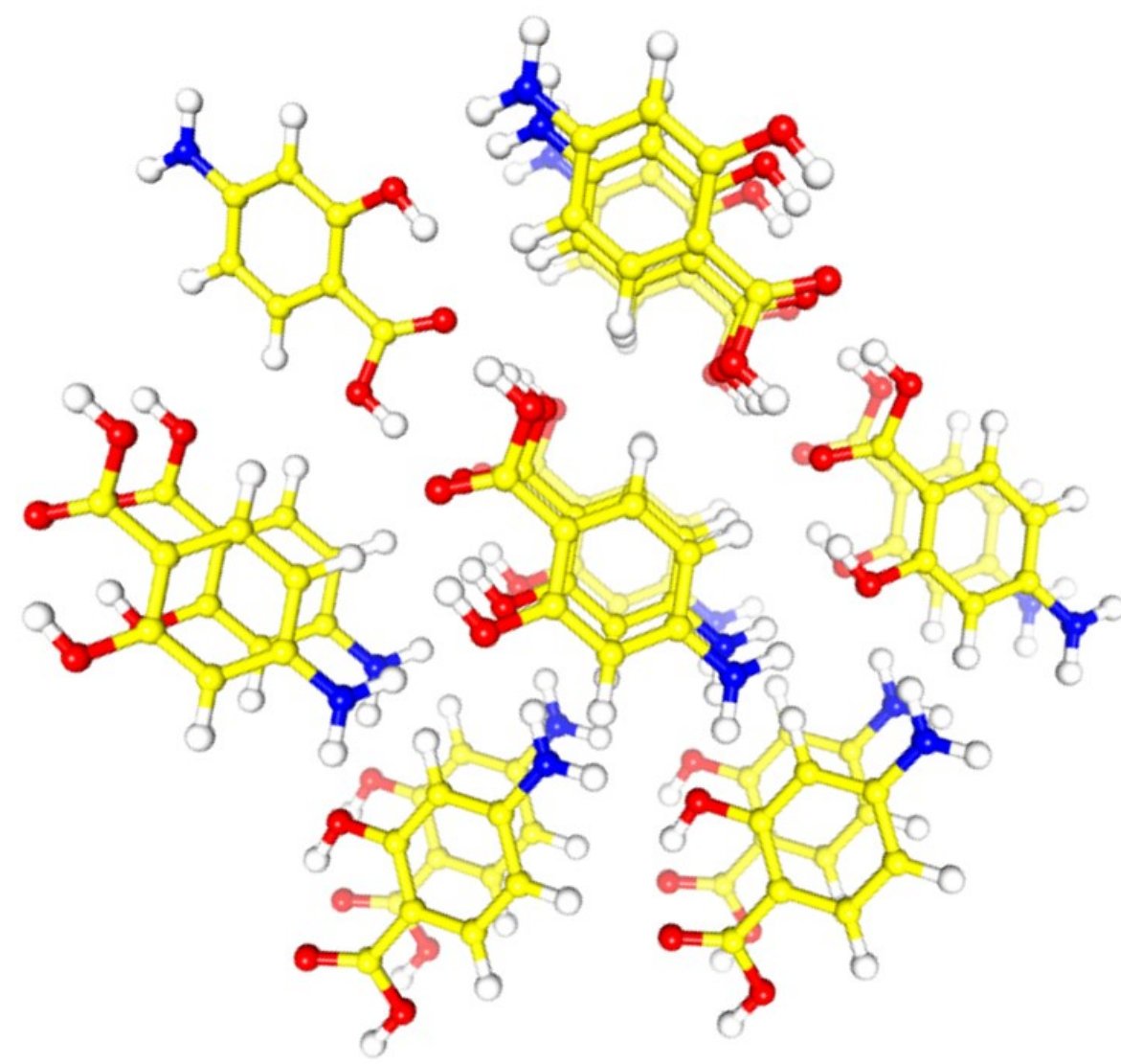




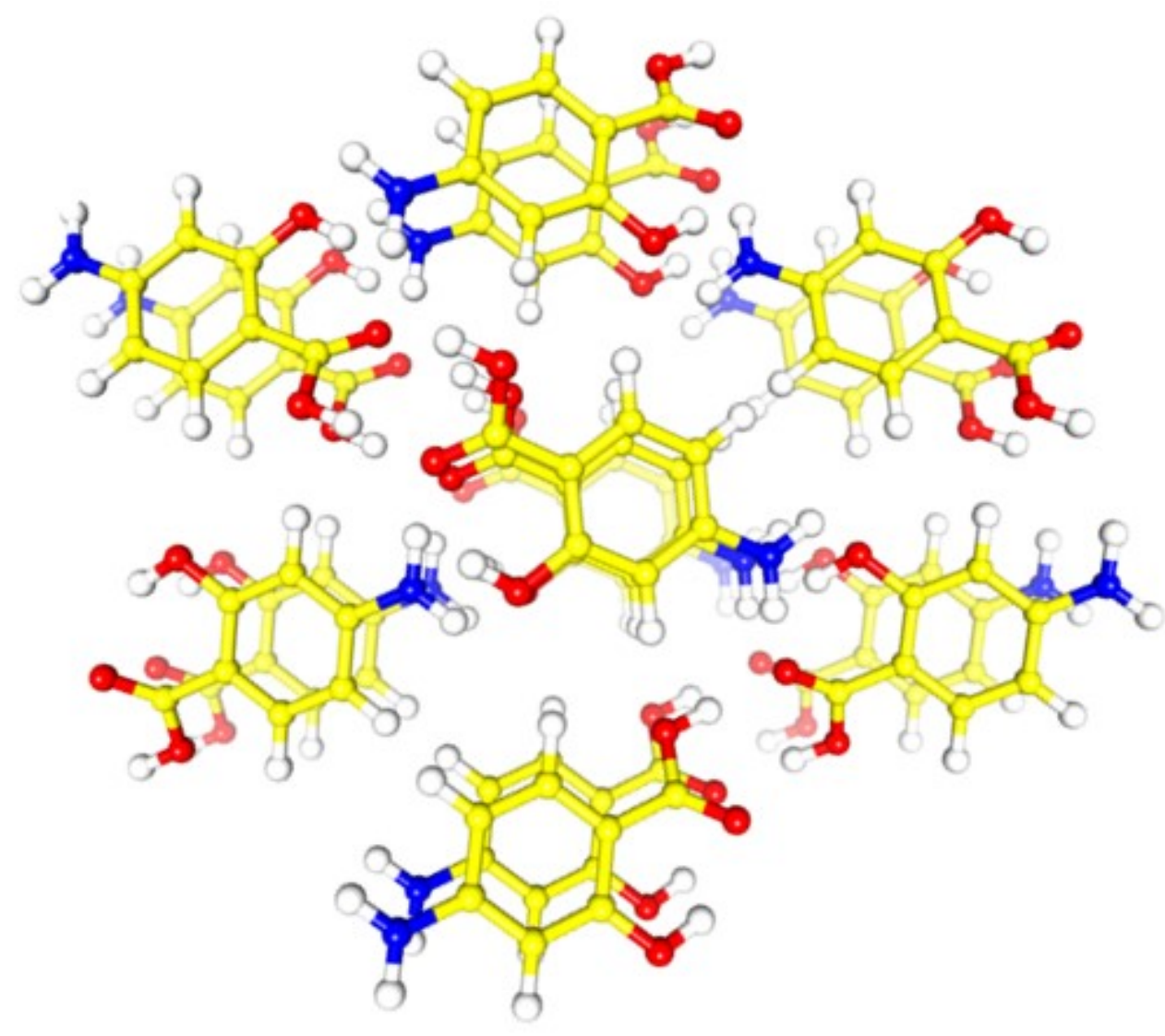

AQ
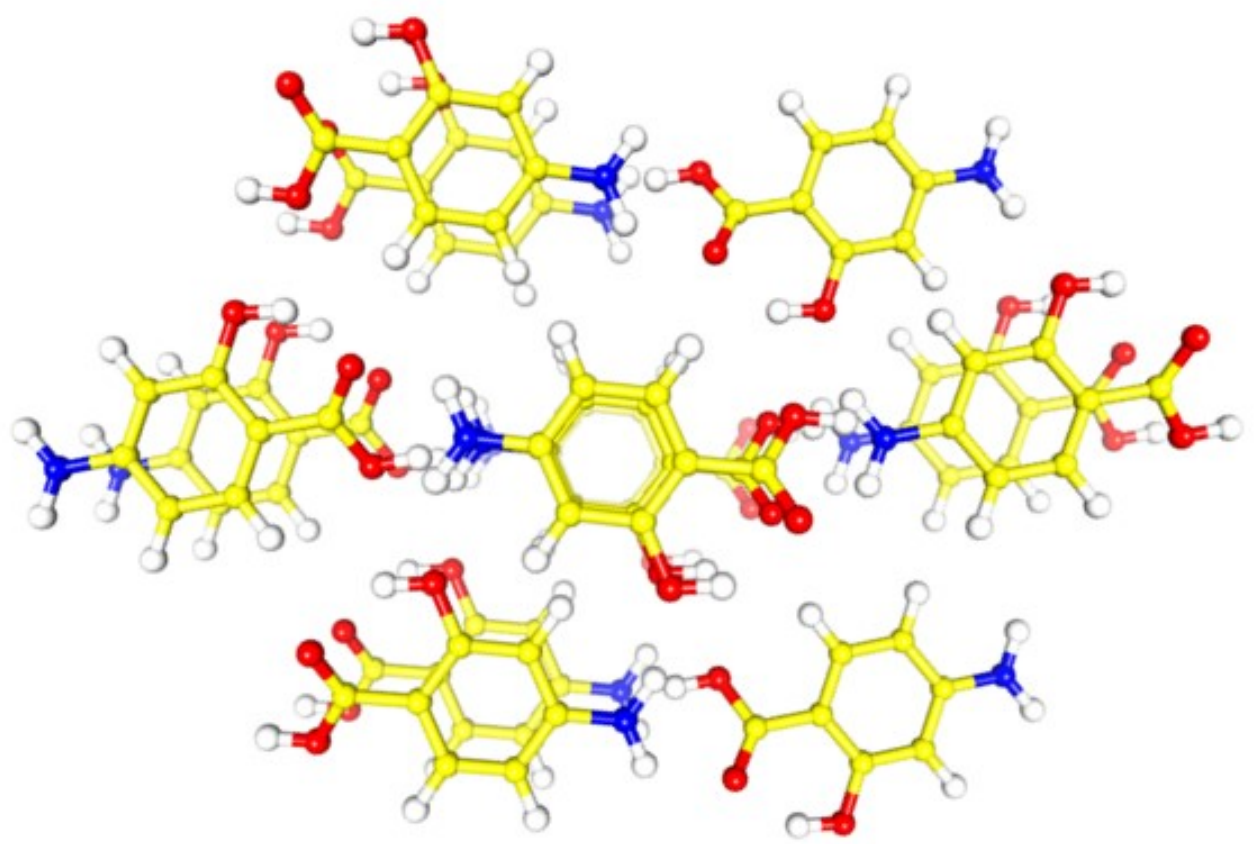


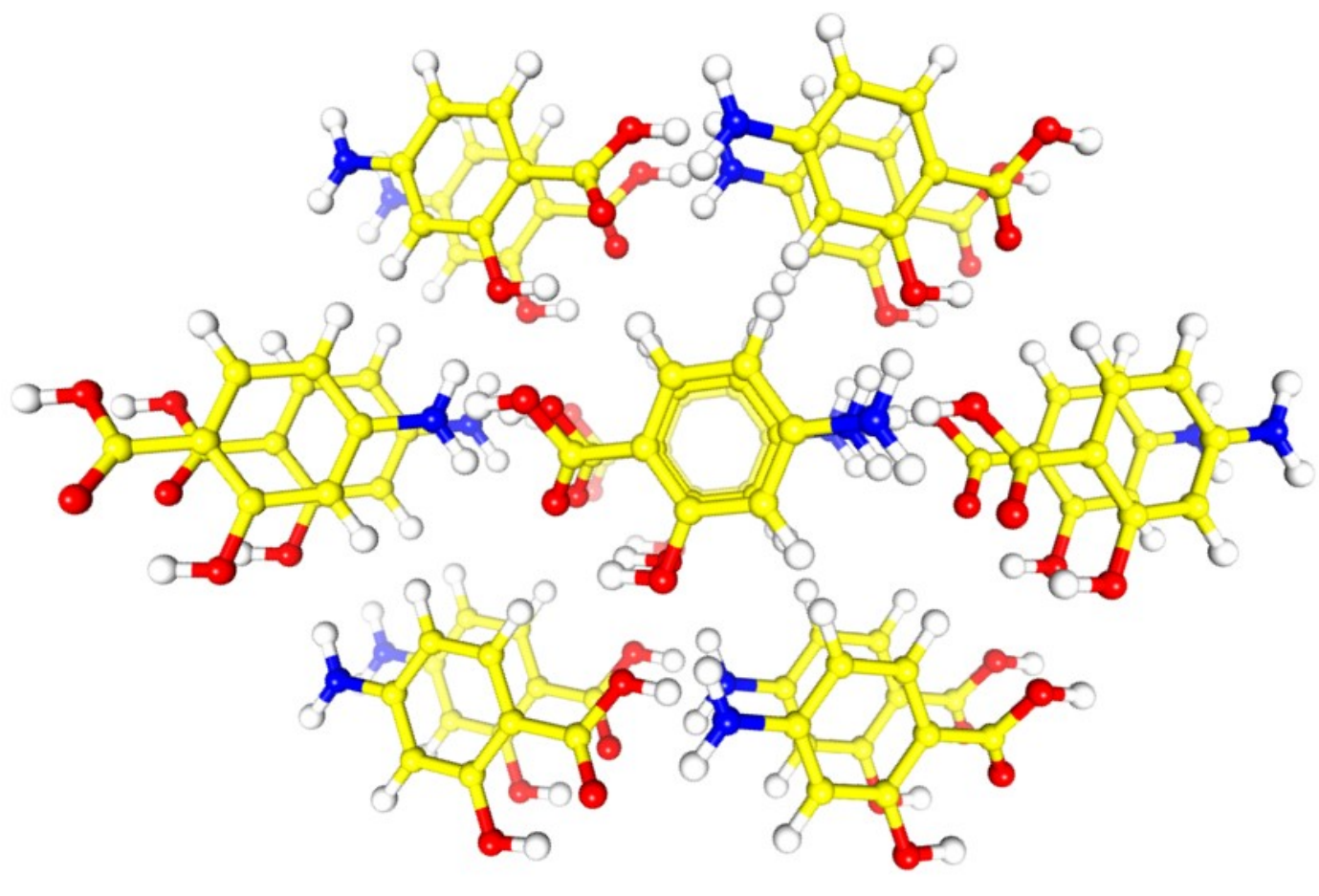




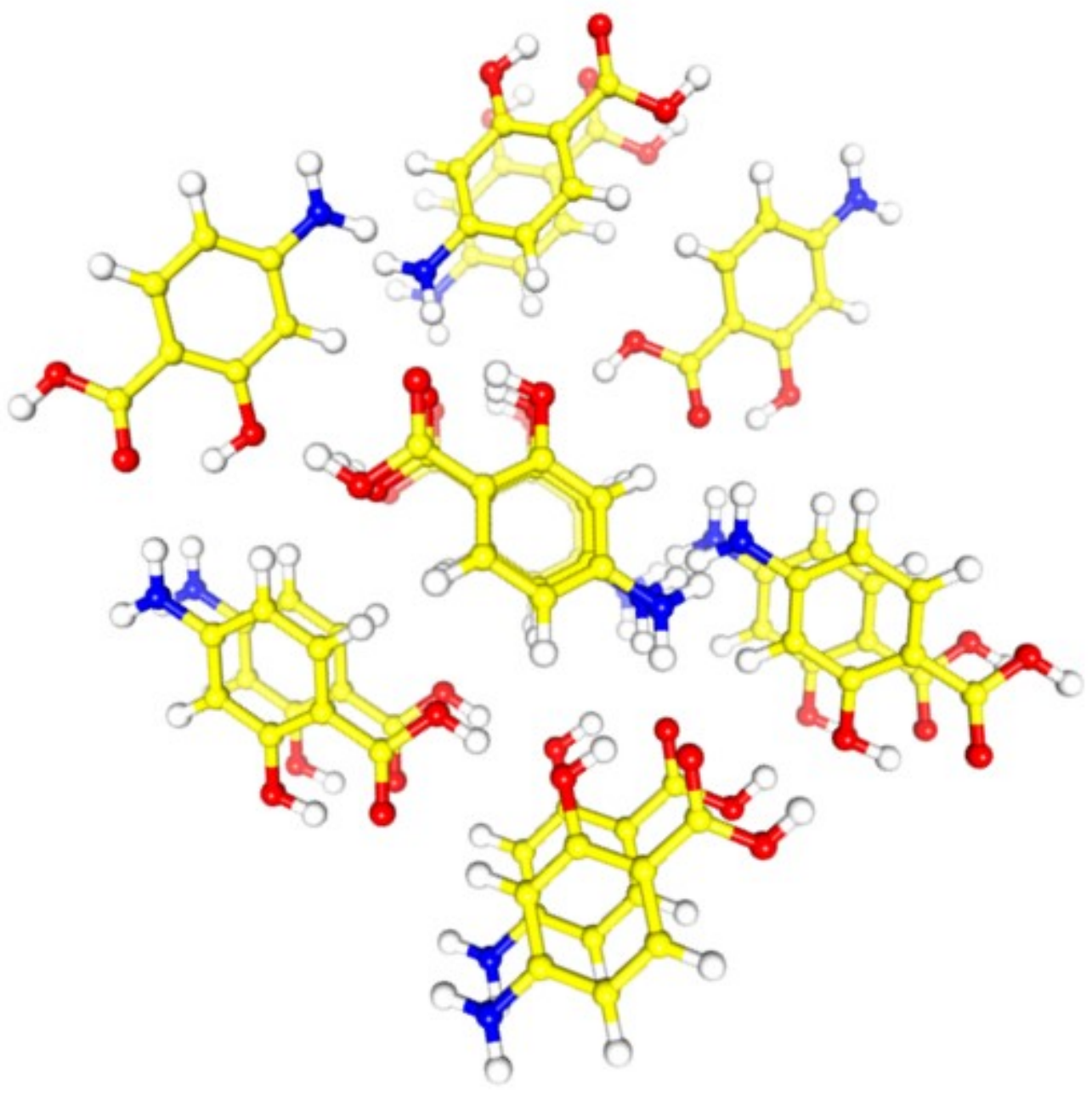



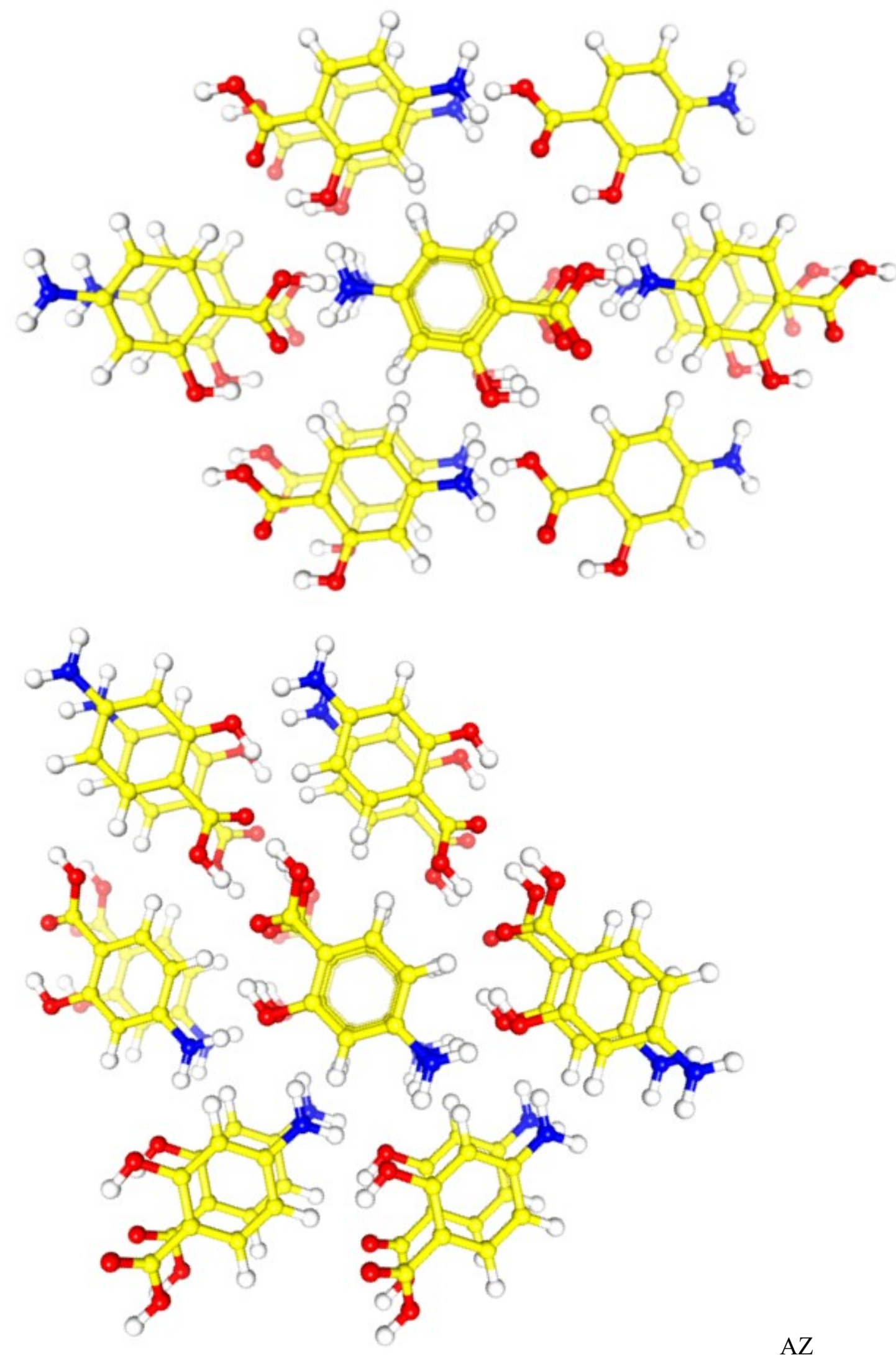


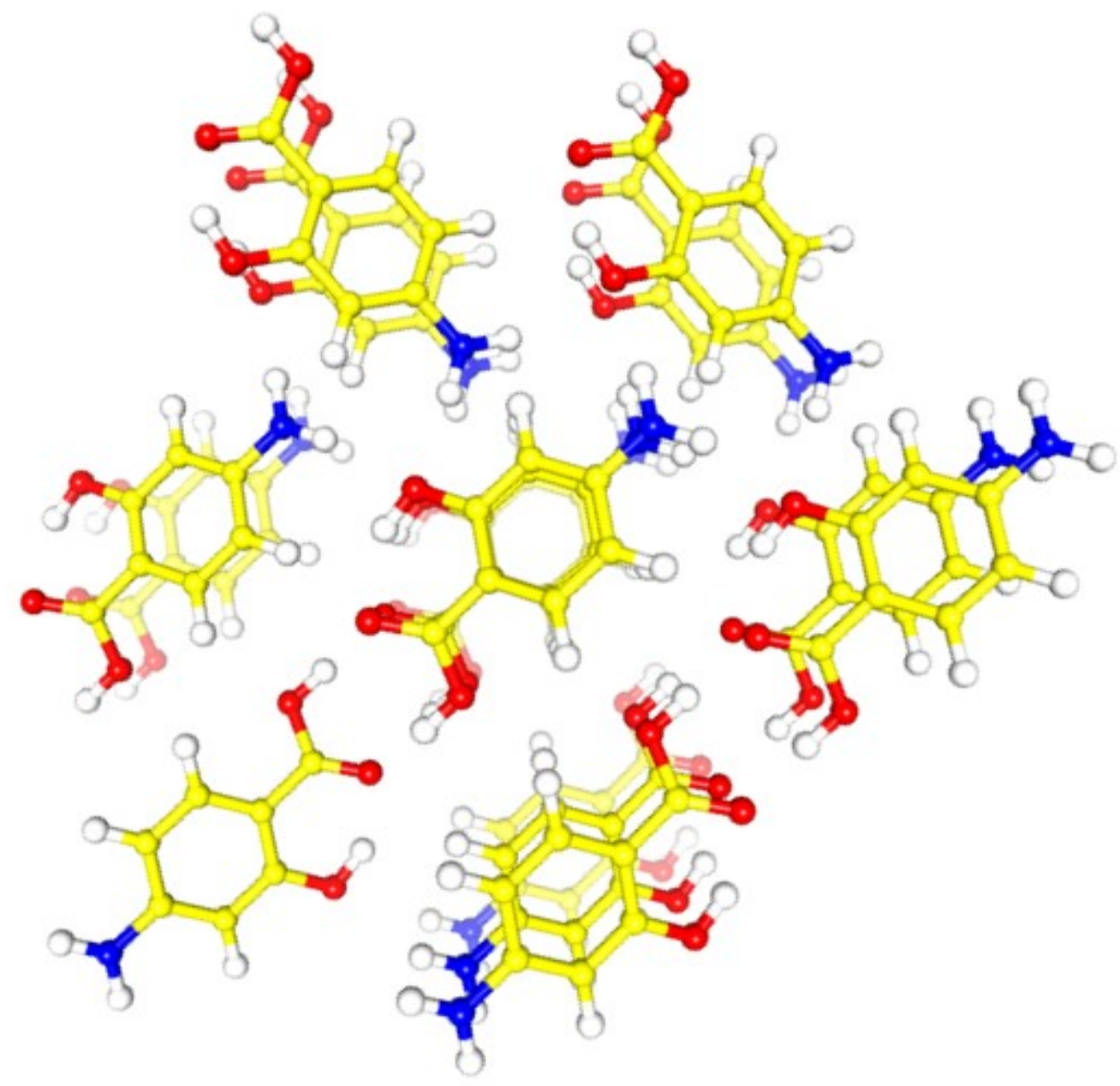

BA 

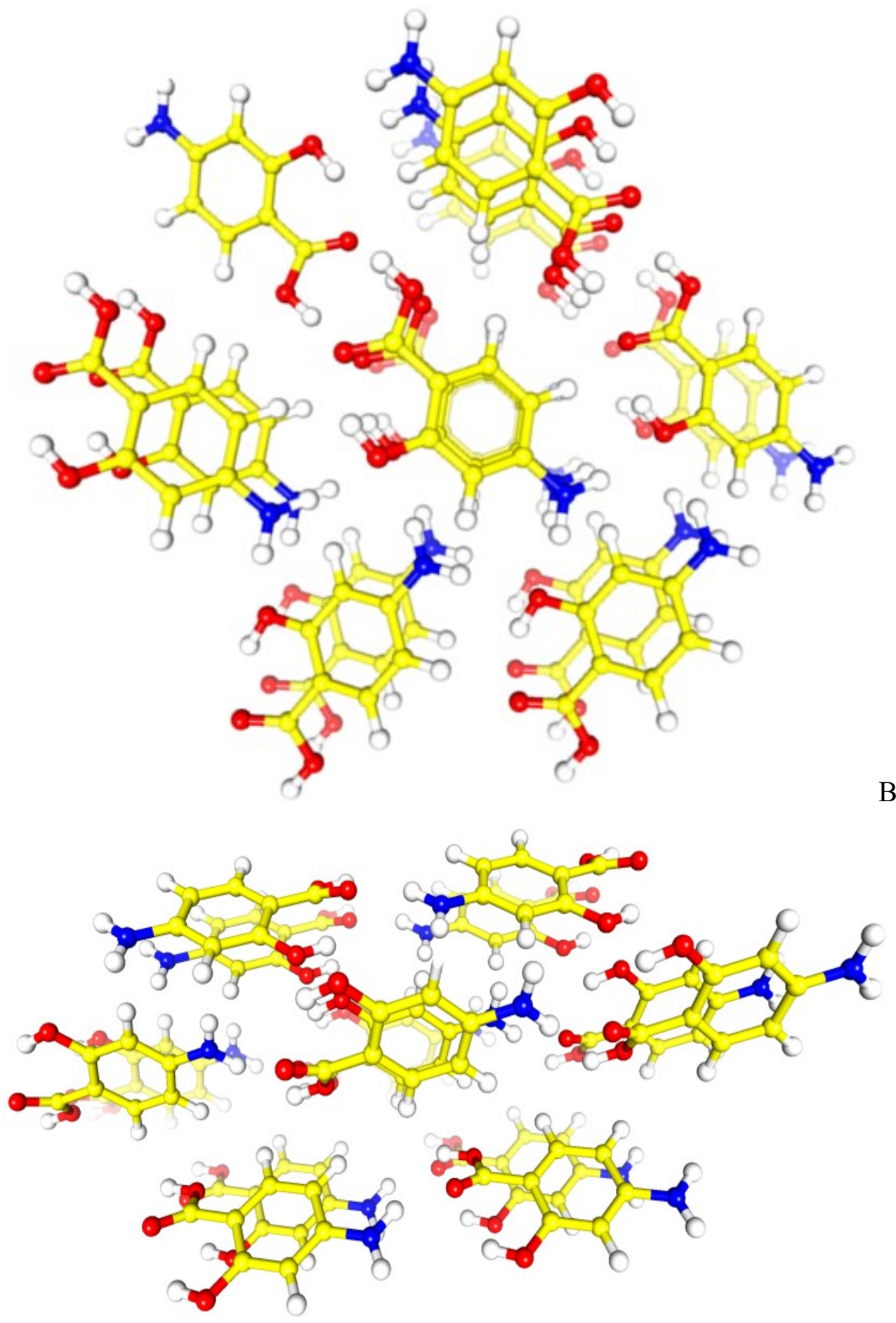

BD 


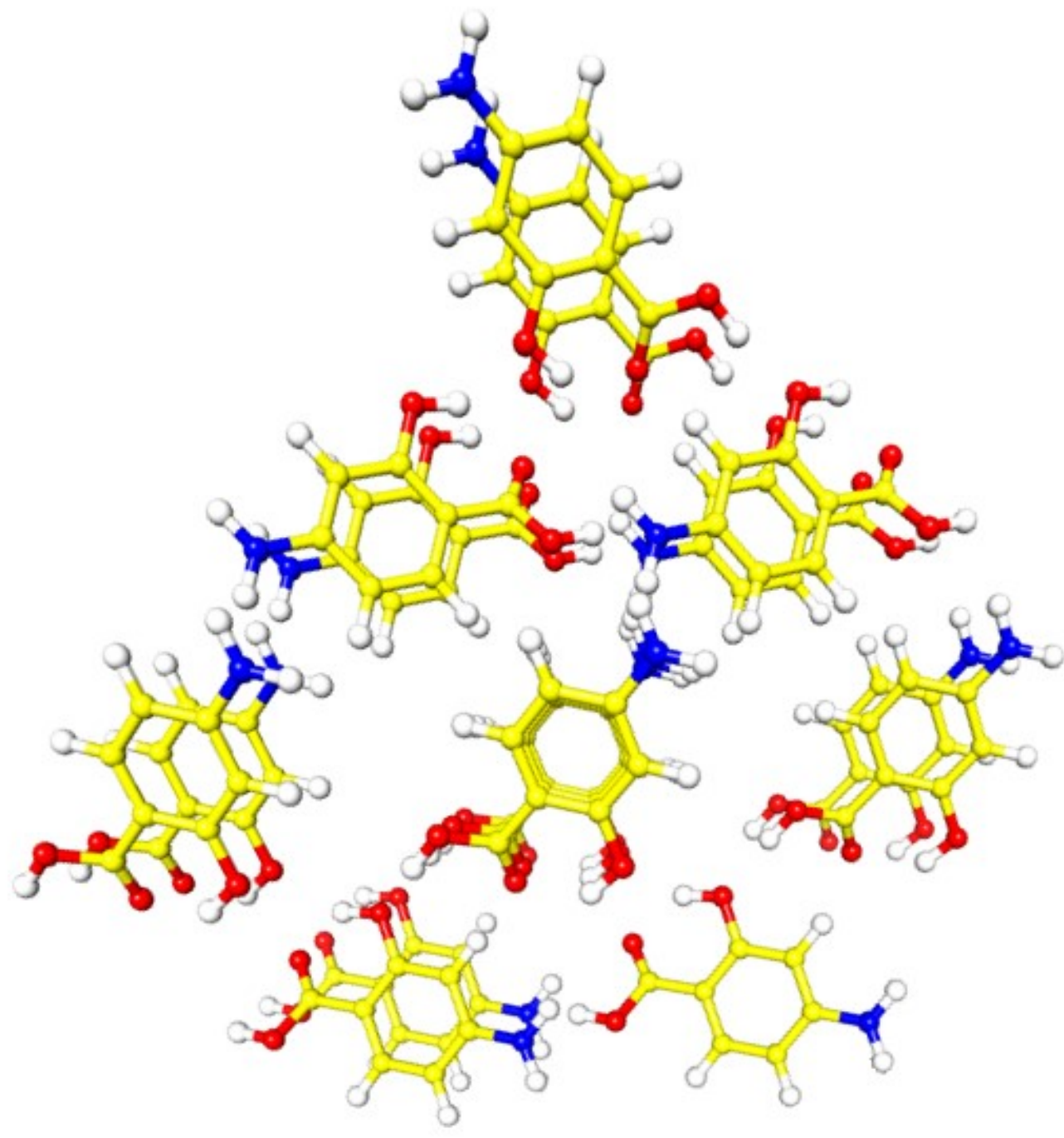




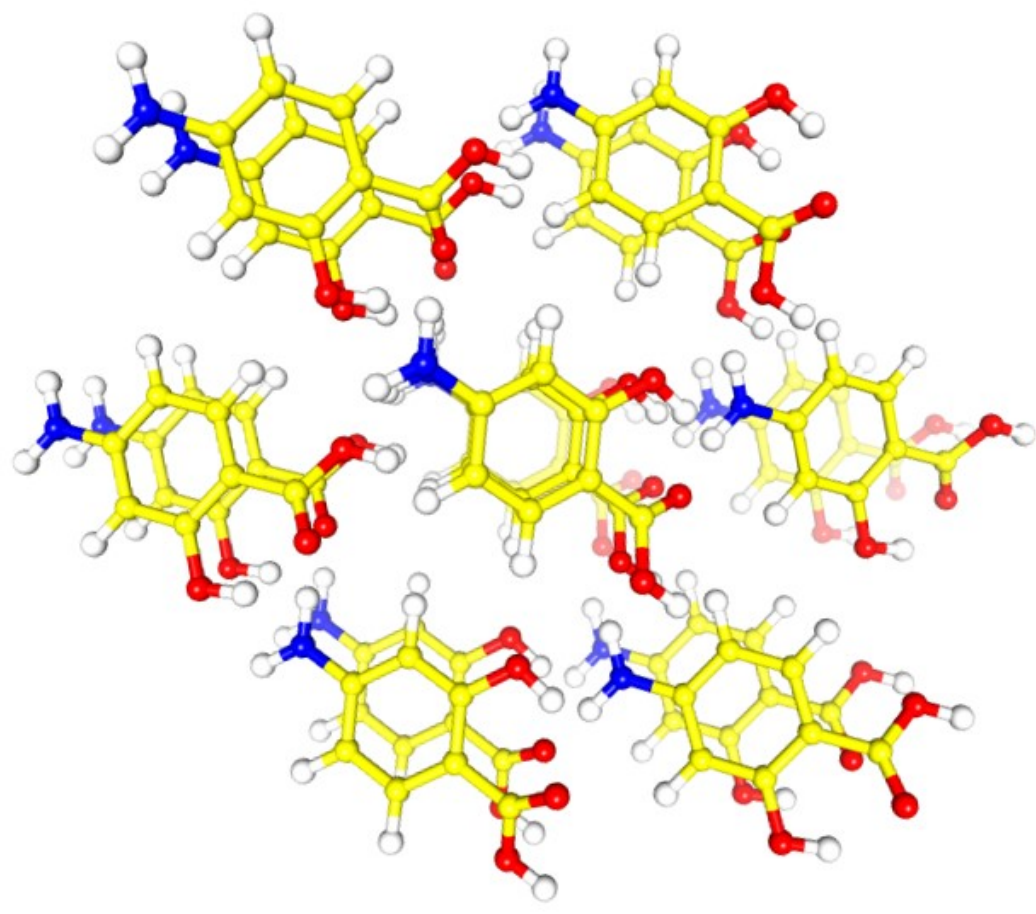

BH

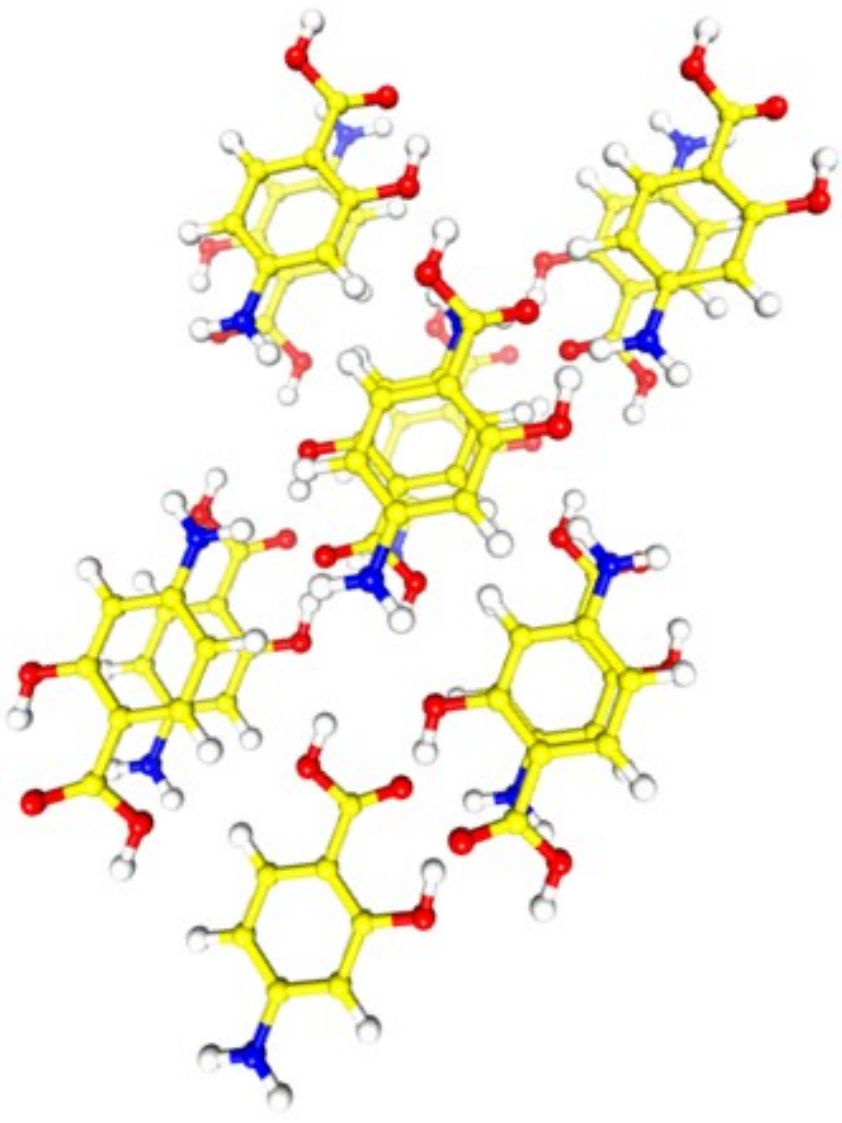

CA 

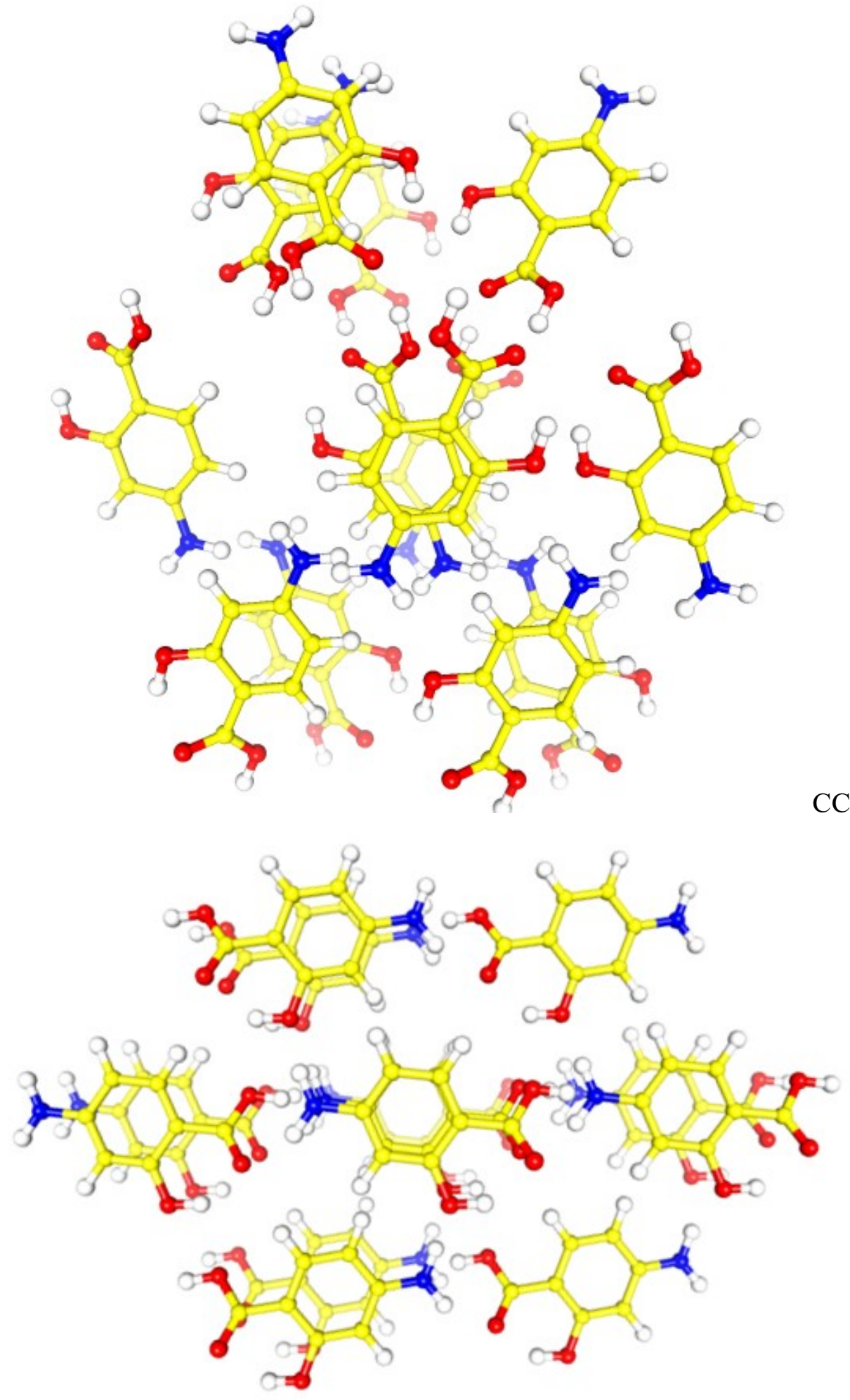

DA 

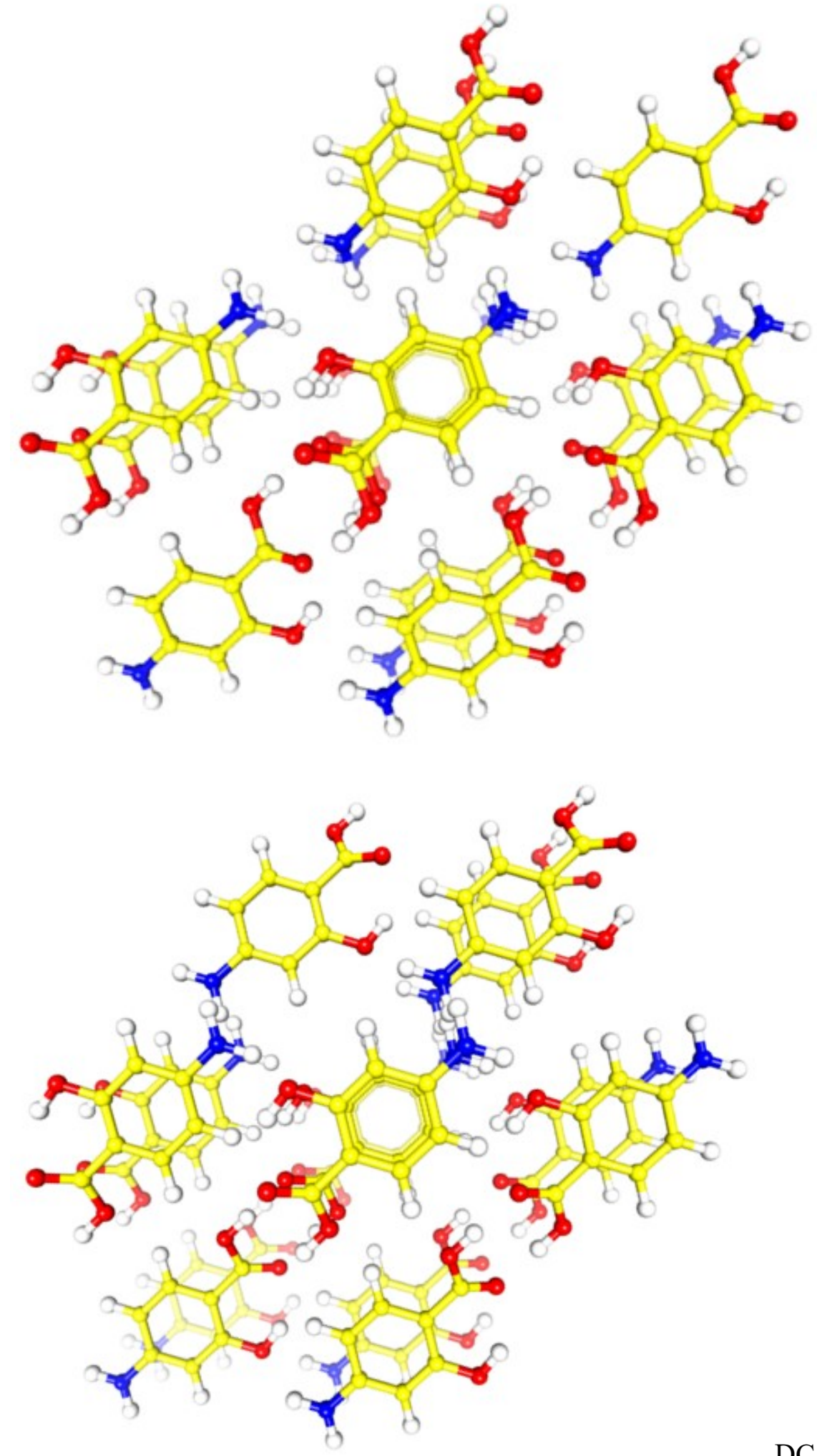

DC 


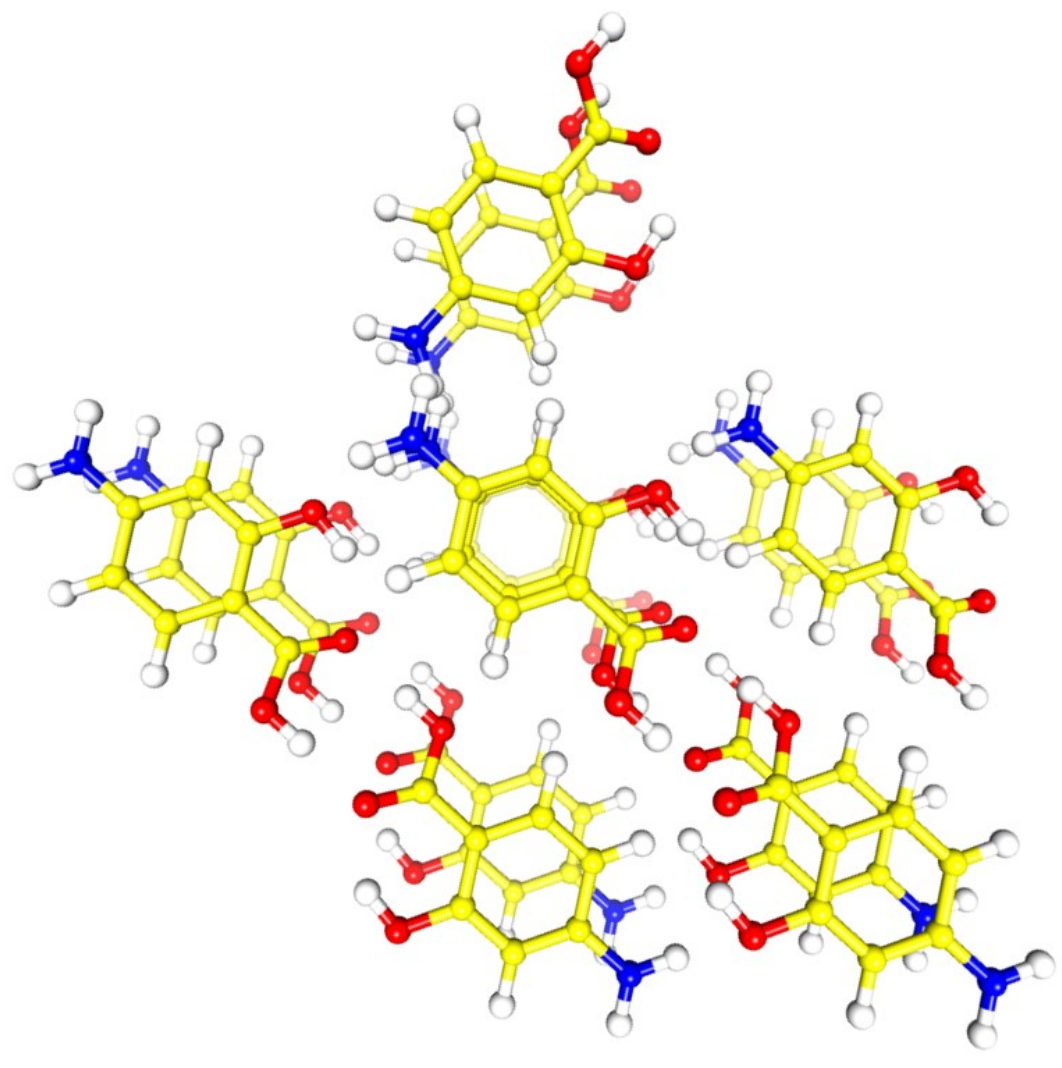

FA

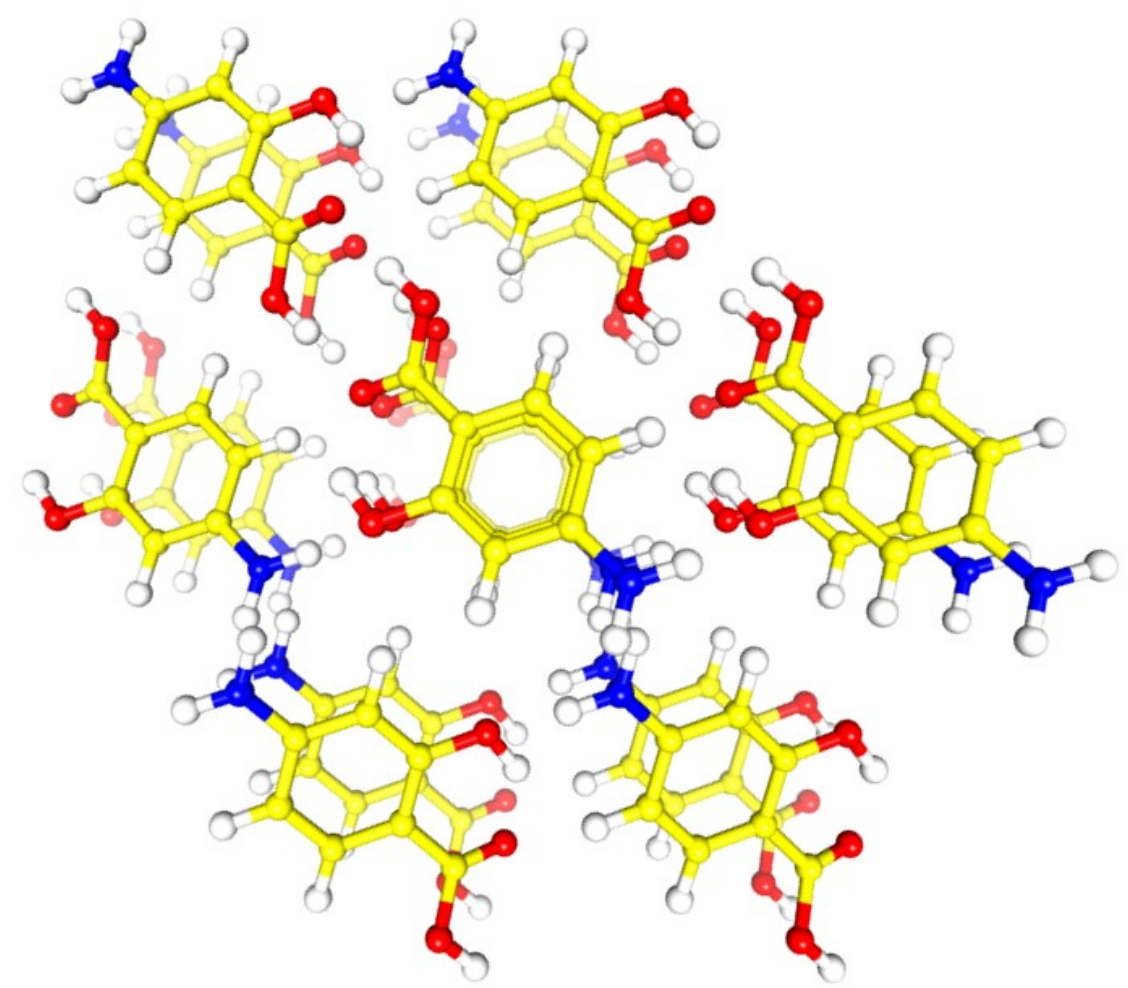

